GREAT INTERNATIONAL FISHERIES EXHIBITION. LONDON, 1883.

\title{
UNITED STATES OF AMERICA.
}

\section{D. \\ CATALOGUE Sectional Iibrory \\ OF THE \\ ECONOMIC MOLLUSCA \\ AND THE}

APPARATUS AND APPLIANCES USED IN THEIR CAPTURE AND PREPARATION FOR MARKET,

EXHIBITED BY THE

UNITED STATES NATIONAL MUSEUM.

BY

Lieut. FRANCIS WINSLOW, U. S. Navy.

WASHINGTON:

GOVERNMENT PRINTING OFFIOE.

1883. 

GREAT INTERNATIONAL FISHERIES EXHIBITION. LONDON, 1883.

\section{UNITED STATES OF AMERICA.}

\section{D.}

\section{CATALOGUE}

OF THE

\section{ECONOMIC MOLLUSCA}

AND THE

APPARATUS AND APPLIANCES USED IN THEIR CAPTURE AND PREPARATION FOR MARKET,

EXHIBITED BY THE

UNITED STATES NATIONAL MUSEUM.

BY

Lieut. FRANCIS WINSLOW, U. S. Narg.

WASHINGTON:

GOVERNMENT PRINTING OFFICE. 


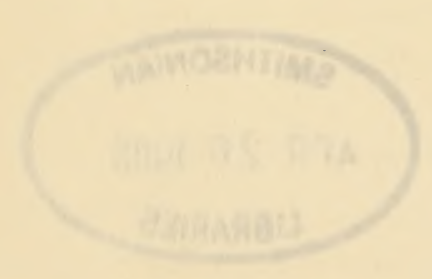


It is proposed to give, in the following pages, a brief account of the economic mollusea of the United States, together with a description of the manner of conducting the various fisheries and their dependent industries. Minute detail of matter, whether of biological or economic interest, is not attempted; the design is to supplement the molluscan exhibit by an explanatory pamphlet, which will be illustrated by the objects exhibited. The information given is obtained chiefly from Professor Verrill's papers on the Inrertebrates of Vineyard Sound, published in the Report of the United States Commissioner of Fish and Fisheries, and from the advance sheets of the Reports of Mr. Ernest Ingersoll on the Shell-Fish Industries of the United States, published by the Census Bureau. Many other authorities, too numerous to mention, have also been consulted.

The total annual product of the shell-fish industries of the United States amounts to $24,859,044$ bushels, valued at $\$ 14,629,187$. This total is divided among the various fisheries according to the following table:

\begin{tabular}{|c|c|c|}
\hline Name. & $\begin{array}{l}\text { Number } \\
\text { bushels. }\end{array}$ & Value. \\
\hline 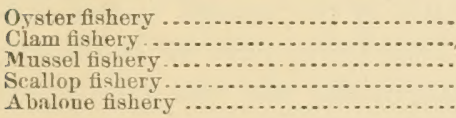 & $\begin{array}{r}22,195,370 \\
1,955,580 \\
600,000 \\
108,094 \\
\ldots . . . \%\end{array}$ & $\begin{array}{r}\$ 13,438,852 \\
996,305 \\
37,500 \\
28, \times 25 \\
127,705\end{array}$ \\
\hline
\end{tabular}

While the oyster industry, on account of its importance, deserves the most and first attention, yet, as the collection on exhibition is part of that of the National Museum, it is deemed best to maintain the original systematic arrangement, and therefore the most highly organized of the the mollusca, the Cephalopods are first considered.

\section{MOLLUSCA CEPHALOPODA.}

The most recent authorities assign thirty species of cephalopods to the fauna of the eastern coast of North America. While so numerously represented, however, only a few of the species are found in sufficient abundance to make them of commercial value. These comprise Ommastrephes illecebrosa, Loligo pealii, Loligo brevis, and the gigantic squids (Architeuthis) of Newfoundland and adjacent coasts; of these, the most abundant and widely distributed is 
Loligo pealii, Lesueur.

This is the common squid of the Atlantic coast of the United States; it is found from South Carolina to Cape Ann, Massachusetts, but is most abundant in Long Island and Vineyard Sounds. In depth it ranges from low-water mark to 50 fathoms; it is one of the Decapods or tenarmed class, of the Dibranchiata, or free-swimming cephalopods with but two branchiæ. As indicated by its classitication, it has ten arms, two of which are tentacular, club-shaped at the extremities, and longer than the other eight. In the male the left ventral arm is modified to subserve the peculiar reproductive process characteristic of the cephalopods, and under the head of the female is a horseshoe-shaped tubercle for the same purpose. In this, as in other species, the integument of the body is provided with numerous little sacs, containing pigment granules of different colors, and called cromatophores; by contracting and expanding these, the animal can change its color with great rapidity. Professor Verrill describes a male specimen of Loligo pealii as having the upper surface of body, head, and caudal fin eovered with rather large, circular cromatophores, but towards the margin of the fin and on the head the spots are smaller and less numerous, and the bluishwhite body color more perceptible. Over most of the dorsal surface the cromatophores are arranged in circular groups, the center being a large, round spot of dark purple; this is surrounded by a circle of ground color, a circle of cromatophores of lake-red and pink, and a deeper lying circle of pale canary-yellow ones. When expanded the cromatophores are light to dark red, varying to purplish-red and pink; when contracted they become small points of brownish-purple. On the lower side the cromatophores are thinly scattered, and the dominant color is the bluewhite of the body. The general appearance of the animal is reddishbrown. The arms are marked similarly to the lower part of the body; the eje is covered with a transparent membrane, and the pupils are brown or deep bluish-black. The body is somewhat elongated in form, and the caudal fin is long-rhomboidal, the outer angles obtusely rounded, and, in large specimens, its length is about two-thirds that of the body; when full grown the animal is from 6 inches to 1 foot long. The sexes are separated and reproduction is accomplished by means of the hectocotylized arm and horseshoe-shaped sucker. The spawning season lasts throughout the summer, but most of the eggs are laid in June and July. They are contained in long, gelatinous capsules, which are attached in clusters, often 6 and 8 inches in diameter, to seaweed, stones, and sbells, or other common support. Each capsule is from 2 to 3 inches long, and contains from 20 to 200 eggs. Like the other species, this is nocturnal and gregarious in its habits. The schools are usually composed of individuals of the same size and age; when this is not the case the larger and older squids have been observed actively engaged in destroying and devouring their smaller companions. They also prey upon many 
of the smaller fishes and crustaceans, and in turn are sought and eaten by the blue-fish, tautog, sea bass, striped bass, king-fish, and many other large market fishes, of whose food supply this squir forms an important item. It is also secured, when possible, by the fishermen along the coast and used for bait; but in this particular it is not so important as Ommastrephes illecebrosa; its range, not much north of Cape Cod, being more remote from the scene of the cod-fisheries. There are two varieties of the Loligo pealii; viz., borealis and pallida. In the former the only difference of much importance is the relatively smaller suckers. In the latter (var. pallida), the distinguishing characteristies are a shorter and stouter body, broader and larger caudai fin, and larger size of suck ers. It feeds, probably, upon the menhaden principally, and is, when adult, like Loligo pealii, food for large fishes, and when young is likewise devoured by numerous animals. The typical variety, Loligo pealii, is the only one exhibited.

\section{Ommastrephes illecebrosa, Verrill.}

This is the most common squid north of Cape Cod. It is abundant in Massachusetts Bay, the Bay of Fundy, and northward to Newfoundland. It is also found along the coast as far to the southward and westward as Newport, and in deep water as far south as Cape Hatteras. Its range in depth is probably as great if not greater than that of Loligo pealii it having been taken in 372 fathoms. It is known as the "shortfinned squid," the "sea arrow" and the "flying calamary" and, like the Loligo pealii, is one of the Decapods of the class Dibranchiata. The extreme length of the adults, from tail to tip of tentacular arms, is from 12 to 17 inches, and the length of the body from 7 to 10 inches. The body measures from 4 to $6 \frac{1}{2}$ inches in circumference. The caudal fin is transversely rhomboidal, or broad spear-shaped and is one-third wider than long. The anterior margins are courexly rounded, and the fin is generally shorter and broader than in Loligo. The general appearance is long and slender. In the male, either the right or left veutral arm is modified, or hectocotylized, for purposes of reproduction. The ground color is of bluish-white, with green, blue and yellow irridescence on the sides and lower surface. The whole body, head, outer surface of arms and fins are more or less covered with small, unequal, circular, orange-brown and dark-brown spots, which are continually contracting and expanding, the contraction darkening and the expansion lightening the colors. On the lower surfaces the spots, or cromatophores, are less erowded than on the upper surfaces, where they are frequently in different and partially overlaying planes. The suckers on the arms are pure white. The eyes are dark, blue-black, and are provided with lids. The changing tints are described by Professor Verrill as passing over the boly like a series of blushes. They usually appear in the water of a reddish-brown color or a pale, translncent bluish-white.

The reproductive process of this species has not yet been studied, nor 
as yet have we any definite information regarding the time, place, or manner of spawning. It is probable that they spawn in the open sea and that the eggs will be found floating at the surface. Neither has any information as to the length of time required to reach maturity been obtained, but it probably lives several years. This squid is an exceedingly active creature, moving in any direction, with great velocits, by means of the reaction of the ejected jet of water from the siphon or funnel. When darting rapidly, the lobes of the caudal fin are wrapped about the body and the arms are held closely, in an acute bundle, in front, the animal thus being sharp at both ends and passing throngh the water with the least resistance. They are predatory, gregarions, and nocturnal in habits, swimming mainly at night, in schools, and attacking and devouring small fishes and crustraceans, especially shrimp, herring, and young mackerel. They change their color and appear translucent and pale when in pur suit of prey; and when that pursuit is so active that the young fish disappear, the squid will sink to the bottom, assume the color of the sand, and thus ambuscaded will await the return of its rictim. They frequently, in their search for food, ground on the flats, and, as they pump ont water from the funuel with great force under such circumstances, thus throwing themselves higher on the beach or shoal, they perish in great numbers. At such times they also dis. charge their ink in great quantities. This squid, like Loligo pealii, is eagerly pursued by the cod and other voracious fishes, and while young an especial enemy is the full-grown mackerel. Also like the Loligo, it devours its own young.

The Ommastrephes is a very important item in the bait supply of the codfishery, fully half the bank fishermen using squids or cuttles as bait. Mr. Ingersoll states over 500 sail are engaged in capturing them for that purpose. They are taken, generally accidentally, in the pounds and wiers, and more frequently by seeking them on flats and beaches where they have been left stranded by gales or receding tides. They are also captured by using "jigs" or groups of hooks which are moved up and down in the water and to which the squids cling. Their nocturnal habits and tendency to gaze at a bright light are also taken advantage of, and the fishermen go out on dark nights with torches in their boats, and, as the squids swim backward, they are gradually driven ashore. On account of its availability for bait for the cod-fisheries, its abundance and the proximity of its range to the fishing banks, this is the most raluable of the Cephalopods of the American coast.

\section{Loligo brevis, Blainville.}

This is the common squid or calamary of the southern coast of the United States. It ranges northward to Delaware Bay, is common from South Carolina to Florida and is found also along the Gulf coast. It is a smaller, shorter-bodied species than Loligo pealii, has short rounded caudal fius, very short upper arms, and large chromatophoric spots. 
The body is short, thick, well rounded, and rather blunt posteriorly. The fins are broad and short, with posterior end very obtuse. The arms are all short, the two upper pairs being much shorter than the two lower. The tentacular arms have the "club" well developed. In the female there is no tuberele on the buccal membrane for attachment of spermatophores. The male has not been described, and consequently nothing is known of the methods, periods, or times of spawning. The adults are about 6 inches in total length, and sometimes larger. The chromatophores are large, of a dark purple color, and are regularly scattered on a pale ground-color. Above the eyes they are so closely crowded as to form dark blotches. The under side of the caudal fin is white. Though extensively distributed, this species is not very abundant, nor of much importance economically. It is used as bait, and is also sold as food in New Orleans markets.

\section{Arehiteuthis.}

\section{Giant Squids.}

These Squids frequent the waters of Newfoundland and the Newfoundland Banks, but apparently do not exist in great numbers, as Professor Verrill in his paper on the "Cephalopods of the Northeastern coast of America" mentions but twenty-six specimens of which he could obtain any definite knowledge. It is not unusual for them to be cast up on the Newfoundland beaehes after gales, and occasionally they are found dead or dying on the surface of the water in the neighborhood of the Banks. Verrill expresses the opinion that they inhabit the colder fiörds of Newfoundland, and are rarely seen at the surface unless disabled or incapacitated by disease from pursuing their customary life. So few specimens have been obtained for study and so seldom have these gigantic Squids been observed, that very little is known of their anatomy, or biography and still less of their sexual characteristics. All that is certain is that in many points they resemble the smaller species; that they swim by means of the jet of water from the funnel; that they have the ability to discharge large quantities of "sepia" or "ink," and that they are probably carnivorous. Whenever found they are used for bait, for dog-food and as manure.

The model exhibited is of a specimen of Architeuthis princeps, Verrill, cast ashore on the coast of Newfoundland in 1877. It is not the largest specimen that has been seen, but was the one most perfectly preserved when it reached the hands of scientific observers.

Octopus punctatus, Gabb.

\section{Octopus, or Devil Fish.}

This species exists on the northwest coast of the United States, and attains a large size, being probably the largest species of Octopus in 
existence. Very little is known of it, though as a bait it is of considerable importance in the cod-fishery at the Shumagin Islands. The flesh is also eaten by the Indians.

In addition to this species there are several species of squids on the west coast that are occasionally eaten by the Chinese, especially one allied to Ommastrephes. The flesh is dried and exported to China, but the industry is not of sufficient importance to justify particular mention.

\section{Th ollusca encephala.}

\section{GASTEROPODA.}

Like the Cephalopoda, the Gasteropoda of the American coast, while very numerously represented, are not of much importance economically. The abundance of more palatable, bivalve shell.fish, such as the oysters and clams, has prevented the univalves, even when edible, from receiving much attention. Doubtless many species, especially those of large size, like the Fulgur carica and Buccinum undatum, have been eaten in the past by the Indians and, indeed, the shell-heaps along the coast contain evidence of such having been the case; but in recent times the appropriation of this class of mollusks to the uses of man, with the exception of the genus Haliotis, has been so slight that it is impossible to obtain any statistics bearing upon the subject. A number of the Gasteropods have been eatalogued as used for food or bait; but, with the exception above noted, they form a possible rather than a real food supply. Even their consumption as bait is inconsiderable, and nowhere is their pursuit reduced to any systematic or organized method. As, however, many of the Gasteropods are carnivorous and predatory, doing, at times, much damage to oyster beds and destroying numbers of other valuable mollusks, they become of consequence in any consideration of shell-fisheries and in their destructive relation they will be noticed in detail.

\section{Buccinum undatum, Linné.}

This animal is known, generally, as one of the "sea-snails," and sometimes as the "whelk." It has not a rery wide distribution on the American coast, being uncommon south of Cape Cod, except in deep water. It is common in Massachusetts Bay and abundant further north, to the coast of Greenland. As a fossil jt is common in the PostPliocene deposits of Maine, Canada, and Labrador. Though the ordinary American specimens, from shallow water, differ considerably from the European types, yet, as it is not difficult to form connecting series, and as the deep-water specimens differ very little from the European form, Professor Verrill decides that the two species are identical. This Gasteropod is available for food; but, though probably eaten by the Indians, is not at present sought, except occasionally as bait. It usually inhabits rocky bottoms, but is occasionally found elsewhere. 
Littorina littorea (Linné), Menké.

\section{PENNTIVINTKE.}

This species is not an inligenous one, having heen introluced from Europe, probabiy with ballast, during the last fifteen or twenty years. It first appeared on the coast of Maine in 1w6s, and since then has spread gradnally to more sonthern waters. In 182.2 it was seren in the vicinity of Proviucetown, Mass. In 1875 it was seen at Wool's Holl, hut was abundant at Provincetown; and in 1880 had become abmulant at Wood's Holl. It is now found as far west as Stonington, Conn. Though not used as food it is available for that purpose.

\section{Ilyanassa obsoleta, Stimpson.}

This small univalve has no distinetive common name, and goes by the general term of "sea-snail." It is found ou the "ntire dastern and sonthern coasts of the United States, though not aliundant sonth of Cape Cod, and is local in the Gulf of Saint Lawrence. It is fonnd fossil in the Post-Pliocene of Matssichnsetts, Nantmetet Island, Tirginia, and South Carolina. The Ilyenesse obsoletn is, probably, the most abundant Gasteropod of the Ameriean coast. While it is naturally an inhabitant of muddy bottoms and flats, yet it lives and flourishes om sandy shores, among eel-grass, and on the piles and timbers of wharves equally well. It is fombl alike, far np estuaries and on the open const and its crooked trail and burrows can be observed on exery beach and shore. As the tide leaves the mud flats the animals are seen in immense numbers, especially in and about the pools. They perform the useful duty of scavengers, and are also sought and used for bait; but are not considered edible.

\section{FIALIOTIDF.}

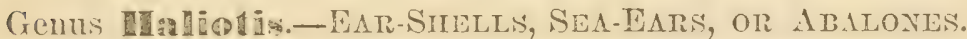

There are four species of Inuliot is that are of commereial importance: The "White Sea-Ear," or Iluliotis crucherontii; the "Splendid Sea-Ear," or Ifuliotis splendens; the "Tongh Sear.Ear," or Hulioti: corrugete; and

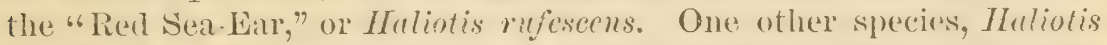
Riamchatlene, is found on the coast of Alaska, hut is rare. These Gasteropods are distributed along the whole North Pareific coast from San Franciseo to the sonthward, inchuling the peuinsula of Lower California, thongh they decrease in abundance in the region of Cape Saint Lucas. They are also found in the Gulf of California, and along the Mexican coast. The "White Sea-Lar" (Indiofis cracherodii) is the most abundant, and is the one generally known in commeree. The "Splendid" and "Rough" species (Huliotis splendens and Haliotis corrugutu) are most abundant in the neighborhood of San Diego. The shell of Ilaliotis 
rufescens was the one principally nsed by the Indians in maling their sliell money, but is now rare and is usually found to the northward of San Diegon. All the species are known on the coast as "Abalones," a name originated by the Spanish-Americans.

The Abalones dwell mpon weed-grown rocks, and feed upon marine alyee. They have a broad, flat, muscular foot, arlapted rather for Lolding than for locomotion, by which they eling to the rockis with great tenacity. Throngh the small, circular holes, near the margin of the shell, the animal, when clinging to its support, receives its supply of oxjgen and, by means of the small tentacles which protrule through them, is warned of the approach of danger. No species of the genus IInliotis are found on the astern coast of the United States, but on the western coast the trate in both shells and flesh is of considerable value.

The fisbery is carried on mainly by the Chinese inhabitants, who preserve and eat the flesh, which is said to be nutritions but indigestible. The mothor of preserving is tho simple one of drying and salting, after which the major portion of the crop is exported to China. It is estimated that about six toms of living animals must be gathered to obtain one ton of flesh, and as there were some $3 S 5$ tons of meats gathered in 1879-s0, that amount indicates that nearly 2,400 tons of living Abalones were taken during the season. The fishery has of late years become so severe that the coast of California has been swept and the fishermen are compelled to resort to the islands lying off the peninsula. The usual methor is for Americans to supply the necessary eapital and transportation to the islands and the Chinese fishermen to do the work, the former taking the shells and the latter the flesh obtained from the season's fishery. The tenacity with which the animal clings to the rocks by means of its museular foot is so great that it is not always easy to remove it. Several methods are used ; a trowel or spate is employed, usmally, to slip) under the animal and so dislodge it; and another method, not so generally used, is to pour hot water over them and then push them suddenly adrift with the foot.

The fishery is, howerer, not very laborious and in no way hazardous. The animals live but a little below low-water mark, and the islands and coasts on which they are at present found are remarkable for equability of climate. The growing scarcity of the animals alone prerents the fishery from assuming greater importance. The shells are exported in large numbers to Europe, and are there used in various ways. $\Lambda$ smaller number are retained and used in oruamental manufactures in this country.

The value of the fishery for the year 1879 was:

Value.

Meats, 777,600 pounds........................ $\$ 38,800$

Shells, $3,833,500$ pounds....................... 85,825

Total .............................. 127,6 


\section{Fulgur carica, Conrad.}

This species is found along the eastern coast of the United States from Florida to Cape Coll. It is abundant in Vineyard and Long Island Sonnds, in from 1 to 10 fathoms. It oceurs in the Vincene formation of Marylank, and in the P'ost-Pliocene of Virginia, North and South Carolina, and Florida.

\section{Sycotypus canaliculatus, Gill.}

This is foumd on the eastern coast of the United States from Florida to Cape Cod, also on the west coast of Florida and the northern shores of the Gulf of Mexico. It is alumblant in Vineyard and Isurg Island Sounds, in from 1 to 8 fathoms of water. It occurs in the Post-I'liocene of Virginia, North and Sontlı Carolina and Northern Florida, and in the Miocene of Maryland and Virginia.

As these species generally exist in compauy, and in habits have a close redationship, they are considered together, though the former is found in greater abundance in more sonthern waters than the latter, and has struetural and other distinguishing peeuliarities. Both species are occasionally found on sandy thats and in tide pools, especially during the slawning season, but they gencrally live in deeper water and oft shore. They are found, also, on rocky shores hut usually are met with on gravelly and shelly botoms, where they find a larger amount of sustenance. These large shells are readily recognized by the fishermen and inhabitants of the coast, who have assigned them rarious designations. On the borders of Long Island Sound and Long Island they are callerl indiseriminately "Perivinkles"; while on the coast of New Jersey this is abbreviated to "Winkle," or "orrupterl into "Wrinkle" The syleotypus cenulienlutus is also called the "Mairy Whelk," a designation dne to jts hairy epidermis. This speceses varies in color very mueh, and may be found of a light orange or livid brown. The Fulgur carica also varies with advancing age or with the climate.

The exgs of both species are deposited in eapsules, which are strung together iu strings freaguently a foot or more in length. Each calpsule contains some twenty or more egas, and from fifty to one hundred capsules are found in a string. There ar. market differences in the chatrater of the eapsules of each species by which they may be distinguished; that of $F$. carica being smaller, thicker, and having truncate exlges; whiles. cunaliculatus has larger, thimer eapsules, with a thin, sharp, outer edge and radiating ribs on the sides; but both are peculiar and will be readily recognized after inspection of the specinens exhibited. As both the Fulgur and sycotypus are predatory and carnivorous, destroying by means of the teeth on the lingnal ribbon any unfortunate biralve they may meet; as they are especially enemies of the oyster and clam; and as they are in the present day of little or no use to man, both they and their curious egg-cases had best be destroyed whenever met. 


\section{Urosalpinx cinerea, Stimpson.}

This is the "Drill" or "Rough Whelk," and is abundant along the whole eastem coastis of the United States from Massachusetts Bay to Florida. It is also found on the rest coast of Florida and in the wulf of Mexico. It is more rare and local north of Massachusefts Bay, but extends to the Gulf of Silint Lawrence. It oceurs in the Post-Plineene deposits of Massachusetts, Nantucliet, Virginia, North and South Carolina, in the Pliocene of South Carolina, and Miocene of Maryland.

\section{Purpura lapillus, Lamarck.}

The shell of this animal resembles somewhat that of the preceding species, and tho animal itself has similar carnivorous habits, but is at more aretic type, livine in the colder waters north of Cape Cod and inhabiting exposed rocky headlands, while the $U$. cinerea is fonnd at all joints. The Purpara lapillus is extremely abmolant on the coasts of Maine and Nova Seotia, and extends to Long Island Somd. It has been fomm in the P'ost Pliocene of Maine, but is not a common fossil.

The Lrosalpine cincrea is nore abmolant in hasckish water and on shelly bottoms than elsewhere, bnt is fomm indiscriminately wherever there is suitable food. The Purpura lapillus, thongh like the "Drill," a borer, ennfines it sell to the barnacles growing on the rocks; but the Trosalpinx is much more harmful and is an inveterate enemy of the oyster, boling, hy means of the sharp, tlinty teeth that cover its tongue, rouml holes thromoh the oystershell and sucking ont the contents. It is particulary destructive to young oysters in Chesapealie bay, and a shell has heen observed having fifty-fom young attached to it, of which fifty had heen destroy ed hy the "Drill." On some of the beds fully 50

per cent. of the yomms penish from this anse. It is probalble that the

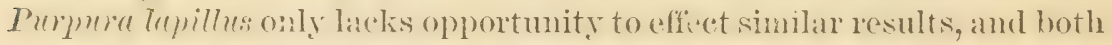
the animals and their comions vase-shaped exg-apsules, attateded to stones and roeks by a short stalk, should be destroged whenerer met.

\section{Lunatia heros, Adams.}

Is fomnd from Georeria to the Gulf of Saint Lawrence. It is abmurlant on the coast of New Jelsey and sonthern eoast of Lomg Istand from low water to 10 fithoms. Oecurs in the Miocene formation of Maryland, Virginia, and sonth Carolina, in the Pliocene of Sonth Carolina, and in the I'ost Pliocene of Camada and South Carolina.

\section{Neverita duplicata, Stimpson.}

Fxists on the eastern coast of the United States fiom Morida to Massachusetts bay, and on the northern and western shores of the (iulf of Mexior). It is ahmolant from Lons Istand sound southwarl, and is foumd as a fossil in the Miocene and I'ost Pliocene deposits of Viresinia, North and South Carolina, in the Miocene of Maryland, and in the Plio- 
cene of Sonth Carolina. Like the F. carica and S. comaliculatus, Lunation heros and Neverite duplicata are generally found in company; having the same labbits and appearance, to the casual observer, they are frequently eonfounded one with the ofler, and are nsually linown to the fishermen and long-shenemen as "Sea-Suats," and sometines as " Winkles"s or "Periwinkles." On areomnt of their similarity in distribution and close relationship in habits, they are considered together.

The Lunatia heros is found on. neally all sandy shores, in pure water, and apparently prefers the open coast and heary surf, wrowing mule: those conditions to a linger size than elsewhere. It is by no menins as large as the Fulgur or sycotymus, but has been linown to reageh five inches in length by nearly four in brearlh. When in motion the tout and soft parts of the body are protruded to a remarkable extent, and spread out so broadly as to almost conceal the shell. The fout is lancee, concave below when expanderl, and when extended beneath the sian aflords the animal a secure anchor or hold; it is the organ by which the animal burrows for protection or prey. Both the Lumtire heros and the Tereritu duplicuta are destructive, boring round holes throush hivalve shells by means of small teeth on the lingual ribbon, and then sucking out the contents of the shells. Tor lo they contine their operations to the bivalves, but attack mivalves, not exeepting their om romng, as well. Nererita duplicete difters firom its nsual associate in being found less frequently on the outer beaches and wrowing more abuudantly, though not to so large a size, elsewhere. It is a more southern species than the Lmeatia heros, and is not common north of Cape Cod. The esgeg cases of both speces are often met on mud and samb flats at low water, and are very curious. They comsist of a boarl, thin ribhon of sand, coiled in a circle. The ribbon is composed of inmumerable little cells, each containing eggs, and smounded hy fine sand cementer together by muens. The cells can rasily be seen by holding the ribbon to the light, and for the same reason given for destroying the ergo-capsules of the Fulgur and sycotypus, these egg-cases should meet a similar fate when enconntered.

While both $L$. heves and $X$. Auplicate are found on sandy and gravelly shores, their natural swound, where they exist in greatest abundance, is the shelly bottoms of oyster beds and similar areas.

\section{Crepidula plana, Say.}

\section{Crepidula fornicata, Lamarck.}

These two species are neither directly nseful nor ham ful, but when present in large numbers they form one of the indications of the health of an oyster-bed and are therefore exhibited. The former is linown as the "Sipprer-Shell" and the latter as the "Boat-Shell." Bothare foumel from Massachusetts to Florida, and on the northern shores of the Gulf of Mexico. 


\section{Ostrea virginica, Gmelin.}

This, the most important mollusk of American waters, is known also as Ostrea virginiana, Lister, Ostrea borealis, Lamarck, and Ostrea canaden. sis, Bruguiere. It is the common American opster, and the many varions forms of shell net along the coast are due to local and peculiar conditions, and are by no means constant either in the locality or shell itself; nor is there any structural difference in shell or body in any of the varieties which have receivel specific names. This is shown by the series illustrating the variations of Ostrea boredis and Ostrea virginice. The specimens in this series are from all parts of the coast, and in some of them the change from one form to the other and back is very matied. The series of specinens illustrating the peculiarities of the dillorent species, Ostrue virginicu, O. borealis, O. luridu, and $O$. edulis, will afford the observer a means of compring the dissimilarities which exist between well-defined species, such as the virginicu, luridu, and edulis, with those existing between $O$. virginica and $O$. borcalis, which are only nominal varieties.

Oysters are found aloug the entire east and rest coasts of the United States with the exception of the lower part of the peninsula of Floridat and the coast of Maine. Their absence from the southern waters of Florida is due probably to the absence of fresh-water streams; and their disappearance from the coast of Maine, where the shell-heaps testify to their existence in large numbers in the past, is the result of climatic changes, compled, most likely, with the inordinate fishery of the aborigines. The shells are found, fossil, in the Post.Pliocene leposits of Massachusetts, Nantucket, and Gardiner's Island, in the Pliocene of South Carolina, and in the Miocene of Virginia and Sonth Carolina. The distribution of this species will be best understood and appreciated by viewing the charts, showing the areas and positions of the beds. The most noticeable feature about them is the contrast between the cultivated areas of the Northern and Southern States.

BIOLOGY.

It was long supposed that the American oyster resembled the European species (Ostrea edulis and other varieties) in its methorl of reproduction and sexual characters; and on that aceount no attempts were made to adapt to the oyster the methods of artifial impregnation. In 1879, however, Dr. W. K. İrooks made the initial experiments and proved the possibility of impregnating the eggs and maintaining the embryos alive for some time, withont the aid of the parents. The experiments were so interesting and important, that Dr. Broolis' description of the manner of condueting them is here reproduced:

"BREEDING IIABITS OF TIE AMERICAN OYSTER.

"Our knowledge of the development of the oyster is derived from the fragmentary observations of various German, French, English, and Lus- 
sian embryologists, whose work will be noticed at length farther on. While the subject has received the attention of a number of observers, no one has been able to get anything like a complete series of the early stages of derelopment, and I approached my work without hope of accomplishing much of purely seientific value, although I dirl expect to obtain some information as to the time and conditions of spawning, aud other questions of economic interest. My uncertainty of suceess was increased by the total failure of an attempt which I had made the summer before.

"All the published papers upon the subject state that the eggs are fertilized inside the body of the parent, and that the young are earried inside the parent shell until they are quite well advanced in development, and provided with shells of their own; that they swim abont after they are diseharged from the parent until they find a place to attach themselves, but that they undergo no change of structure between the time when they leave the parent and the time when they become fixed. Misled by these statements, which are not true with our species, I opened numbers of oysters during the summer of 1868 , and carefully examined the contents of the gills and mantle chambers, but found no young oysters. I concluded that the time during which the young are carried by the parent must be so short that I had missed it, and I entered upon the work this season with the determination to exanine adult oysters every day through the breeding season in seareh of young, and at the same time try to raise the joung for myself by artificially fertilizing the eggs after I had removed them from the body of the parent.

"I met with complete suecess with the second method from the begiuing, and suceeded in raising countless millions of young oysters, and in tracing them through all their stages of development unt il they had acquired all the characteristies which the European embryologists hare described and figured in the young of the European oyster at the time it leaves its parent to become fixed for life.

"I reached Crisfield on the 19th of May, and established myself about three miles from the town aud about half a mile from Pokamoke Sound, and on Monday, the 21st, I opened a dozen fresh oysters, and found three females with their ovaries filled with ripe ova, and one male with ripe spermatozoa.

"I mixed the contents of the reproductive organs of these four oysters, and within two hours after the commencement of my first experiment, I learned by the microscope that the attempt at artificial fertilization was suecessful, and that nearly all of my eggs had started on their long path torrards the adult form.

"I mate careful microseopic examination of the gills and mantles of all these oysters, but neither at this time nor afterwards did I find any fertilized eggs or young inside the parent shell, althongh I examined more than a thousand adults during the season. During the summer I found females with the oraries so distend ed with ripe eggs that, they 
were oozing from the openings of the oviducts; others where the oraries were half emptied, and other's which hat discharged almost all their egess, and others at all the intermediate stages, but in $n o$ case did I find a single developing egg iusicle the shell of the parent.

\section{"ARTIFICIAL IMPREGNATION OF THE OXSTER EGGS.}

"If a number of oysters are opened during the breeding season, a few will he found with the reproductive organ greatly distended and of an uniform pure opaque white color. These are oysters which are spawning or nearly ready to spawn.

"If the point of a knife be pushed into the reproductive organ a milklike fluid will ooze ont of the cut, and a little of it may be taken up on a linife blate and transfered to a glass slide for examination. The drop of thid should be thoroughly mixed with a drop of sea water and placed on the slide, and gently covered with a cover-glass, and examined with a magnifying power of about one hundred diameters. If the specimen is a female, this power will show that the white fluid is almost entirely mate up of irregular pear-shaped ovarian eggs (Fig. 49), each of which contains a large circular transparent germinative resicle surrounded by a layer of granular slightly opaque yolk. It is almost impossible to describe the slight differences which distinguish the perfectly ripe egg from those which are nearly ripe but not capable of fertilization, although a very little experience will enable one to tell whether it is worth while to attempt the fertilization of the eggs of any given female.

"When the drop of thuid is thoronghly mixed with the sea water, the exgs should appear clean, sharply defined, separate from dach other, and pretty uniformly distributed through the drop, as shown in the tigure. If they adhere to each other, or if their outlines are indistinct, or if their is much incr granular matter seattered between the eggs, it is probable that the aitempt at artificial fertilization will at best be only partially successful.

"When a pretetly ripe female is found, it should be set aside and the search continued for a male. The question of the sex of the oyster has long been a matter of dispute, and the suloject will be fully dis"ussed in another place. All that concerns ns now is to know that for all practical purposes the sexes are separate in the European as well as the American oyster. At the breeding season each individual is either exchusively a male or exclusively a female. Out of several thousand which I examined, I have not found one which contained both egess and male cells, and all the best authorities upon the European oyster make the same statement, although there is some reason for the belief that an oyster may gire rise to eggs one season and to male cells another year. When a drop of the milky fluid from a ripe male is mixed with a little sea water and examined with a magnifying power of one humdred diameters, it is seen at a glance to be quite different from the fluid of a female. There are no large bodies like the eggs, but the fluid is 
filled with innumerable numbers of minnte granules (Fig. 48), which are so small that they are barely visible when matenified one huncherl dianeters. They are not uniformly distributed, but are mulh more numerous at some points than at others, and for this reason the thid has a cloudy or cordled appearance. by selecting a place where the gramules are few and pretty well scattered, very careful watehing will show that each of them has a lively daneing motion, and examination with a power of five humbed diameters will show that each of them is tadpole shaped (Fig. 50), and consists of a small, oval, sharply defined ' leath' and a long, delicate 'tail,' by the lashiugr of which the dancing is produced.

"It is more dificult to decide whether the male eells are perfertly ripe than it is to deecile in the eatse of the egass. With a magnifying power' of fire humbed diameters, each 'head' should have a char, well marked outline, aus. they should be rery uniform in size, and separated from eatch other, as in Fig. ot). Cuder very farorable circumstaneses this power should also show the 'tails' as very faint undulating lines.

"If the 'heads' vary much in size, or if they are aggregated into bunches, with the 'tails' ratliating from the bunches in all directions, or it there is much gramular matter so small that the outlines of the particles are not visible when magnified five hundred dianceters, the fluid is not perfectly ripe, and fertilization with it will not in all probability be very successful.

\section{"NUIBER OF EGGS.}

"As the male cells are infuitely more numerons than the exgs, the ripe fluid from eren one small male is enongh to fertilize all the "ags: of five or six large females.

"The number of male cells which a single male will yield is great beyoul all power of expression, but the number of exos which an arerage female will fumish may be estimated with suficient exactness. A single ripe egg measures about one five-hundredth of an inch in dianeter, or five hundred laid in a row, touching each other, wouk make one incls; and a square inch would contain five hundresl such rows, or $500 \times 500=250,000)$ eggss. Nearly all the eggs of a perfextly ripe female may be washed out of the orary into a beaker of seal water. and as they are hearier than the sea water, they soon sink to the bottom, and the eggs of a meelium sized female will cover the bottom of a beaker two inches in diameter with a layer of egags one-twentieth of ail incle deepe. The area of the bottom of a beaker two inches in diameter is a lithe more than three sculare inches, and a layer of ergess one-trentieth of an inch deep, corering three square inches, is equal to one three-twentieths of an inch deep and tro square, and as a single layer of eggs is one fivelnundredth of an inch thick, a layer threes-twentieths of an inch thick will contain seventy-five liryer's of eggs, with 250,000 eggs in each lap̧er, or $18,7 \pi 0,000$ exgs. It is dificult to get the eggs, perfictly pure, and if 
we allow one-half for foreign matter and errors of measurement, and for imperfect contact between the eggs, we shall hare more than nine millions as the number of egas laid by an orster of arerage size, a number which is probably less than the true number.

"Mobbius estiusates the number of eggs laid by an average Furopean oyster at 1,012,925, or on!y one-ninth the number laid by an ordinary Americun oyster, but the American oyster is very much larger than the Enropean, while its egres are less than one-third as large, so the want of acreenent betwen these estimates does not indicate that either of them is incorrect.* Another estimate of the mumber of exgs laid by the Enropean ogster is given loy Eyton (History of the Oyster and

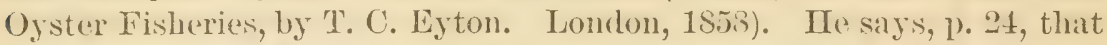
there are about 1,800,000, and therefore agrees pretty closely with Möbius.

"An unusually large American oyster will yield nearly a cubic inch of engs, and if these were all in absolute contact with each other, and there were $n 0$ portions of the oraries or other organs mixesl with them, the cubic inch would contain $500^{3}$, or $125,000,000$. Dividing this, as before, by two, to allow for foreign matter, interspaces, and errors of moasurement, we have about $60,000,000$ as the possible number of egrgs from a single oyster.

"Although each male contains enough fluid to fertilize the eggs of several females, there does not seem to be much diflerenes in the num. ber of individuals of the two sexes. When a dozen oysters are opened and examined there may be fire or six ripe females and no males, but in another case a dozen oysters may furnish several ripe males but no fimales, and in the long run the sexes seem to be abont equally numerons. Oystermen believe that the male may be distinguished from the female by certain ehancteristics, such as the presence of black pigment in the mantle, but microseopic examination shows that these marlis have no such meaning, and that there are no differences between the sexes except the microscopic ones. It is not necessary to nse the wicroscope in every case, however, for a little experience will enable a sharp observer to recognize a ripe female withont the microseope. If a little of the milliy fluid from the ovary of a female with ripe or nearly ripe exgs, to be taken upon the point of a clean, bright knife-blade, and allowerl to flow orer it in a thin film, a sharp eye can basely detect the (xyses as white dots, while the male fluid alpuear's perfectly homogencous under the same circumstances, as do the contents of the ovary of an immature female, or one which has finished spawning. Tithen the eggs are mixed with a drop of water, they can be diflused throngh it without difliculty, while the male flud is more adhesive and dillicult to mix

* "Möbins' measurement, from 15 to 18 millimeters, is given (Austern und Austernwirtschaft, 1877), as the diameter, not of the egg, but of the embryo, but his figures show that the European oyster, like the American, does not grow much during the early stages of development, but remains of about the same size as the egg." 
with the water. By these indieations, I was able in nearly erery case to judge of the sex of the oyster before I had made use of the microscope.

"Iu order to fertilize the egess, all that is necessary is the mixture of the ripe exgs with a little of the ripe male fluid in a drop of water. If the point of a knife-blate be dipped in the fluid from a female and tomelere to a glass slisle, and then dipped into the flud of a male, and forched to the same part of the slide, and a diop of sea water bes adrled, to catuse the two to meet, most of the esgs will be fertilizerl, and their (ally stages of development can be studied in a single drop of water, but to secure the fertilization and healthy derelopment of large numleres of eggs, several precantions are necessary, as well as a few instruments and pieces of apparatus.

"The following is a list of the things neeled for procuring, fertilizinn, and hatching the eggs: A pair of sharp-pointerl scissors ; a par of small forceps; half a dozen watch erystals; a set of about half a lozen Elass bealiers, or tumblers, of different sizes, from lialf a pint up to half a gallon; two or three dipping tubes, or glass tubes six or aight inches long, open at both ends, hut with one end drawn ont to a fine point; a small glass or rubber siphon for drawing the water out of the bealiers. For tracing the development of the egess, a microserpe, magnifying at least one hundred diameters, and half a dozen glass slides and thin glass covers are wanted.

"After the oysters have been opened, and at least one ripe male and one ripe female found, cut off the mantle lobes and gills of the male with the seissors, close to the visceral mass, and tear them ont with the forceps and throw them away. C'ut around the addurtor muscle with the scissors, so that the viseeral mass may be lifted ont of the shell and transfered to a small sameer or to a watch crystal. Molding the vis(epal mass with the forenos, cut ont with the seissors as much as possible of the digestive organs and liver and throw them away, and then (hop n1) the reproductive organs with the scissors, picking ont and thowing atray any fuameuts of the liver, digestive oregans, mantle or wills which may puesent themselves. In order to have the young oyster thive, the water must be liept free from framents of the various orgaus of the adult, as these would soon decar and destroy the emliryos, and it is therefore important to remove them as rompletely as possible. After the mass has heen ehopped up as fine as possible, fill up the wateh crystal with fresh sea water, stir it up, and then allow it to run into one of the smallest healeres, whel has becen nearly filled with sea water. As the water runs out of the watch crgstal, be eareful to allow as few of the fragments as possible to rum with it."

" Now till up the wateh erystal with water again, and stir and pour ofl as hefore, and repreat the process until nearly all of the male fluid has bren washed ont of the fingments and poured into the bealier. Stir the contents of the bealier for a short time, and then allow it to stand 
alout firc minutes, to allow any fiagnents to settle to the bottom, then jom the fluid, which should be quite milky, into another small bealer, leaving behind, to be thrown away, any particles which may have settled to the bottom. The male eells retain their full vitality ion sereral homs after they have been mixed with seat water, so the beaker may be

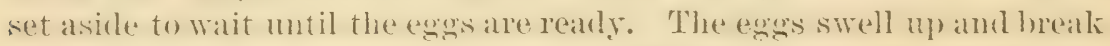
to pieces within a rery fer mintes after they are mixed with water, muless they are fertilized at once, so it is much better to arld the exas to a freviomsty prepared mixture of male cells and water than it is to put the eggse into the water to wait until the male fluid is got rearly.

"Taking now one of the lemales, remove and (ehop up the ovary in the same way in another watch crystal, observing the sabe preseations in removing all portions of the body. Fill the wateh glass with water, anci stir and pour off into the beaker as before, giving the contents of the healier a good stirring atter each lot of egage is adcled, in oreler to diftuse them through the water at once, and thus insure the spreedy contact of each of them with some of the male cells.

- Fill the "rystal with water again, and stir and pour ofit, and repeat until all the esess have been washed ont of the flatements of the ovary."

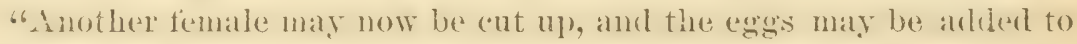
the contents of the same bealine; but if the females are lange, and yiehl many exas, it is mot best to nse more than one, for althongh there are enomph male cells to fertilize a very great number of egass, the egens are hearier than water and soon sink to the ho tom, and if they form a rery thick layer, only those which lie near the surface hare room to develop.

whor bealier shomld now be allower to stand for about ten minutes, ancl in the mean time some of the esges mat he pieked out with a dip). ping tube, for examination moler the micuserope. In using the dippongtule, cover the lange end with the tip of the finger, and run the small end down chose to the bottom of the beakex, ank then take the fingere oft the fop, and as the water rums in at the bottom it will can'ry some of the exs. with it. When the tube is filled, place the finger on the top again, and draw it ont of the water, and, holding it perpendieularly on the ("enter of a shass slicle, and taking the finger off the top), allow a good-sized drop to run out into the slide.

"If things ard working properly, each org should now have a number of male cells attahed by their hearls to it: outer surface, with their tails radiating from it in all directions, as shown in Fig. 51.

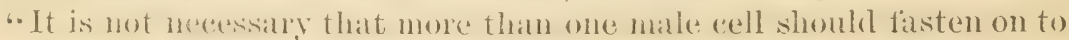

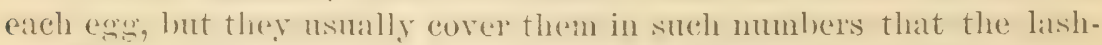
ing of their tails anduses the exos to rotate and move through the water.

". Is soun as all the exses have male cells attached to them, it is neces-

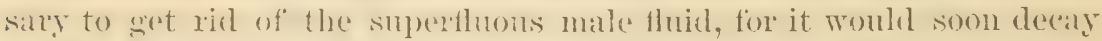
and pollute the water if it wore allowerl to reman, and if it is not drawn off from the egas while they are at the luttom, it is almost inpossible 
to remore it after the embryos have begun to swim, withont loosing them as well.

"After a final stirring, the heaker should be allowerl to stand for about five minutes, to allow the exys to set tle to the botom, and the fluid above them should then he drawn off through a siphon, reaching nearly but not quite down to the egers. A fresh supply of sea-isater should then be adfled, and the egons stirred and allowed to settle, and the water drawn oft as before; and this should be repeated until the water, after the eggs have settled to the bottom, remains clear.

"The beaker may now be set aside where it will not be exposed to sudden changes of temperature, and the egos will require no further attention until the enhryos begin to stim, which will be in from two to six hours, aceording to the temperature. The little gyster's must of conrse be supplied with fresh sea-water from time to time during their development, and as they are so small that the water cammot be drawn off after they hegin to swim, they must be supplianl with fieshe water ly transferring them from time to time to langer and larger heakers. In two hours or so after the esins are fertilized the embrgos begin to swim, and erowd to the surface of the water in great numbers, and form a thin stratum close to the surfice. This layer of embryos may bet ("arefully siphonerl off into a rery small beaker, and a little fresh seawater added. In an hour or so there will be a new layer of embryos at the surface of beaker No. 1, and these shouk also be siplened into No. 2, and this should be repeated as long as the embryos continne to rise to the surface of the first beaker. Every five or six hours a little fresh sea-water shonld be poured from a height of a foot or more into beaker Yo. 2, until it is filled. The rontents should then be pomeel into a lareer healier, and sex-water added four or tire times a day as before. In this way the embryos may be kept alive for a weelk, although they have by this time got into such a large ressel that it is almost impossible to find any of them for microscopic examination.

\section{"THE DEVELOPMENT OF THE EGGS.}

"I will now attempt a brief, popular account of the changes through which the fertilized egge is gratually converted into the complex body of the adult oyster.

"The body of the oyster, like that of all animals, except the very simplest, is made up of organs, such as the heart, digestive organs, gills, and reproductive orwasis; and these organs are, at wome periond in

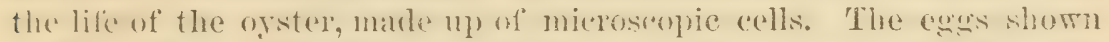

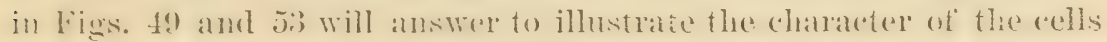

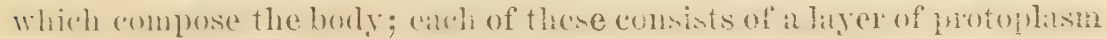
around a central nuclens, which, in the rege, is a larege, cirenlar, trans-

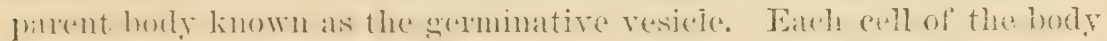
is able to absorl food, to grow and to multiply by division, and thus to contribute to the growth of the organ of which it forms a part. The 
ovarian eges are simnly the cells of an organ of the body, the ovary, and they differ from the ordinary cells only in being much larerer and more distinet from each other; and they have the power, when detached from the body, of growing and dividing np into cells, which shath shape themselves into a new organism like that fiom whose borly the egg came. Most of the stepes in this wonderful process may be watehed under the microscope, and, owing to the ease with which the egg's of the oyster may be obtained, this a very good egg to study.

"Abont fifteen minutes after the egers are fertilized they will bo found to be covered with male cells, as shown in Fig. 51. In abont an hour the egg will be found to have changed its shape and appearance. It is now nearly spherieal, as shown in Fig. 1, aud the germinative vesicle is no longer visible. The male cells may or may not still be visible upon the outer surface. In a short time a little transparent point makes its appearance on the surface of the egg, and increases in size, and soon forms a little projecting transparent knob-the polar globule-rhich is shown in Fig. 3 and in succeeding figures.

"liecent investigations tend to show that while these changes are taking place one of the male cells penetrates the protoplasm of the ergeg and unites with the germiuatire vesicle, which does not disalpear, hut divirles into two parts, one of which is pushed out of the egg and becomes the polar globule, while the other remains behind and beeomes the mucleus of the developing egg, but changes its appearance so that it is no longer eonspicuous. The egg now becomes pear-shaped, with the polar globulo at the broad end of the pear, and this end soon divides into two parts, so that the egge (Fig. (i) is now matle of oue large mass and two slightly smaller ones, with the polar globule between them.

"The later history of the egres shows that at this early stage the egg is not perfectly homogeneons, but that the protoplasm which is to give rise to certain organs of the body has separated from that which is to give rise to others.

"If the egg at the stage shown in Fig. (" were split in the plane of the paper, we should have what is to become one-half of the borly in one one part and the other half in the other. The single spherule at the small end of the penr is to give rise to the cells of the digestive tract of the adult, and to those organs which are to be derived from it, while the spherules at the small end are to form the cells of the outer wall of the body and the oreans which are derived from it, such ats the gills, the lips, and the mantle, amd they are also to give rise to the shell. The upper portion of the egan in this and suceedling figures is to become the rentral surface of the adult oyster, and the surface which is on the right side in Fig. (6 is to become the anterior end of the botly of the adult. 'The figure, therefore, shows the half of the egreg which is to become the left half of the body. The upper portion of the egag soon divides up into smaller and smaller spherules, mitil at the stage shown in Figs. 24,25 , and 26 we have a layer of small cells warped around 
the weater part of the surfae of a single large splerule, and the series of figures shows that the latter in the splerule which is betow in firg. (j. This spherule now dirides mp into a layer of cells, and at the same time the esen, or lat the the embryo, becomes flattened firom above down-

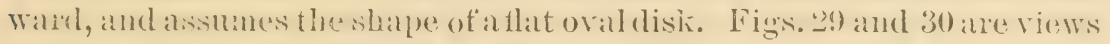
of the mpere and lower surfiue of the embryo at about this time. In a sectional riew, Fig. : 11 , it is seen to be male np of two lavers of cells; an 11 pre later of small transparent cells, ec, which are to form the onter wall of the hosty, and which have been formed by the division of the

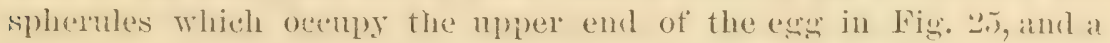
lowere layer of much linger, mores opargue cells, !, which are to become thes walls of the stomach, and whieh hare been formed by the division of the large splerule $a$ of Fig. 25.

"This layer is seen in the section to be pushed in a little towarls the mpler layer, so that the lower surface of the disk-shaped embryo is not tlat, but rey slightly eoncare. This concavity is destined to grow decper motil its edges almost meet, and it is the rudimentary digestive cavity. A very short time after this stage has been reacherl, and usually within fiom two to four lones after the esos were fertilized, the embryo undeleoes a great change of shape, and assumes the form which is shown in threo different views in Fings. 32, 33, 34, and 35.

"A circular tuft of long hairs or cilia has now manle its appearance? at what is thus marked as the anterior end of the boty, ant as soon as these hairs ane formed they bexin to swing backwards amb forwards in such a way as to constitute a swimming organ, which rows the little, animal up fiom the bottem to the surface of the water, where it swims around very actirely by the aid of its eilia. This stage of revelepment, Fig. 32, which is of short duation, is of great inportance in raising the yommer ofsters, for it is the time when lhey eam best be siphoned oft into a sepandate vessed and freed from the danger of being killeal by the decaly of any exses which may fail to derelep). On one surface of the birly at this stagere, the dorial surface, there is a well marlied groove, and when a spremen is found in at proper position for examination, the opening into the digestive tract is found at the bottom of this groove. Fig..3:) is a seretional view of such an embryo. It is secu to cousist of a centrai (avity, the digestive carity, which opens externally on the dorsal smberentibe boly hy a small orifice, the primitive month, amel which is surrombled at all points, exeept at the mouth, hy a wall which is disbinct from theouter wall of the holy. Aromul the primitive mouth these two layers are continuous with each other.

"Yhe way in wheh this carty, with its wall and external openins, lats been formed will be understood by a comparison of Fig. 33 with ris. 2s. The later which is below in Fig. 2s has been pushed upwards in such a way as to couvert it into a long tube, and at the same time the outer layer has grown downwards and inwards around it, and hats thus constricted the opening. The layer of cells which is below in 
Tig. 2- thens becomes converterl into the walls of the digestive trant, and the space which is outsideand helow the embryo in Fis. 23 becomes converted into an inclosed digestive cavity, which opens externally by the primitire mouth.

"This stage of derelopment, in which the embryo consists of two layers, an inder layer sumbumling a carity which opens extermally hy a nonth-lile opening, anel an outer layer, which is eontinnens with the

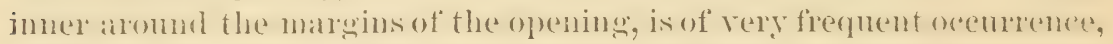
and it has heen fomer, with modifications, in the most wirlely separated gromps of animals, such as the stan-fish, the oyster, and the fires, ant

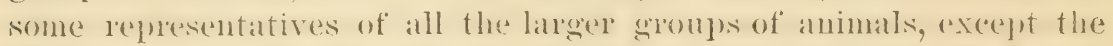
Jrotozoa, alpear to pass during their development throngh a form

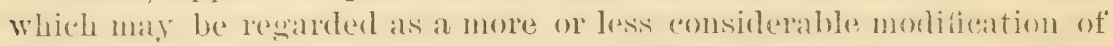
that presented by one oyster embryo. This stage of development is known as the gastrula stage.

"Certain full-grown animals, sureh as the fresh-water hyrha and some sponges, are little more than modified gastrulas. The boly is a simple vase with an opening at one end rommmnicating with a diendestive calvity, the wall of which is formed by a layere of cells which is rontinuoms aloumd the opening with a second lager which forms the onter wall of the bouly. This fact, together with the fact that animals of the mest widely separated groups pass through a gastrula stated of revelopment, has led certain natmalists to a generalization, which is known as the 'aastrulat theory? This theory or hypothesis is that all animals, ('xe'pet the Protozoa, are more or lesis direct descendants of mene enmmon but very remote ancestral form, whose borly consisted of a siatple twowalled vase, with a central digestive cavity opening exterinally at one end of the body.

"Matelel, who is the originator and leading alvoeate of this ligpothe-

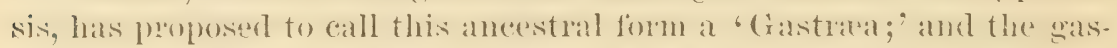
trula stage of derelopment he regards as a trace or indication of this distant ancestry, which is still letained and passed through dluring the early stages of the development of animals which are now rerg widely separated.

"The wastrub theory annot he regarded as one of the established generalizations of science, and the evidence which has so fial heen atecumulatefl by embryologists is mot by any means straightformand or satisfictory. Tle theory is one of the most intresting embryological problems muter discossion, however, and any new intormation which bears upon it is of ralue.

"The faret that the oyster goes through a very weli marked amd very slightly moditied gastrula stage is therefore of great theoretioul interest, and mone so since Sillensliy, a distingushed linssian emblyolegist, has propesed in place of the anstrula theory another theory, which is

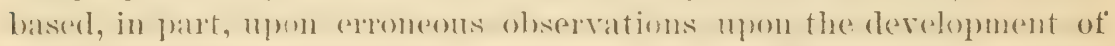
the oyster, which sillensky says does not pass through the gastrula 
stage of derelopment at all, but forms a ligestive cavity in another way.

"The edges of the primitive mouth of the oyster continue to approach each other, and finally meet and unite, thus closing up the oprening, as shown in Fig. 36, and leaving the digestive tratet withont any rommunication with the ontsikle of the hody, and entinely smerenumled ly the outer layer. The embryo shown in Fins. 323 and : 36 are represented with the dorsal surface helow, in erder to fatcilitate comparison with the adult, but in Fig. 35 and most of the fillowing figmes the dorsal surtace is mperemost, for more ready (eomparisom with the alult. The furrow in which the prinitive mouth was placed still persists, and soon a small irrexular plate males its appeanance at eareh end of it. These little plates are the two valres of the shell, and in the oyster they are separated from each other from the first, and malie their appearance iudependently.

"Soon after they make their appearance the embryos cease to

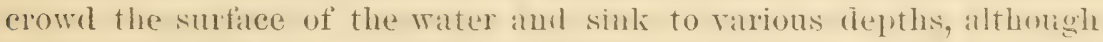
they continue to swim actively in all directions amb may still he fomm oceasionally chese to the surface. The resion of the body whic? camies the cilia now becomes sharply detined, ats a circular projecting paul, the velum, and this is present and is the organ of locomotion at a much latere stage of derelopment. It is shown at the right side of the tigne

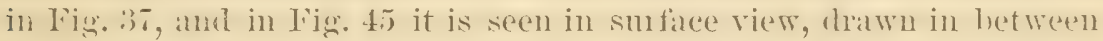
the shells, and with its rilia folled down and at rest, ats they are seen when the little oyster lies upon the bottom.

"The two shells grow rapiuly, and soon become quite regular in ontline, as shown in Figs. 37 and 44, but for some time they are much

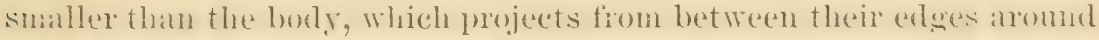
their whole cireumferenere, excent along a short area, the area of the hinge, upon the dorsal surface, where the two valves are in contact.

"The two shells continue to grow at their edges, and soon become lange enough to cover mp and project a little beyond the surfare of the louly as shown in Fig. 41 , and at the same time muscular fibers male

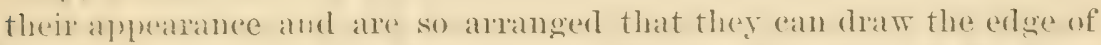
- the bucly and the velum in lestreen the edges of the shell, in the man. ner shown in Fig. 45. In this may that surface of the body which Jines the shell beenenes converted into the two lohes of the mantle, and hetween them a mantle carity is formed, into which the renum ean be drawn when the animal is at rest. While these changes have been

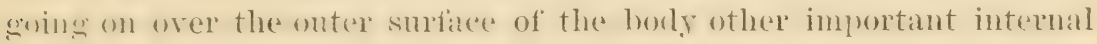
modifieations have taken place. We left the digestive tract at the

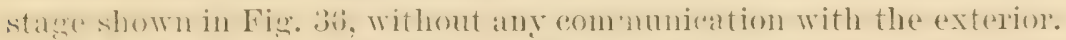

- Fionn the outer wall of the boly becomes pusherl inwards, to form the true mentle, at a point (Fig. 37) which is mpon thes ventral surfaces, amb almost directly opposite the point whore the juimitive month was siluated at an earlier stage. The digs sive carty now becones greatly 
enlarget, and cilia make their aplearance upon its malls, the mouth becomes commected whth the chamber which is thus formed, and which becomes the stomach, and minnte particles of food are drawn in by the cilia, and can now be seen inside the stomach, where the vibration of the cilia lieen them in eonstant motion. UP to this time the animal has developed without growing, and at the stage shown in Fig. sif it is scarcely larger than the mufertilizesl egge, but it now bexins to increase in size. The stages shown in Figs. 44 and 4.5 agree prefty closely with the figures which Eurolean embryologists give of the ogster embryo at the time when it excapes from the mantle chamber of its parent. The American oyster reaches this stage in firm twenty-four homs to six days after the egg is fertitized, tha rate of development being determined mainly by the temperature of the water.

"Soon atter the mantle has become connecter with the stomach this becomes nuited to the borly-wall at another point a little behind the mantle, and a second opening, the anus, is formed. The tract which comnects the anus with the stomach lengthens and forms the intestine, aml, soon after, the sirles of the stomalch become folded ofl to form the two halves of the liver, as shown in Fig. 44.

"Various muscular libers now male their appearance within the body, and the animal assumes the form shown in Figs. 44 and 45.

"All my attempts to get later stages than these fatiled thromgh $m 5$ inability to find any way to change the water without losing the foumg oyster, and I am theretore mable to deseribe the manner in which the swimming embryo becomes converted into the alult, but I hope that this sap will be fillet, (either by future observations of my own or hy those of some other embryologist.

"In myattempt to raise the oyster embryo from the egg, I fomm that continuons warm weather was essential to suceess. As myolservations mpon the developing eagrs occupied all my time, I was not able to make any recorr of the temperature of the water of the ocean, but during Jume there were a number of cold, winly days and nights, and two hailstoms, and on each of the cold datys all the embryo which I had in the house died."

Since 1is9, though several persons have been employed upon the work, and Dr. Broolis has also continued his investigations, no material advance in antificial oyster culture has been made, and beyond the additional knowledere of the reproductive process of the ogster, Brooks's experiments have been without practical result.

Concerning the influences to which the eswes, spermatozoa, and spat are exposed, and the conditions necestury to their survival, Dr. Brovls siys :

"The most eritical dime in the life of the American oyster is moloubterly the time when the exs is discharesed into the "ater to be fertilized, for the (hance that endeh exper which floats ont into the ocean to shift for itself will inmediately meet win a male cell is very slight, aud it is 
essential that the egg should be fertilized very quickly, for the unfertilized exg is destroyed by the sea-water in a rery short time. The next period of great danger is the short time during which the enbryos swarm to the surtace of the water. They are so perfectly defenselesis, and so crowled together close to the surface, that a small fish, swimming along with open month, might casily swallow in a few mouth fuls a number eopual to the human population of Baltimore. They are also exposed to sultden changess of temperature, and as my experiments have shown that a sudden fall in temperature is fatal ro them at this tine, the number which are destroyed by cold rains and winds must be very great indeed.

"As soon as they are sately past this stage, and seatter and swim at various depths, their danger from accidents and enemies is greatly diminisherl, and their chance of reaching maturity increases humcheds, and probably thousands, of times.

"Although the mortality at these enly stages is so expessive, the number of youmg which pass through them safely without helly is vers great, and if there were no other dangers and uncertainties there would be no need of measures for their protection. As they swim to and fro in the water, they are carried to great distances by the tides and currents and reach all parts of the region of water in which the parrent bed is sitnated. In a faromable year a floating plank or bushl, or piese of dritt wood, will be foumd to become covered with suall oyster's which have fastened to it, although it may not be within miles of any matural oyster bank. The fanct that the young may be collecterl in this way in any part of the Chesapeale Bay shows that the young oysters must settle down mon the bottom in nearly all parts of the bay, and we shonh expect the arlults to have an equally general distribution. 'This is far from the ease, and nothing eould be farther from the truth than the idlea that the bottom of the waters of the oyster reswions is milom $y$ corered with oysters, and that it is only necessary to throw a dredge overboard and drag it along the botton for a short distance in order to bring it up full. Tothing conld be a greater mistalie, for both in this country and in Europe the oyster's are restricted to particular spots, 'beels' or 'banks,' which are as well defined amel almost as sharply limited as the tracts of wood land in a farming country. These beds are so well marked that they ean be laid down on a chant or staked ont with buoys; and eren in the best oyster regions they ocenuy such an ineonsiclerable part of the lottom that any one ignorant of their position would have very little chance of finding oysters by promiscuous thed ma. Although the young are distributed every year by the tides and currents fo all parts of the bottom, the dredge very seldom brings up even a single oyster outside the limits of the beds.

"The restriction of the oysters to certain points does not appear to depend npon the supply of food, or upon the character of the water, but almost entirely upon the natme of the bottom. The full-grown oyster in able to live and flourish in soft mud, as long as it is not buried 
too deenty for the open elge of the shell to reach above the mud and draw a constant supply of water and food onto the gills. The plareing of adult oyster's mpon such hottoms at convenicent points to 'fatten' for the marliet is a well-known practice. The ogster embryo would be ingulferl and smothered at once if it should settle down on surh a bottom, and in ordere to have the least chance of surviral and long life the young oyster must find some solid substance to fasten itself to, in order to freserve it from sinking in the soft mud or from being covered hy shifting sand or glatrel. As soon as the oung oyster finds such a solid houly, rough and clenn, it fastens one valve of its shell to it by serenting a cement of shelly matter around the growing edge.

"The living and deat shells of the abult oysters fumish the hest surfaces for the attachment of the young, and for this reason the points where oyster berls are already established are those where the young have the most farorable surromelings and the lost chance for lilie and the berls thus tend to remain permanent and of substantially the same size and shape.

"The great mortality of the yomeng after they have fastened themselves to the shells of the arlults, is due in part to want of room. in part to the attacks of enemies, in part, to accidents, such as the shiffing of the bottom, and in part, no doubt, to lack of foul. While the supply of organic matter which is amied to them hy the water is very coreat, it is not unlimited, and the amount which each ojster can obtain at any one time is guite small, and if the oysters covered the bottom in suficient abundance, some of them might fail to obtain a suflicient supply. I do not believe, howerer, that this erer occurs, for loug before the ogsters are suniciently abmulant to exhaust the supply of oramic matere, their mumbers are limited by other conditions. The growth of an animal dess not depend upon the supply of food in eneneral, but mon the sumply of the least alumdant of the neessary ingredients of the food. It is well known that a field that is rery fertile will fail to promluee a satisfactory erop of a plant mhich meeds some particular foodinglexlient whirh the soil eontains in too small gyantity. Although fool in genceal is very abundant, the gerowth of this particular crop deprends upon the amomnt of this ingredient, and while the seed which has heen planterl vields an abundant crop of yomng plants, only a few are able to wrow 11 , and these (an wow no firster than they ean extract this manticular ingredient from the soil.

"In addition to organic food, the oyster needs a supply of carbonate of lime to make its shell, and this is supplied to it, in solution, in seawater. If the shell is thin, or if it is formed very slowly, the danger from enemies and aceiclents is gleatly increased ; and those oysters which are able to eomstruct their shells with the greatest rapidity ale the ones which survive and grow mp. The amount of dissolved carbonate of lime which the ocean contains is mulimited, l. ut the amonnt which can reach each oysteris is not very geat ; and if all the oysters which attach 
themselves mere to survive there can be no donht that they wonkt exhaust the arailable supply of lime before they failed to obtain enough organic food.

"It is well known that shell-fish of all kinds thrire hest when the supply of lime is greatest. The fresh-mater mussels which live in streams and pouds where the supply of line is seanty, grow slowly, and their shells ane so thin that they are rery subject to acciblents, and their numbers are linited; but in limestone regions the shells are large and heary, and the bottoms of the streams are almost pared with mussels, anci it is well known to conchologists that coral rectis and islanch are the most favorable regions for the abundant growth of all hinds of shelled molluses."

The investigations of the Enited States Coast and Gerbletic Surver, in the neighborhood of Crisfedd, Maryland, which were wineintent with those of Dr. Brookis, led to the eonchusion that there is little or no regularity in the recurrenee of successful "spatting" seatsons, and that all irregularities are due, pobably, to variations fiom the normal temperature and density of the water; the higher the tempreatme during the spring months the earlier will be the atrent of the spawuing seatson, and an increased temperature will also hasten the development of the spat, and of the gomeng oyster's after they have heeome attaredeet. Sudten and extensive changes of density will likewise allect the adrent, duration, and sneeess of the spawning, thongh to a less extent.

Subserpent to the attachment of the animal, changes of the conditions surromuling it are not of so mush importanen, thomgh matmally such changes will more severely afferet the delicate organism of the young oyster than that of the older and more hardened adult.

It is luring the first six months of its existence that the ogster is exposed to the greatest danger from its numerons enenies. The thin, delicate shells, from one-sixternth of an inch to one inch in cliamerer, are readily bored by the drills, whellis, and other gastropuls, or tom off by the crabs, and the immense number of all leares no room to donlbt their destructive effects. As an instance, the insurection of the spat collectors placed in the Big Amemessex liver by the United States Coast Survey, shows that during the early monthes of their existence about 50 per cent. of the yomg oysters were destroyed.* Xatmrally, as the animal progresses, it becomes more hamly amel better ablo to resist the attacks of enemies and changes of enviromment, and on unworlied beds, where the oyster's are practically in al matmal state, the decrease in passing from young growth to mature oysters is about 30 jere cent., or ahout one-third of at giren number perish in passing from the first to the fourth year of their existence.

The only essential for securing the attachnent of the spat is that the olject exposed shomld be rhan. The speeinens illustrating attarhment show how many and ranious these olyeets are; amb the formation

* Photographs of this collector are exhibited. 
and pxtension of an oyster-bed are due largely to this ability of the renug fry to hold on to anything and ererything. The beginning of a hed is probably in most cases accirlental. There is an exposure of some ohject suitable for attachment, to which the drifting embrys clinge and succeeding seasons ald to the colony and slowly increase both its popnlation and area; the natural linits are defined by the amount of fool and constituents of shell avalable, the amount of room for derelop)ment, and the character of surromding, contiguous bottoms. Oysters cannot live on bottoms not sufticiently consistent to surpurert them; they are muprovided with siphous, or means of locomotion, and if sunk in murl or samr will perish. Neither can they live for long periods ont of water muless especially educated for that contingency.

Natural oyster-beds on the Ameriean coast are of two classes; worked and unworked beds, each presenting marked features.

The following extracts from the reports of MIs. Winslow to the Superintendent of the United States Coast Survery, describing areas in Chesapeake liay, imblicate the salient features of each class. The berls esntrasted are located in Chesapeake Bay and 'Taugier Somd, an adjacent estuary of the bay.

"Crenerally speaking, here as in the Somnds, the original heds were former on the siale of the shoals, and wherever there was a sudilen change of bottom.

"Whenever the solid beds or 'Roels' were encountered, they were fomd to be long and narrow ridges, extending generally in a northerly and southerly direetion, exeept when near Kedge's Strait, where they ran more to the rastward and westwarl; and we could, in standing across the bexis, but rarely obtain more than one or two hauls of the dredge before we were off the 'Rock.' The major axis appears here, as clsewhere, to lie in the direction of the current, and probably all natural extension and growth of any bed are in that direction, the spat heing carried batelewel and forward by the ebo and flow of the tides. The large number of beds near and oft Kedge's Strait is probably due to the large number of spat hrought out from the Sounds throngh the strait.

"The hottom is frenerally of hard sand covered with sponge aud grass. Tear Kerlge's Strait some mul sloughs were fombl, and in some cases the substratum of the berls was of elay; but in most of them the stratum of oysters aud shells was too thick and hard to be peuetrated.

"The beds outside the Somnls have been comparatively free from dredging, and thus present marked differences from those inside.

"They are comparatively longer and narrower, and much more sharply defined. Very few scattered oysters are fomm near them, and the beds are much more solid, mbroken, and much lander, requiring heavier drerlges than those used in the Sounds. The most remarliable difference is, however, in the shape and growth of the oysters.

"On the modredged heds they are long and narrow, with the lower shells rery de(p) and bills rery thiu and sharp. In no case did we find 
any single oysters of any class, lout all grew in clusters of from three and fon to twelve and fiftern. The shells were clean and white, and free from mud and sand. Generally there was fond a tuft of red or white sponge attached to the clnsters, and the mature first and simomel cliais oysters were corered and the interstices between them filled with those of the third and fourth classes; numbers of harnacles were also fonnd, and some crepidula, but tubicolu were present only in small mumbers.

"The oysters foumd upon beds that have been much worlied differ materially, being single and broaler in comparison to their leng:h, roumd and with blunt bills. They are usually dark in color, and have at consiflerable amount of mud and sambl on the shells. The sponges do not appear to be as abundant, and the amount of dredging on any bed mat always be linown by the appearance of the oysters brought up. L Lon an overdredged and almost exhansted bed the oysters will be large and single, b! mut-billed, with dirty shells, and with an almost entire absence of sponges, barnacles, and crepridula; but the shells will he covered with tubicola and bored in many places by the boring pholad.".**

Aside from the eflect of the dredge the growth of the orsters on a bed is influenced by many other ciremintanes. Finst, the prosition and charateter of the object to which the spat fixes itself have a large intluence in shaping the form of the shell.

The growth of the "bills" is always toward the surface of the water, and by examining the series of specimens "of peculiar spowth, due to attachment of spat," many instances of the curious effect of this aftort of the animal will be noticed. During the early stages the shell girows directly ont from the beaks; later, the tendeney of the lower valve to assume a convex form becomes more marked, and, shouk the animal be so attached as to be in a horizontal position, this convexity of the lower valve beromes rery prominent. If the attachment is such that the lips of the values are below the beaks, the shell will begin to take a lateral twist, which will sometimes change the direction of shell-growt has much as 90 dlegrees. Again, should the spat attach in large numbers to any olject and become much crowled, having no room for growth or derelopment, exeept vertically, then each individnal shell will become long, thin. narrow, and with very little convexity of the lower valve. Of such description are the oysters growing on natural, undeveloped banks, where they are found in enormons clusters, of from ten to fifty individ. nals. Such oysters, more common on the Southern coast than the Northern, are called "cat-tongues" and "linife-blades" by the oystermen. "The "raceoon" ofster is also of somewhat similar growth and eharateter.

After having developed to some extent in one loeality or position, if the urster be removed to some other point, where the conditions influencing its growth are changed, corresponding ehauges in the character and growth of the shell may be experted. These changes are it-

\footnotetext{
* Photographs of specimens are exhibited illustrating these differences.
} 
Instrated by the series showing "peculiarities of growth due to alburmal influences or change of position subsernent to time of attachment." As shom by some of the specimens, owing to change of position, and the eflort of the animal to lieep the tips of the valves uppermost, the shell has two and three distinet changes in direction of growth, and these changes are sometimes lateral. as thom the shell had always fallen on one siste or the other; sonetimes dorsal and ventral, as thomgh it hatd allatys fallen on one wedge or the other; and sometimes the irregular growth is a combination of both. This peeuliarity is more fregnent in orsters from enltirater than in those from natural beds; but it is more marked when it does occur with the natural oysters than with the cultivated ones. As the cultivated beds are more continuously and systematically ralied, probably each oyster is tumed over once or twice a year, and seldom has an opportunity for any peculiarity of growth to berome deciderl. The natural oyster, however, is rarely handled much hefore being conveyed to market, and eonserquently any unusual growth forced upon it is apt to be very remarkable.

The rharacter of the bottom has not only a very deciked influence upon the growth of the beds, but also affects the growth of each indivilual orster. The shells from impure, mudry waters, are msually dull colored and solt or friable, and when the bottom is very soft, the long flat growth is the only form that has any chance of survival. Tyres of this form, the "pinched" oyster of the fishermen, are exhilvited. A large amount of soft mul, either' in the water or on the hottom, likewise aftecets the interior shell-layers. Particles of the muddy soil get between the valves and under the mantle, amb the animal builds a thin layer of shell over them, amsing thus the dark blue and black spots about the edges of the sheds and were the interior surface, so noticeable in specimens from mudily localities. These peculiarities are shown in the series illustrating the effects of soft bottoms. Shells from hard bottoms and pure water's are much "leaner and harder in character" the shell layers are thinner and less friable, and the boreal form more prominent and frequent.

The rate of growth of the Ameriean orster varies with the locality. Generally spealing, it is slower in Long Island Somnd than in the Ches. peake, the northern oysters not being considered fit for market until three or more years olsl, while in Maryland and Virginia water's they attam a marketalle size in a year and a hall or two years. They are, lowerer, at that age, quite small and are used for steaming or inferior grarles of "plateledl" stock. The size of" the animal at diflerent ages also varies with the locality, as does the quality and flaror; but these last two rhalacteristies ane hy no means coustant, even in the same locality.

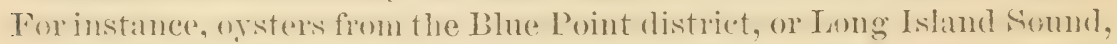
may be the best in the market during one winter and the worst during the next. Only aletual inspection, each season, can decide the companative merits of the crop from the various localities. 
The beds along the entire coast are subject to nearls the same vicissitudes of climate and other natural courlitions, influencing the life of the oysters, and as these viscissitures are not peculiar to the American beds, nor to the mollusean life aloue, they do not require special allusion. The number and character of the enemies and the extent of their ravages depends upon the locality. The mamex in which the worti of such as belong to the mollusea is aceomplisherl, has ahearly been rescribed; but, in addition to the destructive eflects of the valuiom gursteropods and bivalves, the oysters, in common with several other shellfish, hare to contend with other foes, bexouging to other sub kingelonis. Chict anomg these are the star-fishes, amel the most promineut of that destructive timuily is the Asterias forberii, or "green" stan-tish. They"

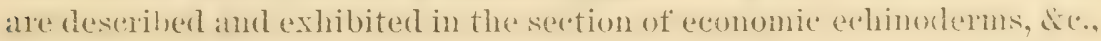
and specimens of oysters and star-tish, illustrating the method of attark of the latter, are aiso exhibited in the mollusean collection. The mannex in which the oyster is eaten is described by l'rofessor Terrill, as follows:

"Alter bending their fire flexible rays around the shell so as to patrily inclose it, they protrule the lobes and folds of their enemons sacenlar

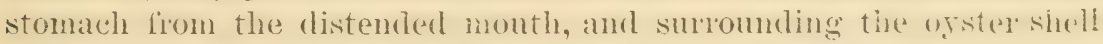
more or lesis completely with the ererted stomach they proceded to diwest the contents at leisure, and when the meal is finished they quicely withdraw the stomach and stow it away in its proper place."

The star fishes are very destructire in Lomg Island Somm, but furthrr to the sonthward, and in Chesapeake Bay, do less damage.

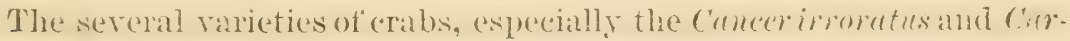
cinus menos, flestroy many oysters; usnally the young are selected, as they are mere vulnerable than the mature animals; the danalge loy crabis, however, is not nearly so great as that done hy the stan fish, ambl thongh the Chesapealie region sufters nore from this enemy than the

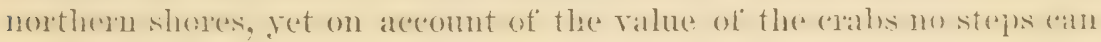
or will be taken to lessen their numbers. Two species of fishes, the

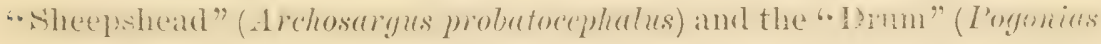

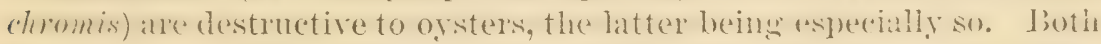
fishes are povided with teeth with which they erush the yomong anduals. and histh nsually swallow them, shells and all. The Drum is the rlicet reprerlator, but roes not often tronlile the berls nerth of New Tork. On the New Jersey eoast, howerer, it abounds, and moving in sehools. will fieryuntly devastate thousands of dollats' worth of property.

The minor enemies may be despibed as complising all torms of ani-

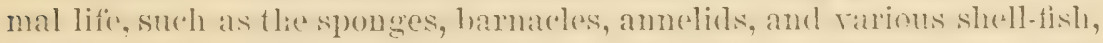
that hy their presence on a bed deprive the ogsters of foud or room find development, or, like the musisels, attract other more directly injurious animals.

The boring-sponge (C7iond sutphurea), and the red branchings sponge (Microciona proliferea) are the principhal representatives of the sponyia. $22 \mathrm{~S} \Lambda-3$ 
The former does direct damage occasionally, by its attack on the shells, but usually it rather prepares the way for other enemies than aceomplishes anything itselt. The latter.is not directly hamenful, but growing sometimes in great masses, it not only prevents the food supply of the oyster from reatily reaching the animal, but interferes with the at tachment of the young hood. Hence cultivated beds should be liept clear of this as well as the boriug-sponge.

\section{OYSTER INDUSTRY.}

\section{'TiE FisHery.}

The fishery is regulated by the laws of the rarious States, the Federal Gorermment cxercising no control, and consequently the conditions moler which the pursuit is followed are many and rarions. At the present time the laws relating to the oyster fishery may be said to be batserl upon one of two general principles. The first, the basis for the regulations of most of the States, consider's the oyster beds to be inalienalble, common property. Laws based upon this principle are gencrally of a protective vature, and are in rality regulations of the State, made by it in its caparity of guardian of the common property. The second princinge assmes the right of the State to dispose of the arrat at the bottom of its rivers, harlor's, and estuaries, and havine disposed of it, to consiner the lessee or owner, as alone responsible for the suceuss (I) failure of his enterprises, and the State in no way called mpon to aflord him other assistance than protection in legitimate lighlits. In weneral terms, under the first principle, the beds are helel in rommon; moler the second, in severalty. But one State permits the preemption of an unlimited tract of hottom, and the holding of it in fee : the state of Connecticut. Thhorle Island leases her ground for ab term of gears, at S10 per acre; but the person holding an area has no legal power of disposing of it beyond the limits of the lease. Massachnsetts, New Iork, New Jersey, Maryland, and Virginia, all permit presemption of small tracts by individnals for indefinite feriods, and on the coast of Long Island the various town along the shore lease tracts of considerable extent to private cultivators.

Various restrictions are also placed upon the time and mammer of conducting the fisheries. Some of the States, noticeably Vircinia, prohibit entirely the use of the dredge or scrape; others, noticeably irew Jersey, prohibit such use in some localities and permit it in others. All the States, with one exception, prohibit the use of steam ressels or machinery, or tishing by other than their own inhabitants. Comnecticut again forms the cireption, and quite a large flect of steam dreaging ressels are employed on her beds.

The laws of the varions States have several common foatures. All general fishing is suspencled during the summer montlis. No night fishing is permitted. No steaners are allowed to be used. No pro- 
prietary rights to particular areas are giren bepome the right to "plant" a limited number of oysters on hottoms adjoining land owned bỵ the planter and peace oflicers and local anthorities are charoced with execution of laws relating to the fishery. In a few States or localities, licenses are repuired to be obtained for each fishing vessel ; and in one State, Maryland, a regular police force and heet of ressels is maintained to support the law. These regulations are easily eraded, except those relating to the steamers and pre-emption of ground. Saturally, no one will put down oysters without being able to protect them; and steamers are ton readily detected to make their illewal employment possible. In Connecticut and Rhordo Island, the beds being virtually mivate property, there is no restriction of the fishery, except that it shatl not be condueted at night.

The character of the vessel or boat nserl, depeuds in a measme nuon the means of the fisherman and the constancy of his employment. When the beds are small aud worked only at intervals, or where the oysterman is poor, a small boat of any description is med. Dories have the preference on the New England coast, and canoes in the Chesalealie Baly. Shatpies are also msed in Long Island Somnd. If the beds are cxtensise, furnishing eomstant employment, or the oysteman is rell to do, the size and appointments of the fishing eraft are much immored. The characeter of the oyster gromul, its location, and the laws governing the fishing, also influence the true of ressel or boat userl. Shoal-water berls, in sher tered localities, where dredging is not permitted, are nsually tished from small, open hoats: as, for instance, the heds of Phode Island, south shore of Iang Island, sea-coast of Xew efersey, and Tirginia waters. On the other hand, beds lying in deep water, in exposed positions, and where dredging is allowerl, are rorked by larwer eratt of 10 to 40 tons, or steamers; as is the case in Lomg Island Somnd, Delaware and Chesaparlie Bars. One of the foregoing ennditions also decirles the imple. ment to be used; when permitted, it is the Aredge-either the promous one employed by the steamers, the smaller toothed ralie-dredge, or smooth-serape. When dredging is prohihnted, the tongs, or nimpers, with two handles, sometimes 30 feet long, are used.

The dredges ate usually worked by an ap) paratus termed a "winder." Many forms of "winders" (a winch especially adapted for this purpose) are (mployed, but the one exhibited is the best and has the latest inprorements. It is sodesigned that if, while recling in, the dredere should "hann," that is, heeome immovably fixed loy some obstruction on the bottom, the drmm is at once antomatieally thrown out of gearing, and the dreline-ropeallowed to rum out; the sudden and rapid reverse revolution of the hrakes, which has caused many serions acciolents and considerable loss of life, is thereloy prevented. Small craft use a more simple and less expensiro description of winch, and frequently hanl in by hand, while the steam dredgers hare powerful makhinery arlapted for this special purpose. The number of men employed rarics ir ith the size of the craft; 
two, three, and four men are suffeient on board the smaller dredgers, while the larger carry tro and twelve. The average sized "pungy" in the Chesapeale has a crew of seven or eight, aud the majority of the "tongines" canoes employ one man and a boy.

In the Chesapukt each han of the dredge is "culled", that is, the oysters ale separated from the shells and refuse, as soon as the dredge is on derek, and everything except the oysters is immoliately thrown orerboard. In Long Island Somml, howerer, and on all private beds, the culling aloes not talie place until the end of the day, when all shells, or of her matters suitable for "strols" or "cultch," are put on the shell-heaps on shore for subseguent ust, and no refuse matter is thrown back on the beals. In each lowality the poliey is unchanged when the fishing is conducterl by means of the tomss, amb the dillerence illustrates the degree of care exercised on private and public beds.

'The fishermen, as a rule, are of the lower class and generally very ienorant. The masters of the lareger vessels employed in the Delatwate and chesapeake are more intelligent, and the oysterman of the Northe ern and Fastern Sitates is superior in cirenustances and education to those of the Sonthem Stales. The "tongers" in both sections are better to do in the world, generally owning their hoats or canoes and working for theix own probit, than the men engaged on the lareser dredging ressels who are not above the ordinary day-laborer in condition.

The packing trarle is comnon to the whole seaboarl, but the steaning and canning industries are confined mainly to localities sonth of the Delaware. A general desceription of each will gire a sufficiently exact idea of the methods emplosed, there being but little local variation.

While a great maty oysters are transported in the shell to marlects distant from the seaboard, the largest part of the inland consumption is of "opened" of "shrelical" oysters, and nearly every oyster dealer along the coast emplogs a larerer or smaller number of persons to open the orsters and pack and ship the meats. Some of these establishments are small, having as few as half a dozen people engaged ; others are lange hublings or sheds, and employ hmolreds of "shuclises." At some points-for instance, Fair Ilaven, Comm., and Crisfiels, Mn.-the shores of the rivers are lined with long whitewashed sheds extending hateli from the wharves; and it is withm these sheds that the wonucking" takes place.

The usual arrangement is as follows: The building is divided off in long alleys; on cateh side of each alley are numerous stalls, eacelo fitted with a "shucking trough," or box-like receptatele for the oysters in the shell. In the frough are two buckets, one to contan the oysters of ordimary size, the other the larege "extras;" a block of wood with a flat giece of inon set in it, with its edgerem), on which to break the bills of the oyster; a hammer for the same purpose, ancl an oyster linife. A work-

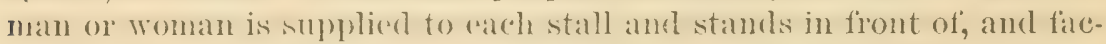
ing it, the feot and lexs being protered and linet elear of the increas- 
ing pile of shells by a woolen shield. Mren and women, white and black, are employed, but in well-arranged houses the sexes are assigned different alleys, and ia many the same distinetion is observed with regand to the races. The buildings are ronghly put togetler and are necessarily dirty, slopyey, and meomfortable, usually being but imperfectly heated by laroe stores. The shucking tronghs are supplied with oysters fiom the lots receired during the previous day and night, each shucker informing the foreman when his trough is emptied. The same men and barrows that carry the oysters from the resselis or piles to the shuckers, remove the shells that collect on the floor. In shueking, the workman takes an oyster from the heap in the trongh, and holding it in the palm of his left hand, the bills projecting and towatrds him, and with the linife and hammer in the right hand, he lays the lips on the bereled extge of the iron projecting firom the block of wood, and with at blow of the hammer breaks ofl the bills; the knife is then entered, the valves separated, and the oyster remored and thrown into one of the buckets. In lihode Island and some parts of New England the hammere and block are not used, but the oyster is "stabbed"; that is, in. stead of brealing the lips of the valves, the linife is entered at the sule and the abductor muscle cut. When his bucket is funl the shucker carries it to the end of the alley and pours its contents into al trough labding through a hole in the partition dividing the shuckers from the receivers. The oyster's are thus run into a sheet-iron or zine receptacle "alled the "skimmer," which is pertorated with holes to allow the liquor" to sun off, and are there cleaned of shell fragments and measured. Each shucher has a number, which he gives as he empties his bucket; at the same time he receives a talls-check and his gallon is seored up, to his credit on a huge blarkboard. At the end of the diay the amount of each score is entered in a book, and the employés are paid at the end of the week. Shuckers make from 75 cents to \$1 per day in the Maryland houses, and about jo cents nore in the New England establislments. The men usually make more than the women.

From the "skimmer" the oysters are put into enormous tubs, and from thence are taken, a few gallons at a time, to the "cullender," a sheet irom or zinc basin, perforated with small holes, where they are thoronghly washed. From the cullemder they are transferred either to small cans, holdinge a quart of oysters, or to barrels, liegs, or tuls; when proled in tuhs, leass, or barrels, they go in bulk, with a large piece of icen; when palcked in the tin cans, the cans ane arranged in two rows inside of a long box, a ricant space being left in the center, between the rows, in which is plated a large block of ice. The cans are carefully soldered nu before parting, and together with the iee are laid in satwdust. Oysters packed in this way can, in cool weatler, be kept a week (ir more, and sent arross the eontinent, or to the remote western towns.

The steamiug prncess is that by which the "core" oysters are prepared. The term "cove" is applied to ogsters put up in cans, hermet- 
ically sealcel, and intended to be preserved an indetinite time. The trade in "coves" is confined priuciparly to the Chesalpealie region, and the process of preparing them is as follows: The oysters, usually the smaller sizes, are taken fiom the ressels and places in cars of iron framework, 6 or 8 feet long. These carss run on a light iron track, which is laid from the wharf throngh the "steam-chest" or "steam-box" to the shucking shed. As soon as a car is filled with oysters (in the shell) it is run into the steam-ehest, a rectangular oak box, 15 to 20 feet long, lined with sheet iron and fitted with appliances for tmoning in stean; the doors, which work vertically and shut elosely, are then let down, the steam admitted, aud the orsters left for ten or tifteen minutes. The, chest is then opened and the cars run into the shncking sherl, their places in the ehest being immediately ocenpied by other cars. In the shed the cars are surrombled by the shnckers, each provided with a linife and a can arranged so as to hook to uprer bar of the iron frame. work of the car'. The steaming having caused the oyster shells to open more or less widely, there is no difliculty in getting out the meats, and the ears are very rapidly emptied. As soon as each shuclier fills his can he turns in the contents and receives his tally-check. The ofsters, as they are receiverl, are washed in iced water and then transferred to the "fillers" table, where they lie in great heaps. The "dillers," nstally" girls, are employed in filling and weighing the romol tin cans, which are such familiar objects in every grocery. The cans, having been fillecl, are removed to another part of the rom and packed in a eylindrical, iron crate or basket, which will hold six dozen or more of them. When the crate is full it is lifted by means of a derick and lowered into a large cylindrical kettle, called the "process liettle" or "tub." The lid of the "process liettle" is then elosed and screwed down, and the oysters again steamed. After this serond steaming they are placed, crate and all, in the "cooling tub," a rectangular tul, containing cold water, and when sufficiently cool to be handled, the cans are take'n to the "calperers," or soldering table, and there "capped ; that is, are hermetically closed. From the "capper's" they are transported to another department, labeled and packed in boxes for shipment. The whole steaming process will not oecupy an hour from the time the oysters leare the ressel until they are ready for shipment.

The only other branch of the indnstry not yet alluded to, is "planting," and as this varies with the different States, it is considered in detail. For the eapital invested, number of bushels produced, and persons employed, see the "statistical" table at the end of the pages deroted to the oyster.

Haine.-This State is noterorthy on account of her past rather than her present resources. At Damariseotra, and the Sheepseot River, great shell-heaps exist, emposed mainly of oyster shells of wigantice size; but there is, at the present day, hut one small natural hed, situated some few miles west of Jamariseotta. In I'ortland Jarbor, or Casco bar, a few hundred bushels of oyster's, that are brought from the Chesalueale, 
or Is)ng Island Sound, are laid down on the flats in the summer to fatten. They will not live throngh the winter, and usually are not allowerl an opportunity to attempt the experiment.

Su Humplhire. There was, until lately, a latge natmal hed in this State, in the I'iseatagna River, but orer-tishing has caused its practical extinetion. Oysters aresupplied the market by importation from other localities, either directly, in kegs or tubs, or in the shell by the eargon. In the latter ease, the animals are "laid down" for the summer months in the Piscataqua.

Masiachusetts.-North of Cape Cor, no natural oyster-heds of any importance ocenr; though at the months of the varions rivers and at Wellticet, on Cilpe Corl, they have existed in the past. The extinction is supposed to be due to clinatic changes and orel-fishing. I few opsters from other lowaties are "bedded" or "Iard down" in the spring and smmer months, but most of the marlet supply is deriver from direct importations, either in the shell or openel. Quite an important trade in the latter class is earried on between Boston and Torfolle, Val., amounting in 1550 to 250,000 gallous. South of C'ape Cod, in Buzzard's Bay, are many natural beds, and quite a flourishing husiness is carried om in thein vicinity; but this is owing in a large degree to the system of cultivation of private beds. The general practice is to take the oysters from the natural banks and deposit them on the private ones, to grow and fatten; shells are also deposited to catch the drifting spat, but the sinecess of the latter methoh has not bexn so ereat as elsewhere. Oysters are also imported from other localities for "ledding" or "lay ing down," but mulesis from arljacent Statex, they do not do well or outlive the winter. The laws resulating oyster planting and larming, permit. town and city authorities to grant licenses to work tracts of buttom for twenty years. The extent of tracts is not limited, except that they shall not inclucle any natural bed. Night fishing is not permitterl, and infringement of the rights of the person holding the license is punisher by a tine of not more than $\$ 100$ and impisonment of from thirty days to six months.

lihorle Istand. - The natural beds of this State are neither extensive. nor exeredingly prolific. They lie principally in the Sechonti liver, a blanch of the P'rovidenes River, and in Cole's and Kickamuit Rivers. The "latural wromth" ale rarely used in the marlests, but are taken in great mumbers when young and placed on the private artifieial beds, locaterl, for the most part, in the Providenes River. The Serelisk fur. nishes betreen five and ten thousand bushels of "seed" annually, and two years" gavoith on an antificial bed makes them marketable. A large number of oysters are also imported from Long Island Somd and the south shore of Long Lsland for the purpose of "seeding" ber?s. This process is simply to purchase yomg oysters, about a yoar old, and spmead the cargo as erenly as possible orer the area to be "seeded." This is freduenty supplemented hy spreading shells of oysters of scallops over and about the area diring the early summer mouths, and with them a 
number of "inothess," or large oysters about to spatwn. Tisually 100 bushels of "mothers" to 4,000 bushels of shells are put down. Cireat sucersis las fiergnently followed the adoption of this system; but mauy failures have also occurred, the causes for which are obscure.

The "herding" or fattening of "Vireninias," or southern oysters, is the most profitable part of the businesis in this state, and about 500,000$)$ bushelis an laid down ammally. They do not live throngh the wintere, nor can they stand the royage north dming the summex; conseguently, the laving down is done in the spring, and the oysters ant sold during the antumn.

The laws governing the private oyster-herls permit the leasing, hy any inhabitant of the State, ground helow tidewater mark, and outsive of harbor lines, for five to ten years, at an anmul rent of है 10 prer acre; prohibit fishing at night, and punish infringements of the rights of leseses by fine and imprisonnent. Abont 1,000 acres are at present under cultivation under the above regulations.

Connecticut.-Lilie lihorle Island this state has no natmal ogster-berls that ale of inportant size or produetireness, when compared with her artificial, private beds. Such as exist ane larerer and more numerous in

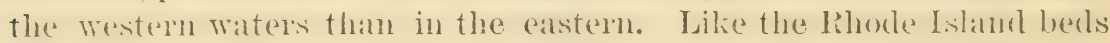
they are fisherl priscipally for "seed" for the private areas. The system of cultivation in this State is similar, in all essential points, to that describerl in lihode. Island, but is much more extensively arbopterl, the area under cultivation being enormous. More attention is given to "planting" shells and other suitable culteh than in Rhode Lshand, and the farms differ from those of the other State in lying, generally, in much deeper water. The Rhode Island planters seldom work in water of more than three fithoms dejeth, while the connectient men are throwing shells and oysters over in fire and six, and even deeper water. Another feature is the seleretion hy the latter chass of hard hottoms in juclerence to any other. The nse of steamers and the constant raking and reansing of the beds is another distinguishing chandeteristic of Comnectirut oyster errowers. Lallege importations are made from Vir-

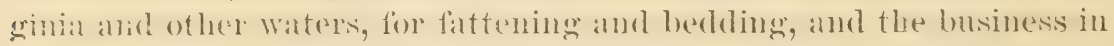
this particular is entirely similar in methods to that of lihokle Island, and absut the same quantity of oysters are imported. The native oys ter business, howerer, greatly exceeds the oftere, both in value and rol-

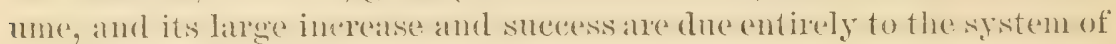
cultivation adopted and the laws protecting it. In this region, in

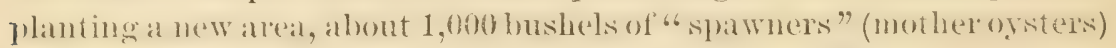
are put down, to 7,000 or $8,0(4)$ bushels of shells. The spawners are

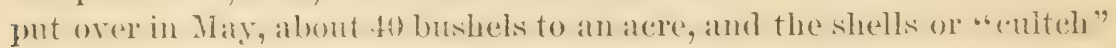
in July ; fomms sedersters are sometimes alderl. The expense is not

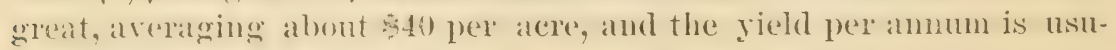
ally donble that amount.

The law governing oyster planting and farming permit the purbanse, at $\$ 1$ fer acre, of unlimited areas, by residents of the State, provided no 
matural oyster bed is included. The gromud is taxed as is also the crop. At the present time some 20,000 acres have been disposed of:

Tere lork.-Throughout the waters of this State are numbers of nat. umal ogster-beds, but all are in a more or less impared condition and would by no means supply the demand if their eflorts were not supplemented by rultivation and importation from Yiew Jersey and I) aliware and ('hesapeale liags. These importations are made directly, the oysters coming in the shell, or opened, or are brought in "ardeges amb "bedded" or "laid down" to fatten. A very prevalent method in this region and to the southwarl, is to put oysters in fresh or slightly brackish water before selling them. They are thus swollen and appear fitter and plumper. The methods of cultivation are siniha to those of Connerticent and lihorie Island, thement on the sonth shore of Lones Istand not much dependence is plased upon foreign stosk, while in the East liver there is considerable importation from other localities of "seed" and "sparthe's." The cultivation of private beds is lewnlaterl to a great extent by the anthorities of the towns. The State law permits the breemption of tracts for an indefinite feriorl, the lensth depending mpon the continuity of the coltivaton, and probiluts the use of steam resisels. Along the nouth shore of Long Island these trabets are

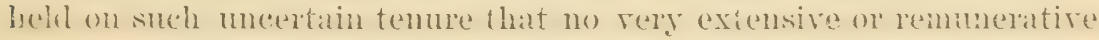
business ean be done; but on the south shore of the island a letter system is in operation, and especially in Great South bay, (Blue L'oint district) the oyster fams flomrish. The practice the pe is to lease the ground at a rent of $\$ 1$ per anum for each acre. Taxes are also laid on the fleating property and stock on the beds. The town of bionokharen, in whose jurisfliction these beds lie, reediver an income of abont

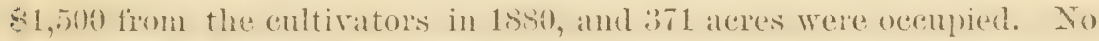
diefiging is allowed, and natural beds are common to all residents of the town. These beds are, however, being fast depleted of their stock, and the supply is gradually fitiling.

The laws of the towns to the westrard, on the south shore, wenerally

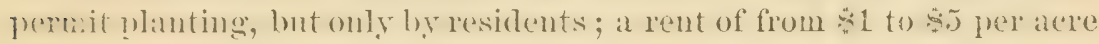
is required, and no dredging permitted.

New Jersey. - This State has many extensive, natural oyster beds, both along the seaboand and in lockwate and Newark Bays: but the

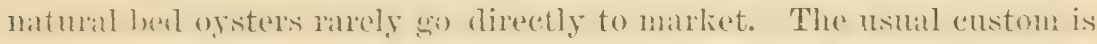
fo trabsplant them for a season to water and bottom differing from that of their original locality. The Shewshury oysters are instances of the

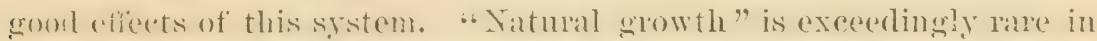
these wateres, and the celebrated stock comes originally from Nerwark liay and the south slope of Lomg Island. There is considirable plant-

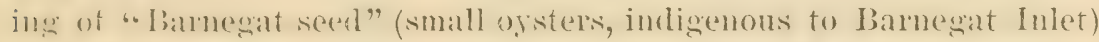

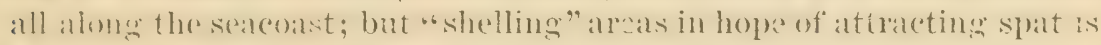

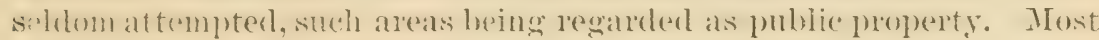
ot the inhabitants of the shores have, however, areas of more or less extent muler cultivation, and the pratice of "freshening" the oysters 
hy cxposing them to fresh water for a short period is prevalent. The planting of Sonthern (Chesalpealie or Virginia) stock is mostly confinerl to the Carpe May district and Delaware Bay, and most of the plants come from the seacoast, about Chincoteagne. The regulations governing the fishery are made loy the towns or comties, and generally permit the leasing, for limited periods, of small areas to residents only. 'The state law prohibits the use of the dredge aud pre-emption of natural beds.

In the Delaware Bay the law permits the leasing of larger areas and the use of the derelge. Dreelging ressels are licensed at $\$ 1$ per ton. A "collector" and "special officer", who execute the laws and collect dues and fines, are elected hy the persons leasing oyster lots. One-halt the money fom linemses, property sold, and fines goes to the "orster find," which is deroted to paying the expenses of guardme the leased beds. The "seed" for these tracts comes usually fiom the matural berls, but some is also importerl from the Chesapealie and Virginia seacoast.

Delaware.-The natural oyster berls of this State lie on the western sike of I selaware Bay, and, thowgh formerly rery prokluetive, do not now pield a lareserop. Probably son areses comprises the total productive area. The state law permits the pre emption of tracets of 15 aceresof of free bottom" for s.s. datural beds are exempted, and citizens of the sitate alome are permittod to "plant" oysters. An oyster guarl-boat is provicled, with officers and crew, and reculations governing the close-time, night-fishing, sc., are enforeel. The natural bexls are worked continnomsly for "seet," lont the major portion of the "planted " oysters come from the Ghesalpeake. The oysters are culled as dicheded, hut the "seed" and small oysters are transferred to the "idle-gromud," a tract where "seed" is growing, instead of being thrown back on the planterl bed. The plantations are located off Little Creek Landing, and no natural berls leagally exist, sonth of a line drawn eastwand from Mahon lives, except in less than 3 feet of water.

Maryland.-The oyster business of this State is practically confuned to drextging the natural beds that exist to an enormons extent in Chesipeale bay and its tributaries. There is little ox no planting or eultivation, the natural areas having in the past supplied all the demands; but of late those areas are becommg much exhansterl, and the diminished quantity and quality of the oysters is camsing weat complatint.

The laws which govern the fishery are, briefly, as follows: Inedging is allowerl from October 1 to May 1. Taking of ogsters in ofher ways fiom September 1 to May 1. I rexlging is not allowed in the rivers or ereelis, or in their months. No steam dredgesare allowed. Alldredgers and "tongers" must be licensed. Tiolations of the law are punished by not more than two years imprisonment nor $\$ 200$ fine. For the enfioreoment of these leandations there is extablisherl a state fishery forec, eom. sisting of one steamer and several small sloups. The officers of this fishery foree and the sherifts amb constables of the diflerent counties are empowered to inake arrests and enforce the law. 
"Tonging," that is, taking oysters hy tongs, is permitted at any point, and small tracts of bottom, contignous to the land of the person desiring to plant or cultirate oysters, may he secured for that purpose; rery little in that line is, however, attempted.

Virginiu.-This State has also extensive natural oyster beds, and, conseruently, but little attention is given to planting and cultiration. Dredging is no longer allowed, but the law on that point is frequently disreganded by the lawless dredging vessels of the bay. A certain amomit of a rude species of eultivation is carried on, consisting merely in transplanting oysters from one locality to another, but the yiehl is inconsiderathe when complared with that of the watmal beds. These, like the Maryland areas, are fast being exhansted by the excessive fishery. Fo "fishery force" is maintained, and the latw is enforced by local peace officers, occasionally assisted by the militia of the State.

None of the remaining Southern States are inportant oyster centers. The fishery is confined to supplyiug the local demands, and no parking or canning is attempted. As a general thing the natural hecis aftorid as many oysters, and those of as good a quality, als is desired. In the nejghberhood of Charleston, South Carolina, Alobile, Alabama, Xew Orleans, Louisiana, and Galveston, Texas, a rude system of cultivation, similar to that of Virginia, is carried on to a limited extent.

On the Pacific coast, cultivators have marle many attempts to introduce the Eastern oyster or that from Mexican waters, but without material success. The Eastern variety will live and increase in size, but does not breed, and unless the supply is continually angmented by fresh inportatious from the Fast the planterl beds grarlually die out.

The following statistical summary from the Cnited States Census Report shows the volume of the oyster industry of the whele conntry.

Table showing, by States, the persons employed, capital invested, and value of products in the oyster industry.

\begin{tabular}{|c|c|c|c|c|c|c|c|c|}
\hline \multirow[b]{2}{*}{ States. } & \multicolumn{3}{|c|}{ Grand total. } & \multicolumn{2}{|c|}{$\begin{array}{l}\text { Persons em- } \\
\text { ployed. }\end{array}$} & \multicolumn{3}{|c|}{ Apparatus and capital. } \\
\hline & 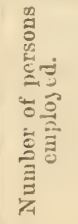 & 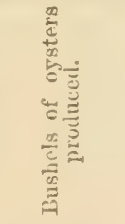 & 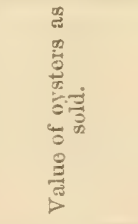 & 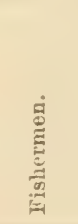 & 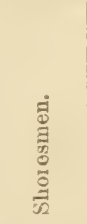 & 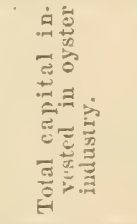 & 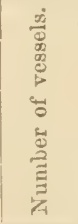 & 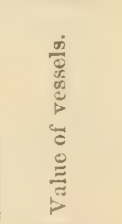 \\
\hline Total .. & 52,805 & $22,195,370$ & $\$ 13,438,852$ & 38,249 & 14,556 & $\$ 10,583,205$ & 4,155 & $\$ 3,528,700$ \\
\hline 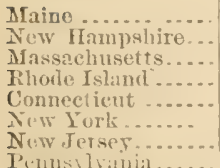 & $\begin{array}{r}15 \\
9 \\
896 \\
6.30 \\
1,006 \\
2,7 \pm 1 \\
2,917\end{array}$ & $\begin{array}{r}1,000 \\
36,000 \\
163,200 \\
336,450 \\
1,013,300 \\
1,975,000\end{array}$ & $\begin{array}{r}a 37,500 \\
6,050 \\
405,550 \\
356,925 \\
672,875 \\
1,577,050 \\
2,080,625 \\
\end{array}$ & $\begin{array}{r}5 \\
6 \\
409 \\
300 \\
672 \\
1,958 \\
2,605\end{array}$ & $\begin{array}{r}10 \\
3 \\
487 \\
350 \\
331 \\
766 \\
312\end{array}$ & $\begin{array}{r}4,210 \\
2,400 \\
303,175 \\
110,010 \\
3(51,200 \\
1,012,0100 \\
1,057,060\end{array}$ & $\begin{array}{r}1 \\
56 \\
100 \\
476 \\
575\end{array}$ & $\begin{array}{r}3,000 \\
227,000 \\
69,000 \\
397,000 \\
530,000\end{array}$ \\
\hline
\end{tabular}

a This quantity represents ouly the enhancement, the first cost being included in the Marj land and Virgimia statisties. 
Table showing, by States, the persons cmployed, capital invested, sc.-Continued.

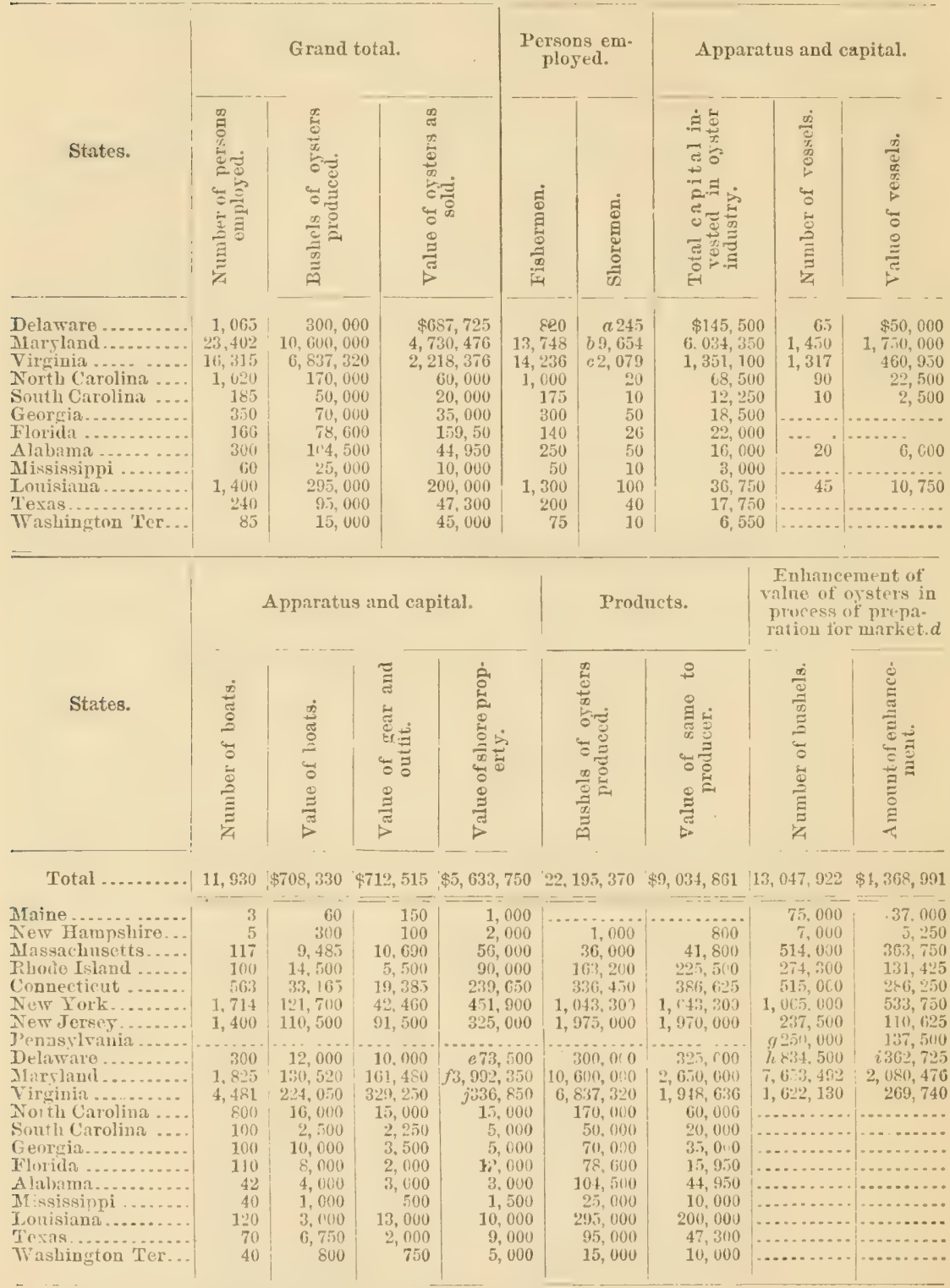

a Of these, 215 are emnlorel in the camnerics at Seaford.

$b$ Of these, 8.864 are + mplutw in the ran ious canneries.

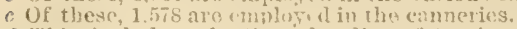

¿ This includes planting, bulding, fitteniug, and transnortation to distant markets in ogster$\mathrm{T}(\mathrm{sin}, \mathrm{l}) \mathrm{s}$

o (of this, $\$ 28,500$ is insested in the cambery interests at. Seaford.

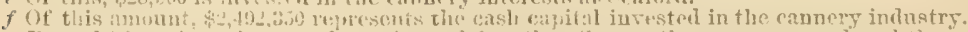

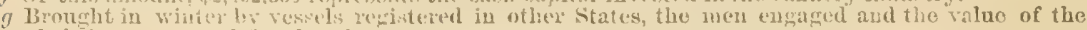

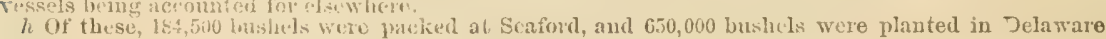
$\mathrm{B}: \mathrm{Y}$.

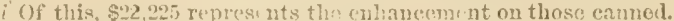

i Of this, $\$ 11 !, 3,50$ represents the cast calutal in the cannery interests, and $\$ 167,500$ the value of buildings and tixtures fur camsing. 


\section{IYya arenaria, Linne.}

This is the "clam" of the Massachusetts coast. The "lons", or "soft clam," of Long Island Somud and the Midille States, and the "Mananose" of the sunthern States. Its range is from the Aretic Orean to South Carolina, but it is rare south of Cape Uatterats. It is particallarly large and abundant in Long Island Sound, and is also fombl on the coasts of Alaska and California. It is fossil in the I'ost-I'lowene formations of New England and the Southern States, and also in the Miocene of Maryland. This species, though fonth on sambly shores in the littoral zone, prefers a bottom where there is a mixture of mul or gravel, or both, with the sand. It lives on outer beaches, but not in loose sands, and generally is most abuudant in the sheltered bats and estuaries. Its burrows are permaneut, and it is usually buried a toot or more below the surfice, its long siphoms enabling it to reach the necessaly food and oxygen at that distance. The specimens of this shell taken from onter sandy beaches are thinner, whiter, ant more resular in form than those found in the estuaries; they are also (on verel with a thin, yellow epidermis. The specimens from the esturates ate rough, mul-eolored, and homely, and might easily be mistalen for another species. The spawning season is during the spring or early summer montlis; the pro. cess of reproduction has not yet been studied, and no definite information is avalable regarding the embryonic or early life of the animal. After they become pereeptible, howerer, they are fomblanchorel to the

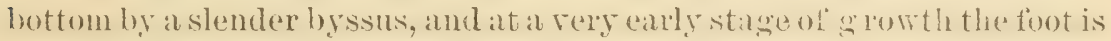
developed, and with it the animal's pomer of lumoming. They usually exist in commmnities, or beds, on the thats, sinking themselves deep in the simd and mud during the winter, and coming nearer the surface as the warm weather approaches. "The clam" is eaten extensirely in the neighborhoorl of the bay of Fundy, and the shell-heaps bear evirtence that this consumption is uot of recent chate but that the Myu arenure furnished the Indians with food centuries ago. Extensive beds oecur at intervals along the coast of Maine, and the mouths of all the riversand estuaries contain this clam to more or lesisextent. It is indered the most important sledl-fish of the State, and the ammul yichl is estimated at nearly 316,000 bushels, valued at about $\$ 8 S, 472$.

The Massadhusets tishery is the one of most conseruence, and the whole coast of that State was at one time saturated with clams, the young sometimes being so abundant as to whiten the beaches and thats; of late years, howerer, this abundance has not been so marked, and the clams are disappearing through orerfishing. The are ordinarily talien by digeing, but on the flats north of Boston, and in the neighborhood of Plymouth amel Duxbury, at one time they were so plentiful that ploms were used in turning them up to the surface.

Though the Mya arenaria is taken to a small extent in Duzzard's Bar, the next point of importance is Xirragansett Bay and the Rhode Island 
shnres. While in Massachusetts Bay the profitable season is during the summer months, in lihore Island the winter's fishing hrings in the largest return; a large number of the inhabitants of the shores being engaged during that season in seemring soft clams. The whole coast of Long Island Sound is prolific, and one or two points are espectially noted for the abundance, or superior size and quality, of the clams nsually fomd. Guiltord, on the Connecticut coast, is especially prominent, the elams from that vieinity sometimes being 6 and 8 inches long, a pound or more in weight, and retailing in New IIaren markets for 81.25 per dozen. These elams are, howerer, only obtained at extremely low tides and are comparatively scarse. A bout 10,000 of the ordinary size are taken per annum, and are sold at from 40 to 60 cents per dozen. All along the sonthern shore of the sound are prolific clamming grounds, the principal product of the fishery being shipped to New York. 'The south shore of the island, especially liockaway Bay, also sends its quota to supply the New York market. New York and Newark Bays fiormerly supplied large numbers of soft clams, but of late years those areas

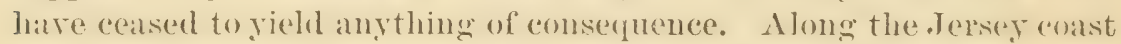
the ammal yield is about 70,000 bushels, valued at about $\$ 00,500$. Sonthward of New Jersey the dlya arenaria ceases to be of eommercial importance, being eaten only by the negroes and a few of the inhabitants of the shores.

During the last few years this mollusk was carried out from the East to San Francisco Bay, aprarently by accident, with a cargo of oysters intended for transplanting. Those taken ont, howerer, were sufficient to abundantly stock the bay, and the soft clam is now found there in large numbers.

There is very little in the methods of taking this species that calls for peenliar apparatus or appliances. A sparde and bucket are the usual implements at the present day, the use of the plow having been but local, and abandoned when the abundance of the erop decreased. At Bridgeport, Conn., it is still nsed by Mr. Iawles, hut only in cultivating; he having instituted a system of cultivation on a seale of considerable magnitude. His method is, briefly, to plow long furrows in the flats, and lay his clams in them, some 6 or 12 inches apart. Some five years or more are necessary before the crop is realized, but it then pays exceedingly well.

The soft elam is very seldom eaten raw, but is cookerl in a variets of ways, usually as sonp or chowder, and frequently fried. Some dealers pickle them, and a small number are salted. They are to be bought in the markets of any of the Middle or New Lngland States, raw, and are usually sold in strings of a dozen connected by a cotton cord.

While extensively eaten, the larger portion of the ammal crop is utilized as bait by the corl and mackerel fishermen. Unless the prospective fishing royage is short, the clams used for this purpose are removed from the shell, salted, and packed in barrels; but when only a short trip is 
undertaken, they are carried fresh in the wells or packed in ice. The saltings are of two kinds: "full salting" and "slack salting," or "covering." In the former method one bushel of salt is allowed to cach barrel; in the littere, only from half a peek to half a bushel. A bout 12 bushels of clams vill make a barrel of salted bait, $\pi$ hich is ralued at 5. . The pratetied of taking mackerel in seines, and the use of the trawls in the coul tishing. which are not baiterl with clams, is interfering with this branch of the soft clam industry; but it is still of considerable importance.

The following is a summary of the annual product of the fishery, and its ralue:

Total number of clams (11ya arenaria) ............. 164, 195, 200

T'otal number of bushels.................... 8:35, 971

Value per bushel (average) $\ldots \ldots \ldots \ldots \ldots \ldots \ldots \ldots \ldots$. \$0.

Total value annual product .................. \$330,523.24

\section{Mactra solidissima, Chemnitz.}

This bivalve is the Mactra giganten of Lamarck, the Muctra similis of Say, and the sppisule soldelissime of Gray and other writers. It is known commonly as the "sea," "surf," or "hen" "lam, the rarious designations being applied indiscriminately. It exists fom Florida and the Gulf of IIexico to Labrador, and is abundant along the entire coatst. It is found fossil in the Post-I']iocene of Matsiachusetts, and anparently in the Hioeene of the Carolinas. The Hectra solidissima propr. erly belongs to sandy shores, and is not often fombl clserwhere, the only otlier locality it seems to faror being the grarelly and shelly bot toms of bays and somuls, where it is eommon and of gxeat size. It exists in sheltered waters and on open beaches, and generally firom low-water mark to 5 and 6 fathoms. It is very abundant ambl larise on the onter beaches of New Jersey and south side of Long Islamd. The shells vary greatly both in size and form; they may be oval, chliptical, triangular, compressed, or swollen, and are sometimes more than 6 inches longy and 5 broad. As the siphon-tubes are rery short, it does not burrow yery deeply, thongh its large and muscular foot enables it to do so cuickli Large numbers are thrown up on the beaches by every storm, to be utilized as food by the birds, and as manure by man.

The "sea-clam" is not of commereial importance sonth of New Tersey, and probably is more extensively songht in the Cape Cod region than elsewhere. There they are worth s:; per harrel, but sell in the Boston market, when fresh, at 3 ; in New York markets they are rare. Their consumption as food is confined to the coasts prineipally, owing to the "ase with which the superior" "longe clam" and "round clain" can be obtained, and on aceount of the tonghness of the flesh of the large animals. The young of this species are, howerer, quite equal in flaror and quality to any clam of the coast.

While not holding a high place as an eclible mollusk, the sea-clam 
oreupies an inportant position in the latit-suply? of the "Banks" fishermen, and is somght mamly for that purpose. The clams are seculed by means of heary, varomsly shaperl, iron rakes, having fiom 1 in to 25 lange teeth, and fitted with wooklen poles or handles firom :00 to 30 foet lung. The fishing is andered on at. low water in chepths of ahout s feet, and the catch is worth from 25 to 28 cents a bushel. The clams are salted, packed in barrels, and dispatehed to the rarious fishing ponts, such as the town on Cape Con, Boston, and Gloucester. Alout threefourthe of the ammual erol' goes to buston. In the fill 16 bushels of clams alle lexpluires to fill oine barrel with "meats"; hut in the sirring only 12 bushels are necessary. The actual cost of a barrel of clams, salted and parked, in lowton, is ahout 5.5.7.5. The shells and also sold

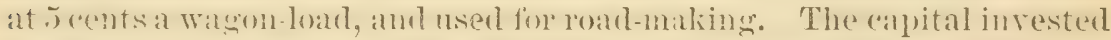
in the business watio, in 1359), \$10,6400, and between 2000 and 300 boats were employed.

\section{Cyprina islandica, Lamarck.}

This clam is the "sea-clam" or "false quahaug." It is found in deep Water, from Block Islanel to the Aretic. In depth it varies from 6 to 100 fathoms. It has not been found yet as a fossil in North America.

The cyprinu islundica is rarely eaten, indeed rarrly fombl, but is arailable for foul or bat. It is easily distingusher from the true quahaug (Tenus mercenaria) by its brown epislermis.

\section{Ensatella americana, Verrill.}

This is ons of the spocies of the wemus solen, and has been rapiomsly

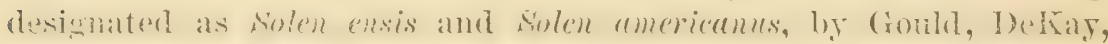
Adams, Linné, and others. It is the "razor-clam" or "razor-fish" of commerce; and is also called the "razor" and "knile-handle." Its distribution is retensive, the animal beine fonnd from Florida to Labrador, amd it is common alomer the whole coast, especially in Lome Island Somm, and at creat Wege Habor, New Jersey. It is fossil in the PostPliocene lepositsof Mane, Massachusetts, Tiremian, and South Camolina, in the P'liocene of Sonth Carolina, and in the Miocene of Haryland, and North and Sonth Carolina.

The Ensatella americana is an inhabitant of sand flats and bars, where the water is pure; it is fomme also, thouen not so eommonly, on

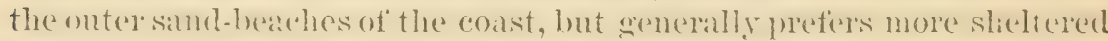
localities. It usually exists at or just below low-water mark, and its large elliptical-shaped burrows, extruding "2 or is feet into the sand, aro easily reengnized when the tikle is out. If the holes ale apporoboherl with cane at such times, an inch ol two of the shell ean be seen project. ing above the surfice; lont the slightest jar of the sand is sufileient to semel the whole colong to the bottoms of the burrows; and the al:arm once given it is useless to attempt to dig them ont, for the animals can 
penetrate the sand much faster than the spade can follow them. Eren when partially uncovered they often hold themselres so firmls in the holes by means of their muscular foot, that the body can be entirely withdratrn from the shell before the hold is relaxed. As their siphons are rery short, they are obliged to come to or near the surface in order to obtain the necessary supplies of oxygen and food. Therefore, though the animal may be out of sight, fet it is probably only sunk a short distance in the sand, and a sudden thrust of a spade obliquely across the direction of the burrow will frequently unearth the clam. The disadvantages of the short siphons are, however, made up by the great, activity of the animal and the momterful power of its foot, which is its excavating implement and organ of locomotion.

The razor-clam is eaten to some extent along the coasts of Long Island, Long Island Sound, Massachusetts Bay, and coasts of New Jerser. It. is to be found in the New Yorle markets, but the trate is not extensive, the sweetish flavor of the flesh being mpalatable to the majority of people. It is nsed as bait, also, esperially abont Cape Cod and on the south shore of Loug Island, and is devoured by several fishes, surh as the skattes and tantog, that seem to have the power of rooting it out of the samcl. The New Jersey longshoremen also claim that the "winlice" (Fulgur coricu) has the power of pulling the "razor" from its burrow and devouring it.

\section{Venus mercenaria, Linné.}

This is the "quahang," or "round clam," sometimes linown as the "hard clam." It is found from Florida to Massachnsetts Bay, and thence" northwarl, though rare aud local, to the Gulf of Saint Lawrence. It is very eommon from Vineyard Sound sonthward, and is found fossil in the Post-I'liocene formations of Massachusetts, Gardiner's amel Nantuelet rslands, Virginia and Sonth Carolina, and in the Miocese of Maryland, Virginia, and North and South Carolina. This species lives relietly on muldy and sandy flats, just below low-water mark; but it is often found above that line, and between tides is frecuently left bare. It is more abundant in estuaries than elsewhere. It ean burrow but a short dis. tance, having short siphon-tubes, and it is often seen erawling abont on the surface by means of the broal, muscular foot with which it excatrites its burrow. The shells are varialole in color and form, and early writers hare made many varieties of this species on that account. Some forms, especially those growing in estmatries, have dull, thick, rongh shell., sometimes white, sometimes stainerl, while shells from nuter, sandy beaches are thinner and more delicate, have raised, concentrie ridgess or ribs, and are marked with strealis of brown or redl. Other shells have marked darli blue or purple discolorations out side the pallial line; others are of deal white. All these have been described as distinct species, but there is no structural difference; and intermediate forms are to be found in every locality. As these clams grow old, the valres $228 \mathrm{~A}-4$ 
become rounded, and are then known to the fishermen as "sinb-nosed" or "bull-nosed" elams, and are sometimes a pound or more in treight. Their thesh is then a dirty yellow, having lost its clean, white appearance. Little is known, except by analogy, of the embryolugy of the "quahaug" or of its rate of growth. Ingersoll states that the merlium sized sent to market are five years old, while M[essrs. Fonte \& Co., of New Haven, state that the medium-sized clams are but two rears old. Their rate of growth no doubt depends upon the locality; where there is an abundant supply of food and lime, and the animal is protected, the srowth will be rapid; when otherwise, the growth will be slow. The rate of growth is also said to intluence the shape of the shell, the slower the progress the greater being the convexity of the valves. During the winter the "quahaugs" retire into the mul, disappearins from the surfice, and in the spring reappear in time for the principal fishery, which begins then and extends throughout the summer, thus alternating with the oyster season.

The "quahang" fishery is rery extensive, this bivalve being, next to the oyster, the most important on the coast; but the implements and methods aresimple in the extreme. Many clams are gathered by hand as they crawl on the flats; many more are taken with straight rakes, curved drag-rakes, and dredges. Oyster-tongs are also occasionally used, bit not freguently, as the clams do not live in sufficiently close communities to make touging profitable. The rakes are more geuerally employed than any other implement, and in form and rharacter they vary with the locality. Some are merely slight modifications of the garden rake; others are more elaborate, having curved teeth or long poles, fitting them for dragging or dredging rather than shallow-water raking. Specimens of the different varieties are exhibited, but, lile the other cham fisheries, that of the "quahaug" utilizes many implements designed originally for other purposes, such as the sea-moss rakes, spades, shorels, \&e.

"Count" clams, the largest size, bring the best prices, and in the neighborhood of New fork sell for \$3 per barrel, wholesale. It takes 800 "counts" to make a barrel; and as 3 to 4 barrels, or 2,100 to 3,200 clams, is a good day's catch, some idlea of the productireness of the New Jersey flats and coast is gained from the foregoing. Smaller sizes are sold at 60 eents or $\$ 1$ per bushel, depending on the size, and some are taken so small that 2,000 are required to fill a barrel; these, when about one inch in diameter, are called "tea-clams." Another name is "Little Neck," derived originally from a neek of land on the north shore of Long Island, known as Little Deck, whose clams had a smperior flaror; but the demand for a young, small, and tender clam which has sprung up of late years, and was supplied from the Little Neck stock, has eansed dealers generally to apply the term "Little Neck" to all small clams. They are used prineipally for pickling.

The fishery is not an expensive one, the whole ontfit of the "clammer" 
not requiring an expenditure of orer $\$ 150$, including boat, ralie, aud baskets, aud the pursuit is natmally followed by the poorer class of people-men who are employed by the oyster-dealers in winter and are out of work during the summer. The prineipal depots are New York and Philadelphia, but a large number of clams are consumed throughout the interior of the New England and Niddle States, and every seahordrd town sends its quota to supply the demand. To the southward of the Delaware and Chesapeake this consumption diminishes very fast, that of all the Southern States being estimated by Ingersoll at not more than 50,000 bushels, valued at $\$ 20,000$.

The summary of the annual product and value of the "Quahaug" fishfishery for the whole coast is:

Number of clams taken, $326,245,800$.

Number of bushels, 1,087,486.

Value, $\$ 657,747$.

Mytilus edulis, Linné.

This is the ordinary "black" or "edible" mussel. It is found from the Aretic Ocean south to North Carolina, on the east coast, and south to Monterey on the west coast of the United States. It is very abundant from New Jersey northward and is found fossil in the P'ost-Pliocene formations of most of the localities north of Rhode Island. It is identical with the common mussel of Europe in all respects.

The Hytilus edulis is most abundant in the shallow and brackish waters of hays and estuaries, but flourishes well in anj situation where there is a little mud and some solid object to which it can attach itself. The coasts of New Jersey and Long Island are especially aldapted to it, and it is found in those regions in immense numbers. It has also increased of late years in Chesapeake Bay and trilntaries. It grows very rapidly, reaching maturity, under faropable circumstances, in one season. It is uot confined to shallow waters, but exists in the deep as well, having been taken off the coast of Maine in 40 and 50 fathoms. The shells of those living in sheltered localities and on sandy bottoms are, howerer, much more delieate in texture and brilliant in color than those inhabiting exposed situations. The former are often beautifully marked with alternating bands of different eolors or are pale yellow or translucent horn color. The latter are thicker, of a dull brown or bluish-black colvr, and often much distorted.

The breeling season begins early in the spring, and Verrill states that lie has found immense numbers of the size of a piu's head as early as the mildle of April. The mussel attaches itself to its support by means of a "hysusu" or silli-like threal, spun from the foot, and as it has the power of relinquishing its hold on the euds of the threals at any time, it can change its location at will, and by means of the delicate byssus, can ("ran climb the perpendicular sides of piles and rocks. On the muddy bottoms of balys and sounds these mussels frequently exist in large 
patches or beds, and such local ities are the farorite resorts of the prediatory fishes, molluslis, erustaceans, and radiates. The star-tishes especially freguent these areas and destroy immense numbers of mussels. All tha injurious Gasteropods prey upon them more or less, wherever found, aud the tantog, drum, and other fishes devour the adults, while the scup and like smaller fish feed upon the young.

Though used as food to a limited extent on both coasts of the United States, there is no organized fishery devoted to the capture of the mussel. In common with many other shell-fish not known in the markets, they are eaten oceasionally by the inhabitants of the coast, and of late year's some trade is springing up on the coasts of Connecticut and Long Island. Most of the mussels sold for food go to New York and are there disposed of in the natmal state, but more frequently are boiled and pickled. Inbabiting the interior of the shell of the mussel is a small messmate-the Pimotheres maculatus, or mussel-crab-which, like the little oyster-crab, is a delicions morsel. While not as yet extensively utilizerl as food, the mussels, like many other shell-fish, are frequently used for fertilizing the grombl, the farmers of Long Istaml and New Jersey securing them by the wagon-load for that purpose. In time, however, the will probably ocecupy as prominent a place in the food supply of the American seaboard as they do on the coasts of Europe. The value of the mussel fishery in $1879-80$ is estimated by Ingersoll at \$37,000, which represents a yield of 600,000 bushels.

\section{Modiola plicatula, Lamarck.}

This species, known as the Ribbed-mussel, is found from Georgia to Casco bay, Naine, and exists, thongh more rare and local, further north. It is very abundant from Vineyard Sound to the sonthward, especially along the coast of New Jersey, and has been reported of late as increasing in Chesapeale Bay. It is more abmulant in the neighborhood of estuaries and salt marshes, or on mudty shores, and is usually fomed about high-water mark, where it is left uncovered for a greater part of the time by the tirle. Along the erlges of marshes they are sometimes crowled so thickly as to form a stratum finches or more in thickness. Like the Morliole mortiolus, this species is not of eommercial importance. It is very seldom eaten by man, though it is devoured by many tishes, especially the "drums," and by star-fish and the carnivorous Galsteropods. In company with an allied species, the Modiola hematus, and the Mrytilns edulis, it is used quite extensively on the New Jersey coast for fertilizing ground. The presenee, which is by no means infrequent, of this mussel on an oyster-bed, is undesirable, the bunches and masses held together by the byssus, attracting the varions enemies, that, though they came for the mussels, remain to derour the more valuable oysters. 


\section{Modiola modiolus, Turton.}

This, the great "horse-mussel," is found from (ireenland southward to Tuw elesey on the Atlantice, and from the Aretic sonth to Mnonterey on the Parcifie coast. It is more abundant north of Cape Cod than to the sonthwarl, and is fonm firom low-water mark to $s 0$ fathoms. It is fossil in the P'ost. P'locene formations of Massachusetts and Canada. The lorise-mussel is usually located in erevices between rocks, or berlded in the giavel; aud along the coasts is almost entirely condined to rocky bottoms. Its larege size and brown, hairy epirlermis, sufliciently distinsnish it from other species. Though oreasionally used for bait, and arailable for food, it is at present of no commercial importance.

\section{Pecten irradians, Lamarck.}

This is the common "scallou" of the easteru coast. It extends from Texas and the Gulf of Mexico to Cape Cod, and is occasionally found noith of that point. It is fossil in the Post-Pliocene of North Carolina ancl Forila, in the P'liocene of Somth Carolina, and in the Miocene of Maryland.

The "scallop" is found on sandy and shelly bottoms, in sheltered localites, but usually prefers those points where the eel-grass abounds and where there is more or less mul on the bottom. During the summer the young shells may be seen clinging to the eel-exass or sea-weed in large numbers, and in the antumn the mature animals are fommd in the shallow waters along the shores in great abundance. Also after storms great quantities are thrown upon the beaches. But the seallop is momarlic; no one locality can be sure of its crop, no matter how almmolut the animals may have ben luring the previous seasons. Indecd, some of the harbol's of Lomg Island are visited by seallops in numbers but once in form and five years, and at other points the appearance and lisaplearance is irregular. Culikemany other bivalre molluskis, the I'ecten irradiens is not fixed immorably to some foreign object; is not anchored by a network of threads or "byssus," nor is it compelled to creep slowly ahome the surface of the mud or sand by means of a "foot" howerep" muscular and strons. On the contrary, it is a very activeswimmer' and by opening and energetically closing its valves, it forces the water fiom the sill carrity, the reaction driving the animal backwal through the water. It is rery watehful, yuickly pereeiving an enemy, and when alarmed, deserts the matted leares of eel-grass, its usual habitation, and takes to the buttom. In moving fiom place, to platee, the animals make a suc(exsion ef leaps to the surface ealch time arlvancing some yalds on their jomrney, and great schouls of those curions shells are sometimes seen thus darting about in the water. The spawning takes place during the summer, and continues as late as September. The size of the shells at that time is shown in the series illustrating the rate of growth. The glowth doring the autumn months is quite rapid, but it is claimed that 
further advancement is stopped as soon as the winter sets in. About the middle of July or first of August following, when the seallops are one year old, the grow th begins again, and is very great during the succeeding antumn months. At this age they are marketable. The increase in size after the first year is not very great, and scallops two and three years old are not only dificult to find, but are worthless for marliet purposes. It is the general impression among the fishermen that the animals see but one spawning season, and die during the succeeding winter. Nodoubt the excessive fishery has had itsinfluence in producing this opinion, and probably the scarcity of scallops two aud three years old, is dne, to some extent, to the persistent search for those of a marketable age, or those fifteen and eighteen months old.

The method of conducting the fishery varies somerhat with the locality, but is essentially as follows: The fishing boats, especially in Narragansett and Peconic Bays, which are the principal centers of the industry, are usually cat-boats, small sloops, or sharpies, and are prorided with six, eight, ten, and twelve dredges or scrapes of the patterns exhibited. These are put orer from the sides and stern of the boat, and towed after her as she sails backward and forward over the drelging-ground. As soon as a dredge is full it is hanled in and emptied on the "culling" board, which extends across the boat, and then put over again. The scallops are then separated from the other matter brought up by the dredge. In calm weather smaller boats or dories are employed, one man pulling and another tending the dredges, and occasionally, in shoal and clear water, a dip-net with a long handle is used. The best grounds for dredging are those where there is ouly a thin layer of mud over the sand. The only part of the scallop that is used is the great white abductor muscle, known to the fishermen as the "eye" or "heart." This is extracted from the shell, the process being termed "eutting out", by a dextrousmotion, or rather combination of three motions of the short knife of the opener. It is wonderful to witness the extraordinary rapidity with which the "cntting out" is done; but thongh the process appears less fatiguing than oyster-opening, it is not so rapid, the latter process requiring but two motions instead of three. In the early part of the season a bushel of scallops will yield one-half gallon of meats, but in December the animals hare increased so much in size, that a full gallon is produced from the same quantity. The "meats" are packed in wooden boxes or tubs, and transported, if possible, withont ice, as contact with that article impairs the Haror. The trade is confined principally to to the New Lingland States and New York markets. The meat has a fresh, sweetish, and somewhat insipid flavor, not usually appreciated by the uneducated palate. It is selolom eaten raw, hut is usually cooked, being fried or boiled; some also are piekled. In addition to its commercial importance, the I'ecten imatiuns furnishes food to many important edlible fishes, such as the cod and others; it is also preyed upou by all the earnivoroms (Galsteropods, and by the star-fish and crabs. 
The principal fishing localitios on the east coast of the Uniterl States are Buzzard's Bay, Massachusetts, Greenwich, Rhode Island, Peconic Bay, Long Island, and Morehead City, North Carolina. On the west coast, Wilmington and San Diego; but there is no regular trade in seallops in those localities.

In 1880 the product and value of the industry was:

Number of gallons, 72,063.

Value, $\$ 25,825.20$.

Pecten tenuicostatus, Mighels.

This is the "Great" or "Giant" seallop, and is found from New Jersey to Lahrador, but is rare and local south of Cape Cod. It is generally found in comparatively deep water, existing in the bay of Fundy in over 100 fathoms, but may be taken in as little as 2 and 3 fizthoms. This species is not abumdant nor of commercial importance. It is atrailable for food, howerer, and is occasionally used as such. It is distinguished from the common scallop by its size, smooth surface, and pectlliar, reddish-brown epidermis.

\section{Argina pexata, Gray.}

This is the Ared pexate of Say and the "Bloody Clam" of the fishermen. It is found from Florida and northern shores of the Gulf of Mexico to Cape Cod, and is local but rare, north of that point. The proper home of this animal is in off-shore shallow bottoms. It is sometimes found in other places, attached by a brssus, but not generally. It is oecasionally used for bat, but otherwise is not of importance. The term "blovdy," applied to them, and the seurphence transwerwa a similar shell, is due to their discharge of a sanguineons liquor when opened. They are thus, and by their rough, dark, hairy epidermis, readily distinguisherl.

The varions speeies of star-fishes are supposed to prefer the "bloody" clams to all other food, and the presence of the Argina pexata on or about an ofster-bed is therefore a welcome sight to the planter.

\section{Glycimeris generosa, Gould.}

This is a Pacific coast species, known as the "Geoduck" or "Giant Clam", haring an extensive range, but not existing in verr large numbers. It is found in sheltered localities on the coast, from Inget Sound to San I)iego; it lives in rather deep water, rarely being found except below extreme low-water mark. Its long siphous permit great depth of the burrows, which usually penetrate the sandy-mud bottoms in which the animatl lives, some two or three feet. The northern animals are the largest and most abundant.

The Geoduck is said to be of rery fine flaror, but too rich to be used constantly as fool. One animal is sufficient for an entire meal. Owing to its scarcity, it is not at present eaten extensively. 


\section{Siliqua patula, Dixon.}

This species, the "Flat Razor Clam", is found from Alaslia to California, and is especially abundant along the northern coast. It grows to a length of four or five inches, and is covered with a gloss, rich brown enidermis. It does not burrow very deep, aud is esteemed do. licious food, but is not extensively used.

\section{Platyodon cancellatus, Conrad.}

This is the "I)ate Fish", a species closely resembling Mya arenarin, found along the coast of California from San Franciseo southwand. It exists in great abundance in Baulinas Bay and at Santa Barbara. Its habits are essentially those of the "soft clam", and it forms one of the staple food shell-fish of the Pacific coast.

\section{Zirphaca crispata, Mörch.}

This mollusk, though widely distributer along the Atlantic coast of the Uniterl States, is not of commereial importance, while on the Pateifie coast, where it is known as the "Date Fish," it is fomd in the marliets and eaten by numbers of people. The l'acific variety is, howerer, considrably langer than that ordinarily found on the eastern coast. It is a northern species, not ocemring south of Bastern Comnectient, and extending to the Gulf of St. Lamrence, in the Atlantic, and oni the west coast being rarely found south of Sin Francisco. It is fossil in the Post. I'lincene of Maine. All the Pholedide are borers, and Z. crisprete is no exception, but it is not very destructive, usually preferring mud and clay to wood.

\section{Macoma nasuta, Conrad.}

This species, called the "Tellen", is very common on the P'arific coast, and has a wille range, extending from Kamschatkat to Mexico, but is rare sonth of San Diegro. It is abundant in San Franciseo bay, and it was evidently eaten largely by the aborigines, as the shell-momuls in the rieinity of the bay are largely eomposed of shells of this species. It indabits muddy tlats, hurrowing quite deeply, and reaches the water by its two small, perl siphoms. The usual length is two inches. It is eaten on the Pacific coast by all classes.

\section{Tapes staminea, Conrad.}

This speries, linown as the "Carpet-Shell", "Tittle-Neck Clam," and "Mard-shelled Clam", is abmolant on the who!e Californian coast, and is found in all the mallets. Tomales Bay furnishes a larege number, as do other points where the animal is to some extent plotected, as at Baulinas. It is msmally foumd between tide-malks, huried one or two feet in the bottom, which may be either muddy or stony. This and other species designated as "Little-Neck Clams" oceupy a similar place 
in San Franciseo marlets to that of the small-sized Fenus mercenarill, used so extensively in the Eastern States.

Tapes lacinula, Cpr., is a closely allied species, and has about the Same distribution as $T$. stemince. No distinetion is male in the markets

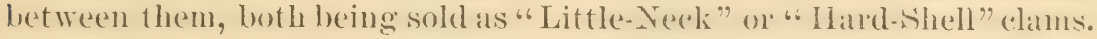
They are the most abundant and extensively nserl of all the clams indigenons to the coast; but of late, since the introduction of the Hyat arencria, they have been supplanted in the markets to a great cxtent extent by that auimal.

Chione suceincta, Val., and Chione simillimu, slyy., are also known in the markets as "Little-Neck" clams, but are not so abundant as Tepes. They live on sandy beaches on the California coast, and especially in Monterey liay and other sheltered localities, but are not found in sulticient numbers to be of much importance as a food supply.

\section{Saxidomus aratus, Gould.}

This is the "Round Clam" of the Pacific coast. It is found from San Francisco to the southward to Sin Diego, but is not abundant. MIonterey and San Diego produce it in largest numbers. It is probally only a southern variety of the northern shells of this genus.

\section{Teredo.}

There are four species of the genus Teredo found on the coast of the Cruited States, and also an allied species, the Eylotrya fimbriate, of Jefireys, having similar habits. The Teredo nerelis, Limer, is the most abmolimt, and extends from Vineyard Somel to Florida. The Terdo megoture, Ianley, is found firm Massachusetts Bay to Sonth Carolina. The Teresto Thomsonii, Tryon, is indigenons, but its rlistribution has not

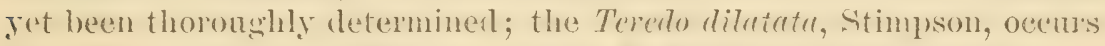
fiom Inssachusetts to Florida, and the .X. fimlwiute has the same range. 'These creatures are nsually known as ship-worms and iuhabit submerged wood-work, floating or stationary, and freduently do gieat damage. An instance is reended of the piles of a wharf at Cape Ifemy having been destroyed in nine days by their ravages. Though they burow into all submergerl wook-work, it is for protection and not for food, and the exarations once made are neatly lined by the animal with sheily material. While at the surfice the holes are very small, having been mate by the young Terdos; as they go deeper, they gradually grow larger, and are sometimes 10 inches in length and one-guarter inch in diameter. The tubes, howerer they may enter the wood, unally tmm, at a short distance from the surfinee, in a direetion parallel with the grain. The hurrow of one animal nexer interferes with, or crosses that of amother, and a thin partition of wood is always left between the tubes. The temblency to follow the gram is not due to neeessity, for the Tererio can bore throngh the harlest knots; nor is it necessary that the tubes should be straight, for they aro often very croolied aud tortuous. 
The animals grow very rapidlỵ, attaining maturity in one season. The young are poduced in Maj and in the summer months, and during the early stages of development are free-swimming. While embryonic, they have olwans both of sight and hearing, and are also provided with a "foot"; hut as they derelop, their powers of sight and swimming" are lost. When they finally locate themselves they are about the size of the head of a pin, but this size rapidly increases. The destructive powers of the "ship-worm" are well known, and probably there is no effective remedy except that in use for protecting the bottom of ressels, viz., copper sheathing. The various yoisonous snbstances applied to timber are of no use, as the animal does not live on the woor, but uses it as a location only. The only remedies likely to suceed are those which will prevent an entrance. The United States Engineer Colps has experimented, at the Delaware Brakwater, for some years, with wood that hat been treated with creosote, and the experiments appear to have becu succossful; hut whether the success is accidentul or not has not yet been determined.

\section{Martesia cuneiformis, Gras.}

This is another species of the genus Pholas, and is linown as the "Poring Pholad," of the oyster-beds. It is very commin and abundant in Chesalpeake Bay, and is found in any waters to which Chesupeake oysters hare been tramsmorted. It lives in small chambers, which it excavates in the shells of oysters or other bivalves, but rarely does any serious damage, the eflorts of both oyster and pholad being directed to the prevention of complete penetration of the valve. The pholad appears to flourish best in brackish water, and in Chesapeake Day was most aloundant on oyster-beds that had evidently deteriorated. Their presence, therefore, in large numbers is considered to be one of the indications of deterioration. 


\section{CATALOGUE.}

\section{MOLIUSCA CEPHALOPODA.}

SQUIDS AND CUTTLES.

Ommastrephes illecebrosa, Terrill. Squid, Flying Calamary, Sea-amow. Northeast coast of North America.

33655. New England coast. United States Fish Commission.

33660. Eastport, Maine. United States Fish Commission.

Loligo pentii, Lesueur. Common Squid. South Carolina to Massa. chusetts Bay.

33656. New England coast. United States Fish Commission.

Loligo brevis, Blainville. Calamary or Ink-fish. Southern and southeastern coasts of the United States.

3:3661. Coast of Louisiana. United States Fish Commission.

Arehiteuthis princeps, Terrill. Giant Squid. Coast of Newfomulland and adjacent waters. Model made by Mr.J. H. Emerton, from moasurementsand descriptions of a Squid thrown ashoreat C'atalina, Trinity Bay, Newfomalland, September 24,1875 . Principal dimensions: Length of body, $S$ feet; Length of head, 1.1 feet; length of tentacles, 30 feet; length of lst pair of arms, S.2 feet; length of 21 pair of arms, 9. feet; length of :id and the pair of arms, 11 feet; greatest diameter of body, 21 feet.

Octopus punctatus, Gabb. Octopus, or Devil Fish. Northwest coast of the United States. Model made by Messrs. J. H. Emerton and IVm. Palmer, from inspection of small specinens, and pul, lished measurements and descriptions. Length of longest arms, 16 feet; length of shortest arms, 13 feet; diameter of circle swept by arms, 18 feet.

\section{MOLLUSCA GASTEROPODA. SEA SPAILS.}

Useful for food or bait.

Luccinum undutum, Linné. Whelk. Long Island Sound to Greenland. Not common south of Cape Cod, except in deep water. Very abundant on coast of Maine.

3363\%. Vincyard Sound. United States Fish Commission. 
Fulgur carien, Conmal. Periwinkle, Winkle, and Wrinkle; also Ribbon Whelk.

(See "Injurious Gasteroporls.")

s'ycotypus conaliculatus, Gill. Periwinkle, Winkle, and Wrinkle; also Hairy Whelk.

(See "Injurious Gasteropods.")

Iittorina littorea (Limé), Menké. Pennywinkle, or Sea Suail. Northeastern coast, from Connecticut to Nova Scotia.

33654. Wood's Holl, Mass. United States Fish Commission.

Purpura lapillus, Lamarek. Sea Snail.

(See "Injurious Gasteropods.")

Ilyanassa obsoleta, Stimpson. Sea Snail. Whole southern and eastern coast of the United States, but rare and local north of Cape Coll.

33633. Vineyard Sound. United States Fish Commission.

Lunatia heros, Adams.

(See "Injurious Gasteropods.")

Neverita duplicata, Stimpson.

(See "Injurious Gasteropods.")

Haliotis (sereral species). See below.

Useful by producing Pearl shell.

Trochiscus norrissii, Sowerby. Turban Shell.

32830. Coast of California. H. Hemphill.

Pomaulax undosum, Chemnitz.

32832. Coast of California. Natural state. II. Hemphill.

32831. Coast of Califoruia. Prepared to show pearly layers. H. Hemphill.

Huliotis (rarions sprecies). Abalones or Sea-Lars. Pacific coast of the United States from San Franciseo southwarl. Coast of Lower California and Mexico. Not common south of Magdalena Bay, Lower California.

Haliotis kamchatianu.

32838. Coast of Alaska. J. G. Swan.

Haliotis corrugata, Gray. Rough Sea-Ear.

32890. Coast of Southern Califoruia. W. H. Dall.

Haliotis rufescens, Sowerby. Abalone or Red Sea-Ear.

32900. Monterey, California. H. Hemphill.

Haliotis cracherodii, Leach. White Abalone.

32823. Coast of California. Paul Schumacher.

32899. Monterey, California. H. Hemphill. 
Haliotis splendens, Roe. Splendid Sea-Ear.

32821. Coast of California. Paul Schumacher.

32898. Coast of Sonthern California. H. Hemphill.

Manufactured state of Haliotis shell.

29302. Furnished by A. B. de Frece \& C̣o., 428 Broadway, Now York.

29248. Furnished by Harvey \& Ford, Pliladelphia, Pa.

Mannfactured state of varions American Pearl shells derived from Gasteropods.

29301. Variety furnished by A. B. do Frece \& Co., 428 Broadway, Now York.

Affording dye, as well as ornamental.

Phyllonotus brassica, Lamarek. Purple-shell.

32911. Coast of Lower California. W. H. Dall.

Phyllonotus bicolor, Valeneiennes. Purple-shell.

32912. West const of America. W. H. Dall.

Affording cameo and porcelain stock.

6968. Cameo-shell (Cassis rufa), used for cameo cutting. Florida. Dr.

Wm. Stimpson.

Injurious, by destroying food-producing mollusks.

Fulyer carica, Conrad. Periwinkle, Winkle, and Ribbon- Whelk. Eastern coast of the United States from Floridla to Care Cod; abundant in Vineyard and Long Island Sounds.

33635. Vineyard Sonnd. Uuited States Fish Commission.

33458. Oyster Bay, Long Island. H: A. Townsend.

3345:3. East Greenwich, R I. A. A. Wilson.

33613. Egg capsules. East Greenwich, R. I. A. A. Wilson.

Syeotypus cunaliculutus, Gill. Periwinkle, Winkle, Wrinkle, and Irairs Whelk. Whole eastern and southern coasts of the United States as far as Cape Cod; abundant in. Vineyard and Long Island Sounds.

33401. Oyster B $\mathrm{y}$, Long Island. H. A. Tomnsend.

33454. East Greenwich, R I. A. A. Wilson.

33611. Great South Bay. Blue Point, Long Island. F. C. Dayton.

33636. Vineyard Sound. United States Jish Commission.

33612. Ligg capsules. Great South Bay. F. C. Daytou.

Urosalpinx cinerea, Stimpson. Drill or Rough Whelk. Eastern coast of the United States to Massachusetts Bay; local farther north to the Gulf of Saint Lawrence; west coast of Florida ; abundaut from Virginia to Cape Cod, especially on oyster-beds.

33632. Vineyard Sound. United States Fish Commission. 
Purpure lapillus, Lamarek. Drill or Whelk. Long Island Sound to Aretic Ocean; rare and loeal sonth of Cape Cod; ahundant on northern coasts of New England and Nova Scotia.

33652. Wood's Holl, Mass. United States Fish Commission.

Lunatia heros, Artams. Sea Suail. Georgia to Gulf of Saint Lawrence and Labrador; abundant and large on coasts of New Jersey and Long Island.

33653. Vineyard Sound. United States Fish Commission.

Neverita duplicate, Stimpson. Sea Snail. Massachusetts Bay to Northern Florida; Northwestern Florida to Yucatan; local and uncommon north of Cape Cod; abundant fromNantucket southward.

33455. East Greenwich, R. I. A. A. Wilson.

33610. Great South Bay, Blue Point, Long Island. F. C. Dayton.

33657. Vineyard Sound. United States Fish Commission.

Crepidula plana, Say. Sea Snail or Slipper Shell. Massachusetts Bay to Florida; northern shores of Gulf of Mexico; local northwarl of Massachuset ts to Gulf of Saint Lawrence; common in Vineyard and Long Island Sounds.

33658. Vineyard Sound. United States Fish Commission.

Crepidula fornicata, Lamarck. Sea Snail or Boat Shell. Caseo Bay, Maine, to Florida; northern shores of Gulf of Mexico; local north of Massachusetts; abundant from Vineyard Sound southward.

33659. Vineyard Sound. United States Fish Commission.

While the above speeies of Crepidula are neither directly injurious nor heueficial, they are often associated with destructive Gasteropods. In addition, their absence from an oyster-bed is one of the many indieations of its deterioration.

\section{MOLIUSCA LAMELITBRANCHIATA.}

\section{BIVALVE SHELL-FISH.}

Affording food or bait.

Ostrea virginica, Gmelin. American Oyster.

- Map showing general distribution along the eastern coast of North America.

- Map showing location of oyster-beds along the coast of Prince E. Wward's Island, Nova Scotia, New Brunswiek, and shores of the Gulf of Maine and Massachusetts Bay.

- Series of maps showing the distribution of orsters, and approximate areas and positions of natural and artificial oyster-beds, along the coast of the United States, from Cape Corl to the lio Grande. 
On these maps, red indicates natmal oyster ground; blue, artifucial or. "planted" beds; pruple, interspersed natudal and artifieial beds ; and jink, "scattered" oysters. Thestrength of the tintiug indicates, rough!y, the quality, and the variations in color the character, of the several areas.

\section{Cutalogue of maps of oyster beds.}

\section{Locality.}

Cape Corl Bay (extinet beds)

South coast, Massachusetts, "Nantucket Shoals to $1-80,000$ Muskeret Channel."

South coast, Massachusetts, Buzzard's Bay, "Mus- | 1-80, 000 kesct Channel to Buzzard s Bay."

Nirragansett Bas, "Cuttyliunk to Block Island" .. 1-80,000

Long Island Sound, "Point Judith to Plum Island". - 1-80, 000

Long Island Sound, "I'lum Island to Weleh's $1-80,000$ Point."

Loug Island Sound, "Welch's Point to New York". 1-80, 000

South const of Long Island, "Block Island and 1-80,000 Jlontauk Point."

Soutl coast of Long Island, "Great South Bay and | 1-80, 000 Firo lslanil."

"New York I3ar and IIarbor" ................... 1-80,000

Coast of Now Jersey, "Sandy Hook to barnegat In- 1-80, 000 let."

Coast of Now Jersey, "Barnegat Inlet to Absecom | 1-80, 000 Inlet."

Cnast of New Jersey, "Absocom Iulet to Cape 1-80,000 May."

Deliware Bay. "Delaware Entrance" ........... 1-80,000

Delamare Bay and River

Sea-coist uf Araryland, "Cape May to Isle of Wight". 1-80,000

Sea-coast of Marylaud, "Isle of Wight to Chinco- $1-80,000$ teanue Inlet."

Sea-cosst of Virginia, "Chincoteague Inlet to $\Pi$ Ior $\mid$ 1-80, 000 Island,.'

Sere-const of Virrinia, "Пog Island to Cape Ienry" . 1-80,000

"Entrance to Chesapenke Bay, Hampton Roads, 1-80,000 Ace."

Chesapeake Bay, "York River to Pocomoke Sound". 1-80, 000

Chesapeake Bay, "Poeomoke Sound and Entrance 1-80,000 to Potomac liver.

Chesapualio Bay, "Potomac River to Choptank 1-80,000 liver."

Chesaneake Bay, "Choptank River to Magothy $\mid$ 1- $\delta 0,000$ liver.'

Chesapeake Bay. "Magnthy River to Head of Bay". 1-80, 000 P'otomac Riser, "Entrance to Pinos Point" ........ 1-60,000 Potomae River, "Piney Point to Lower Cerlar 1-60,000 I'oint."

Rappaliannock River, "Entrance to Deep Creek" .. 1-60,000 Iappalianuock River, "Deep Creek to Occupacia 1-60,000 creek."

York River, "Entrance to King"s Creek"

York Kiver, "King's Creek to WW est l'oint" "....... 1-60,000

James River, "Newport News to Point of Shoals" $1-40,000$ strait."

James liver, "Point of Shoals Strait to Sloop $1-40,000$ Point."

Sonth Carolina, "Tincah Bay" ................... 1-40,000

South Carolina "Iinll's Bay" "

South Carolina, "Long Island to Hunting Island" . 1-80, 000

Si uth Carolina aud Georgia, "Hunting Island to $1-80,000$ Ossabaw Tsland."

Georgia, "Savamnah to Sapelo Island"

Georgia, Sapelo Island to Amelia I-land" .......... 1-80,000

Georgia and Florida, "Cumberlayd Sound and St. $1-80,000$ Jolus's liver:"

Florida, "St. Anguatine Inlet to Fialifax Rirer"... 1-80, 000

Florida, "Halifax River to Mosquito Lagoon"...... 1-80, 000

Florida, "Indian River" ......................... $1-80,000$

Florila, "T'tumpa Bay" . ..................... 1-80,000

I'lorda, "Appalachicoli Bay to Cape San Blas".... 1-80,000

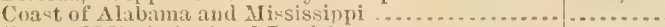

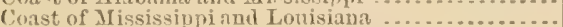

Tixas, "Galveston I3ay to Orster Bay"

Texas, "Oysicr Bay to Mata rorda Bas"............ 1-80, 000
Compiler.

Mr. Edward P. Cook.

Mr. Viual N. Edwards.

Do.

Shell-Fish Commission of Phorle Islant and Lient. Francis Winslow, U.S. N.

Shell- $\mathrm{F}$ ish Commission of Connecticut and Lieut. Francis WVinslow, U.S. N.

Shell-Fish Commission of Connecticut and Lieut. Francis IVinslow, L.S. T.

Shell-Fish Commssion of Compecticut and Lient. Fr. ncis Winslow, U.S. N.

Licut. Francis WV inslow, U.S. N.

Do.

Do.
Do.

Midshipman J. B. Blish, U.S. N.

Do.

Do.

Do.

Lieut. Francis Winslow, U. S. N. Do.

Do.

Do.

Do.

Do.

Do.

Do.

Do.

Do.

Do.

Do.

Do.

Do.

Do.

Do.

Do.

Do.

Mr. G. S. Hobbs.

Do.

Do.

Do.

Do.

Do.

Do.

Do.

Mr. Silas Stearns.

Do.

Do.

Do.

Master C. McR. Winslow, U. S. N. Do. 


\section{Ostrea Tirginica, Gmelin. American Oyster.}

\section{BIOLOGY.}

SERIES OF ILIUSTIATIONS OF TIE IMBRYOLOGY OF THE AMERICAN OYSTER, PIRPARED FOR THE MAITLAND JISH COMMISSION BY DR. W. K. BliOOKS, PII. D., OF JOHNS HOPKINS UNIVERSITY, BALTIMORE.

\section{Explanation of the figurcs.}

Unless the contrary is stated, the fignres are drawn with a magnifying power of 250 cliameters; Zeiss. F. 2, but it was necessary to amplify the sketches considerably in order to reproduce, by the process of photoengraving, the features which this magnifying power rendered visible, and the figures as they are produced are of about twice the diameter of camera sketches made with the same magnifying power.

'The first thirty-two figures show the process of segmentation. Figure 1 is an egg at the end of the first period of rest; Figures $2,3,4,5,6$, and 7, the changes during the first period of activity; Figures $8,9,10,11,12$, and 13, the changes during the second period of rest; Figures 14, 15, and 16. those which take place during the second period of activity; 17,18 , and 19 , those which take place during the third period of rest; 20 and 21 , during the third period of activity; 22 , during the fourth period of activity; 23 , duriug the fifth period of activity, and the remaining figures show more widely separated stages. In all the figures of segmentation, except $\$ 3,30$, and 31, the formative pole is above and the nutritive pole below.

Figure 1.-Ergrs two hours and seven minutes after fertilization. It is now perfectly spherical, with an external membrane, and the germinative vesicle is not visible.

Figure 2.- The same egg two minutes later. It is now elongated; one end is wider than the other, and a transparent area at the broad end marks the point where the polar globules are about to appear. At the opposite end the external membrane is wrinkled by waves which run from the nutritive towards the formativo pole in rapid succession for abont fifteen seconds.

Figure 3.-The same egg two minutes later.

Figure 4.-The same egg two minntes later. The yolk has become pearshaped. The polar globule has appeared at the formative pole, in the middle of the broad end of the pear, and the nutritive end of the egg is now less granular than the formative end.

Figure 5. - The same egg two minutes later. Three equidistant furrows have made their appearance, separating it into a single mass at the nutritive pole, and two at the formative pole. At this stage the three masses are about equal in size.

Figure 6.-The same egg two minntes later. The first micromere, $c$, is now perfectly separated, and smaller than the second, $b$, and each is smaller than the macromere, $a$.

Figure 7. - The same egg one minute later. Both micromeres are separated and are spluerical, as is also the macromere. This stage ends the first period of activity.

Figure 8.-The same egg forty-five seconds later. The two micromeres have begun to fuse with each other, and the second micromere, $b$, is also partially fused with the macromere, $a$.

Figure 9.-The same egg one minute later. The first micromere, c, has also begun to unite with the macromere. 


\section{Ostrea Virginica, Gmelin. American Oyster-Continued.}

Figure 10.-The same egg one minute later. The line between the second micromere and macromere has disappeared, and the first micromere, $c$, now projects from one end of the elongated mass formed by the union of the spherules $a$ and $b$.

Figure 11.-The same egg three minutes later. The fusion of $a$ and $b$ is now complete, and a large transparent vesicle is now visible in the first micromere, $c$, and another in the compound mass, $a b$.

Figure 12.-The same ogg two minutes and thirty seconds later.

Figure 13.-Another egg, about two minutes later. This is the true resting stage, at the end of the second period of rest. The two vesicles have become irregular. The remains of an external membrane adhere to one side of the egg.

Figure 14.-The same egg seven minutes later than Figure 13. The compound mass, $a$ and $b$, is elongated, the first micromere, $c$, is well defined, and waves travel from the nutritive towards the formative ends of the two masses. Two segmentation nuclei occupy the positions of the large vesicles of earlier stages. This stage is the beginning of the second period of activity.

Figure 15.-The same egg one minute later. The second micromere, $b$, is now well defined, as well as the first.

Figure 16.-The same egg one minute later. This stage marks the end of the second period of activity. The formative end of the egg is now occupied by four micromeres, two of which seem to be the products of the division of the first micromere, $c$, and two of them the products of the second, $b$.

Figure 17.-The same egg two minutes later, at the commencement of the third period of rest. The second micromere, $b$, has again begun to fuse with the macromere, $a$.

Figure 18.-The same egg three minutes and thirty seconds later. The second micromere is no longer separated from the macromere, and mass, $a$ and $b$, formed by their union is nearly spherical.

Figure 19.-The same egr two minutes and a half later, at the end of the third period of rest, viewed at right angles to Figure 18.

Figure 20.-The same egr thirteen miuutes later, and in the same position as Figure 18. The spherule, $c$, of figure 19 has divided into two, and the second micromere, $b$, has become prominent, so that there are five micromeres at the formative pole.

Figure 21.-The same egg one minute later, and in the same position as figure 19.

Figure 22.-The same egg in the position of Figure 20, fifteen minutes later than Figure 21, and in the fourth period of activity. There are now seven micromeres at the formative pole, six on one side of the polar globules and one, the second micromere, $b$, on the other.

Figure 23.-The same egg twenty-one ininutes later, viewed from the side opposite the second micromere. The cells which have been formed by the division of the micromeres of the stage $19 \mathrm{now}$ form a layer, the ectoderm, which rests, like a cap, on the macromere, $a$.

Figure 24.-The same egg five hours and fifteen minutes later, in the same position as Figure 22, but not quite so much magnified. On one side the polar globule is still separated from the macromere, $a$, by a siugle spherulethe second micromere, $b$. Opposite this the growing edge, $g$, of the ecioderm is spreading still farther down over the macromero. At the point $g$, and at four other points, are pairs of small cells, which have evidently been formed by the division of the large spherules.

Figure 25.-Another egg at about the same stage. 


\section{Ostrea Tirginica, Gmelin. American Oyster-Continued.}

Figure 26.-The egg shown in Figure 24, fifty-five minutes later. The macromere, $a$, is almost covered by the ectoderm, and the second micromere, $b$, has divided into a number of spherules. At the growing edge, $g$, an ectoderm spherule is seen separating from the macromere.

Figure 27. -A similar view of an egg twenty-seven hours after impregnation. The macromere is almost covered by the ectoderm, $e c$, and is not risible in a side surface view. At $g$ is an ectoderm spherule, which is separating from the macromere.

Figure 28.-Optical section of the same egg; ec, ectoderm; en, macromere, divided into two spherules. No segmentation cavity can be seen in a normal egg at this or any of the preceding stages.

Figure 29.-View of the nutritive pole of an egg a few hours older.

Figure 30.-View of the formative pole of a still older egg.

Figure 31.-Optical vertical section of a somewhat older egg, figured with the polar globule above and the ectorlerm to the right. The egg is now flattened from above downwards, and is disk-shaped in a surface view. The macromere has given rise to a layer of larger graular cells, which are pushed in so as to form a large cup-shaped depression. The more transparent ectoderm, ec, now carries a few short cilia scattered irregularly, and the two layers are separated from each other by a segmentation cavity. This figure is in Plate III.

Figure 32.--Surface view, and

Figure 33.-Optical section of the embryo at the first swimming stage. The ectoderm has folder upon the endoderm, so as to form a prinitive digestive cavity, with an external opening, $g$. The cilia of the velum have now made their appearance around the area occupied by the polar globnle. This was not present in the egg from which the figure was drawn, but it was seen in other eggs, and is shown in a later stage of another embryo, Figure 6.

Figure 34 and Figure 35.-Two surface views of the embryo shown in Figure 32.

Figure 36.-An older embryo, in the same position as Figures 32 and 33. The external opening of the primitive digestire tract has closed up, and the two valves of the shell have appeared in the place which it had occupied. The endoderm has no connection with the exterior, and no central cavity could be seen.

Figure 37.-A somewhat older embryo, figured with its dorsal surface above. There is a large, central, ciliated digestive cavity which opens exterually by the mouth $m$, which is almost directly opposite the primitive opening, the position of which is shown by the shell, s.

Figure 38.-A similar view of a still older embryo. The shell, s, has increased in size, and the digestive tract has tro openings, the mouth, $m$, and the anus, an, which are very near each other on the ventral surface.

Figure 39.-The opposite side of a still older embryo, in which the body wall begins to fold under the shell, to form the mantle $m$.

Figure 40.-Dorsal view of an embryo at about the same stage.

Figure 41.-Dorsal view of an embryo at the stage shown in Figure 38, with its valves extended; rs, right valve of shell; $l s$, left valve of shell; an, anus; $a$, anal papilla; ma, mantle; $v$, velum ; $b$, body cavity; st, stomach.

Figure 42.-View of left side of a still older embryo; $i$, intestine. Other letters as in Figure 41.

Figure 43.-Dorsal view of an embryo six days old, swimming by the cilia of its velum.

Figure 44.-View of right side of another embryo at the same stage; $m u$, muscles; $l$, liver. Other letters as in Figure 41. 
Ostrea Tirginica, Gmelin. American Oyster-Contiuned.

Figure 48. - The seminal fluid of a ripe male oyster, mised with water, and seen with a power of 80 cliameters. Zeiss. ก. 2 .

Figure 49.-Fluid from the ovary of a ripe female oyster, seen with the same magnifying power.

Figure 50.-Seminal tluid of a ripe male ofster, magnified 500 diameters.

Figure 51.-Egg a few minutes after mixture with the male fluid magnified 500 diameters.

Figure 52.-Egg about thirty minutes after fertilization magnified 500 diameters.

Figure 67. - Section of a portion of the visceral mass of a male oyster magnified 250 diameters. The surface epithelium of the borly is shown at the lower end of the figure. Above this is a loose, thick laser of wrinkled celle, which have the appearance of adipose cells from which all the fat has been remored. Above this layer is a large duct, lined with epithelial cells, and filled with ripe spermatozoa, which have been poured into it from two follicles which communicate with it on each side. Above this are sections of a number of the follicles of the testis, in three of which the contents are figured.

Figure 53.-Section of a portion of the visceral mass of a female oyster magnified 250 diameters; $a$. epithelium of the surface of the body; $b$, layer of connective tissue; c, layer of wrinkled cells, which are probably fat cells, from which all the fat has been removed; $f$, sections of ten ovarian follicles; $e$, the ovarian eggs.

Figures 54-66.-Abnormal or direct form of segmentation.

SERIFS OF PHOTOGRAPHS ILLUSTRATING ATtaCHMENT AND GROTTH OE "SPAT" AND OYSTERS. INVESTIGATIONS OF FRANCIS WINSLOW, U. S. N., ASSISTANT U. S. COAST AND GEODETIC SURVEY, 1879.

SERIES OF SPECMMENS ILLUSTRATING ATTACHMENT OF SPAT.

333391. Jamaica Bay, L. I. C. E. Vreeland.

33519. Saunders' Point, Povidence River. Soft bttom. Jason S. Pierce. 32802. Bayou Cook, Lonisiana. Alex. Gordon.

32796. Blue Point, Lorg Island. "Seed" ou leather shoe. B. J. M. Carley. 33618. Oyster Bay, Long Island. Growth on stone. H. A. Townsend. 32973. Long Island Sound. Growth on part of stone jug. Hoyt Bros. 32792. Blue Point, Loug Island. Growth on Mactra shell. B. J. M. Carley. 32958. Long Island Sound. Growth on various "stools." Hoyt Bros. 32958. Long Island Sound. Growth on "King erab." Hoyt Bros. 32458. Loug Island Sound. Growth on stone. Hoyt Bros.

33390. Huntington Harbor, Long Island. Growth on stone. Wilson Beardsley.

32793. Blue Point, Long Island. Growth on stone. B. J. M. Carley.

32970. Long Island Sound. Growth on bottle. Hoyt Bros.

32971. Long Island Sound. Growth on stome. Hoyt Bros.

32894. Blue Point, Long Island. Growth on bone. B. J. M. Carley.

3151. Long Island Sound. Growth on stone. Hoyt Bros.

33619. Patchogue, Long Island. Growth on clay pipe. F. C. Dayton.

38932. Blue Point, Long Island. Growth on boot-leg. B. J. M. Carley.

33572. Potomac River oyster transplanted June, 1882, to Delaware Bay.

Peculiar growth. Thos. J. Love.

33573. Delaware Bay. "Set" five months old. Thos. J. Love.

33620. Providence River. Growth on crab. Monsell \& Dewing.

32794. Blue Point, Long Island. Growth on rubber boot. B. J. M. Carley. 
Ostrea Virginica, Gmelin. American Oyster-Continued.

32974. Blue Point, Long Island. Growth on rubber shoe. B. J. M. Carley. 33621. Maurice Cove, Delaware Bay. Growth on twig. Thos. J. Lovo. 32789. Blue Point, Long Island. Rosette of oysters. B. J. M. Carley. 32895. Blue Point, Long Island. Growth on rubber shoe. B. J. M. Carley. 33102. Presby's Creek, Va. G. W. Harvey.

33622. Maurice Cove, Delaware Bay. Growth on bottle neck. Thos. J. Love.

33459. Delaware Bay. Cluster of young oysters. S. I. Middleton. 32969. Long Island Sound. Growth on crab. Hoyt Bros. 33648. Great South Bay, Long Island. "Set" two months old. Monsell \& Dewing.

SERIES OF SPECIMENS ATTACHED TO SLATE COLLECTORS USED BY MR. J. A. RYDER, DURING HiS INYESTigations AT ST. JEROME'S CREEK, MD., 1880.

33623. Placed Angust 3, taken in September 16, 1880, 44 days.

33624. Placed July 31, taken in October 21, 1880, 82 days.

33625. Placed August 3, taken in October 21, 1880, 79 days.

33626. Placed Augnst 3, taken in October 21, 1880, 79 days.

33627. Placed August 3, taken in October 21, 1880, 79 days.

33628. Placed September 10, taken in October 21, 1880, 41 days.

SERIES ILLUSTRATING CHARACTERISTICS OF SEVERAL SPECIES OF OYSTERS.

Ostrea edulis Linné. European oyster.

32811. North Sea.

Ostrea borealis, Lamarck. Canadian oyster.

32810. Buzzard's Bay, Mass. Dr. Wm. Stimpson.

Ostrea lurida, Cpr. California oyster.

32879. Crescent City, Cal. W. H. Dall.

Ostrea Virginica, Gmelin. American or Virginia oyster.

33096. Saint Gerome Creek, Md. G. W. Harvey.

SERIES ILLUSTRATING VARIATIONS FROM $O$. borealis to $O$. virginica and vice versa.

33098. Tangier Sound, Md. G. W. Harrey.

33381. Oyster Bay, Loug Island. Eighteen months old. Planted one year on hard bottom. H. A. Townsend.

32808. Coast of Florida. Raccoon oysters. Lieut. Kossuth Niles, U. S. N. 32961. Long Island Sonnd. Two to three years old. Hoyt Bros.

33382. Huntiugton Harbor, Long Island. From hard bottom. Wilson Beardsley.

32960. Long Island Sound. Oue to two years old. Hoyt Bro's.

32805. Appalachicola Bay, Fla. Lieut. Kossuth Niles, U. S. N.

33387. Huntington Harbor, Long Island. From soft bottom. Wilson Beardsley.

32965. Long Island Sound. Three to four years old. Hoyt Bros.

33102. Presby's Creek, Va. G. W. Harvey.

33407. Osster Bay, Loug Island. From haxd bottom. H. A. Townsend. 33379. Oyster Bay, Long Island. From muddy bottom. H. A. Townsend. 
Ostrea Tirginica, Gmeliu. American or Virginia oyster-Continuer.

SERIES SHOWING PECLLIARITIES OF GROWTH DUF TO ATTACHMENT OF SPAT.

33103. York River, Virginia. G. W. Harvey.

33102. Presby's Creek, Virginia. G. W. Harvey.

33101. Nasawaddox Creek, Virginia. G. W. Harvey.

32974. Long Island Sound. Hoyt Bros.

32797. Blue Point, Long Island. B. J. M. Carley.

33492. Bridgeport, Conn. Point No Point "seed." Wheeler Hawles.

33386. Huntington Harbor, Long Island. From soft bottom. Wilson Bearlsley.

33383. Huntington Harbor, Long Island. From hard bottom. Wilson Beardsley.

33588. Indian River, Florida. G. S. Hobbs.

33393. Shrewsbury River, New Jersey. E. G. Blackford.

33390. Huntington Harbor, Long Island. Wilson Beardsley.

33104. Cherrystone Creek, Virginia. G. W. Harvey.

33417. Seaville, New Jersey. J. W. Gandy.

33590. Vicinity of Savannah, Ga. G. S. Hobbs.

33095. Rappahannock River, Virginia. G. W. Harvey.

33565. Poquonock River, Connecticut. J. P. Bogart.

33406. Freeport, Long Island. E. G. Blackford.

33592. Vicinity of Charleston, S. C. G. S. Hobbs.

33569. Maurice River Cove, Delaware Bay. Thos. J. Love.

33100. Little River, Maryland. G. W. Harvey.

33380. Oyster Bay, Long Island. H. A. Townsend.

33396. Bridgeport, Conn. Guilford River "seed." Wheeler Hawley.

33418. East Greenwich, R. I. A. A. Wilson.

33098. Tangier Sound, Chesapeake Bay, Maryland. G. W. Harvey.

33380. Oyster Bay, Long Island. H. A. Townsend.

33598. Corpus Christi, Texas. C. McR. Winslow, U. S. N.

33377. Oyster Bay, Long Island. H. A. Townsend.

SERIES SHOWING PECULIARITIES OF GROWTH DUE TO ABNORMAL INFLU-

ENCES OR CHANGES OF POSITION SUBSEQUENT TO TIME OF ATTACHMNTT.

32791. Glenwood, Long Island. B. J. M. Carley.

32795. New York Bay. B. J. M. Carley.

33406. Freeport, Long Island. E. G. Blackford.

33331. Oyster Bay, Long Island. Planted one year ou hard bottom. H. A. Townsend.

33382. Huntiugton Harbor, Loug Island. From hard bottom. Wilson Beardsley.

32786. New York Bay. Growth in still water. B. J. M. Carley.

33392. Patchogue, Great South Bay, Long Island. E. G. Blackford.

33569. Maurice River Cove, Delaware liay. 'Thos. J. Love.

33427. East Greenwich, R. I. A. A. Wilson.

33403. Bridgeport, Conn. "Planted ojsters." Wheeler Hamley.

33394. Great Sound, sea.coast of New Jersey. J. W. Gandy.

33589. Vicinity of Savannah, Ga. G. S. Hobbs.

33393. Shrewsbury River, New Jersey. E. G. Blackford.

33412. Jamaica Bay, Loug Island. E. G. Blackford.

33410. Rockaway Inlet, Long Island. E. G. Blackford.

32787. Blue Point, Long Island. From a tide-way. B. J. M. Carley. 
Ostrea Tirginica, Gmelin. American or Tirginia oyster-Continued.

33102. Presby's Creek, Virginia. G. W. Harrey.

33386. Huntington Harbor, Long Island. Wilson Beardsley.

32808. Coast of Florida. Raccoon oyster. Lieut. Kossuth Niles, U. S. N.

33599. Blue Point, Long Islaud. F. C. Dayton.

33651. Cobb's Island, sea-coast of Virginia. Nathan Cobb.

32813. Nova Scotia. From a tide-way. J. R. Willis.

SERIES ILLUSTRATING GROWTIL ON SOFT BOTTOM.

33379. Oyster Bay, Long Island. H. A. Townsend.

32959. Long Island Sound. Hoyt Bros.

32920. City Island, Long Island Sound. B. J. M. Carley.

33095. Rappahanuock River, Virginia. G. W. Harvey.

33599. Blue Point, Long Island. F. C. Dayton.

SERIES ILLUSTRATING EFFECT OF SOFT MUDDY BOTTOM UPON INTERIOR OF SHELL AND DEPOSIT OF NACRE.

32807. Coast of Florida. Lieut. Kossuth Niles, U. S. N.

33101. Nasawaddox Creek, Virginia. G. W. Harvey.

33102. Presby's Creek, Virginia. G. W. Harvey.

33100. Little River, Maryland. G. W. Harvey.

33590. Vicinity of Savanuah, Ga. G. S. Hobbs.

32103. York River, Virginia. G. W. Harvey.

33392. Patchogue, Long Island (Blue Point). E. G. Blackford.

32806. Cat Point, Appalachicola Bay, Florida. Lieut. Kossuth Niles, U.S.N.

33651. Cobb's Island, sea-coast of Virginia. Nathan Cobb.

SERIES ILLUSTRATING VAIIATIONS IN COLOR OF EXTERIOR OF SHELL.

33379. Oyster Bay, Long Island. H. A. Townsend.

33571. Potomac River natives, transplanted to Delaware Bay in June, 188\%. Thos. J. Love.

33528. New Haven, Conn., natives transplanted to Narragansett Bay in spring of 1882. Jason S. Pierce.

33393. Shrewsbury River, New Jersey. E. G. Blackford.

33588. Indian River, Florida. G. S. Hobbs.

32919. Cow Bay, Long Island. B. J. M. Carley.

32784. Prince Edward's Island (var. borealis). Mr. Dawson.

32933. Chesapeake Bay. T. B. F'erguson.

32799. San Diego, Cal. (Ostrea lurida). H. Hemphill.

33407. Oyster Bay, Long Island. From hard bottom. H. A. Tornnsend.

32960. Long Island Sound. Hoyt Bros.

32814. Rhode Island. Col. Totten.

33408. Oyster Bay, Long Island. From hard bottom. H. A. Townsend.

33406. Freeport, Long Island. E. G. Blackford.

3278\%. New York Bay. B. J. M. Carley.

33380. Oyster Bay, Long Island. H. A. Townsend.

33640. Coast of California (Ostrea lurida). R. E. C. Stearns.

SFRIES ILLUSTIRATING GEOGRAPHICAL VARIETIFS.

Coasts of New Brunswick, Maine, Massachusetts, and Rhode Island.

32783. Miramichi River, New Brunswick. W. H. Dall.

32785. Shediak, New Brunswick. W.H. Dall. 
Ostrea Firginica, Gmelin. American or Virginia oyster-Continued. 33092. Shediak, New Brunswick. G. F. Mathew. 33093. Buctouche, New Brunswick. G. F. Mathew. 32978. Sheepscot River, Maine. From extinct beds. R. Dixon. 33555. Sheepscot River, Maine. From extinct beds. Dr. C. A. White. 32810. Buzzard's Bay, Massachusetts (var. borealis). Dr. Wm. Stimpson. 33448. East Greenwich, R. I. A. A. Wilson.

\section{Providence River, Fhode Island.}

33518. Natives, transplanted in 1881 to soft bottoms. Jason S. Pierce.

33523. Natives, three years old, transplanted when two years old to soft bottoms. Jason S. Pierce.

33524. Natives; old. Jason S. Pierce.

33530. Natives from Jolly Banks bed, hard bottom. Jason S. Pierce.

Coast of Connecticut and Norti shore of Long Island.

32790. Greenwich, Conn. B. J. M. Carley.

33528. New Haven, Conn., three years old, transplanted to Providence River in spring of 1882. Jason S. Pierce.

\section{Bridgeport, Conn.}

33492. Point No Point. "Seed." Wheeler Hawley.

33488. Housatonic River. "Seed." Wheeler Hawley.

33496. Point No Point. "Seed." Wheeler Hawley.

33396. Guilford River. "Seed." Wheeler Hawley.

33403. Cultivated oyster twelve to fifteen years old. Wheeler Hawley.

33391. Two years old; transplanted to Jamacia Bay, Long Island, when six months old. Cornelius Vreeland.

\section{South Norwalk, Conn.}

3295\%. One year old. Hoyt Bros.

32962. Three years after transplanting. Hoyt Bros.

32966. Five to twenty years old. Hoyt Bros.

32972. Hoyt Bros.

\section{Nortr COAST OF LONG IsLaND.}

\section{Huntington Harbor.}

33382. From hard bottom. Wilson Beardsley. 33386. From soft bottom. Wilson Beardsley. 33390. Natural growth. Wilson Beardsley.

\section{Oyster Bay.}

33377. Planted on hard bottom. H. A. Townsend.

33376. Planted on hard bottom. H. A. Townsend.

33381. Planted on hard bottom one year. Eighteen months old. H. A. Townsend.

33408. Natural growth on hard bottom. One year old. H. A. Townsend. 33407. Natural growth on hard bottom. H. A. Townsend.

33378. Planted on soft bottom. H. A. Townsend.

33379. Natural growth on soft bottom. H. A. Townsend. 
Ostrca Virginica, Gmelin. American or Virginia oyster-Continued.

32781. B. J. M. Carloy.

Cow Bay.

32812. "Cove." B. J. M. Carley.

32919. "Mill pond." B. J. M. Carley.

32779. Loyd's Harbor. B. J. M. Carley.

32791. Glenwood. B. J. M. Carley.

\section{SOUTH COAST OF LONG ISLAND.}

Great South Bay, Patchogue and Blue Point Distriots.

32914. "Seed." B. J. M. Carley.

32777. B. J. M. Carley.

33392. E. G. Blackford.

Oakdale.

33411. E. G. Blackford.

Freeport.

33406. E. G. Blackford.

Jamaica Bay and Rockaway Inlet.

33410. "Rockaway." E. G. Blackford.

33412. "Jamaica Bay." E. G. Blackford.

Vicinity OF NEW YORK AND COAST OF NET JERSEY.

New York Bay.

32782. B. J. M. Carley.

32780. B. J. M. Carley.

Shrewsbury River.

32778. B. J. M. Carley.

33393. E. G. Blackford.

Barnegat Inlet.

335.28. Illustrating growth of spat and barnacles. Allan Neill.

33559. Very old. Allan Neill.

33417. J. W. Gandy.

Seaville.

33465. Natives, three years after transplanting. Peter Watkins.

33467. Natives, one, two, three, five and six years after transplanting. Peter Watkins.

Somers' Point.

33480. Natives, one, two, and three years old. H. H. Vansant.

Lake's Bay.

33499. Five years old. Alex. Fish.

Ocean View.

33471. One to three years old. J. C. Sharp. 
Ostrea Tirginica, Gmelin. American or Virginia oyster-Continued.

Cape May.

33452. Cape May seed. J. W. Gandy.

\section{Delaware Bay.}

Maurice River Cove.

32915. Three years old. B. J. M. Carley.

32568. "Extras," five years old. Thomas J. Love.

33569. Peculiar growth. Thomas J. Love.

\section{Arnold's Point.}

33577. After transplantation for six months to Maurice River Cove. Thomas J. Love.

33575. "Culls," after transplantation for six months to Maurice River Cove. Thomas J. Love.

Chesapeake Bay and seacoasts of Maryland and Virginia.

Chesapeake Bay.

32933. State of Maryland.

32954. Herring Bay, Maryland. E. G. Blackford.

33100. Littlo River, Maryland. G. W. Harvey.

33096. Saint Gerome Creek, Maryland. G. W. Harvey.

3:3099. Point Lookont Creek, Maryland. G. W. Harvey.

3:3097. Deep Creek, Virginia. G. W. Harvey.

33095. Rappahamnock River, Virginia. G. W. Harvey.

33102. Presby's Creek, Virginia. G. W. Harvey.

33104. Cherrystone Creek, Virginia. G. W. Harvey.

33101. Nasawaddox Creek, Virginia. G. W. Harvey.

33103. York River, Virginia. G. W. Harvey.

33506. Chesapeake oysters, four years old, transplanted in 1881 to Lake's Bay, New Jersey. Alex. Fish.

33481. Chesapeake oysters, transplanted for one and two years to Somers' Point, New Jersey. H. H. Vansandt.

33561. Chesapeake oysters, transplanted to Barnegat, New Jersey. Allan Neill.

\section{Potomac River.}

33516. Transplanted to hard bottom, Providence River, Rhode Island, in the spring of 1882; will not live through the winter. Jason S. Pierce.

33571. Transplauted in June, 1882, to Delaware Bay. Thomas J. Love.

\section{Tangier and Pocomoke Sounds.}

32976. Pocomoke Sound. E. G. Blackford.

39738. Tangier Sound. E. G. Blackford.

33098. Tangier Sound. G. W. Harrey.

33512. Transplanted to hard bottom, Providence River, Rhode Island, in the spring of 1882. Will not live through the winter. Jason S. Pierce. 
Ostrea Tirginica, Gmelin. American or Virginia oyster-Continued.

Sea Coast.

33505. Hog Island oysters, four years old, transplanted in 1881 to Take's Bay, New Jersey. Alex. Fish.

33470. Hog Island oysters, three years after planting. Peter Watkins.

Coast of Soutil Carolina, Georgia, and Flomida.

Vicinity of Charleston, S. C.

33591. Bored by Cliona. Two and a half years old. C. C. Leslie.

33592. Two and a half years old. C. C. Leslie.

33593. From Wadmelaw River. Cultivated. Four years old. C. C. Leslie.

33594. From Togodo River. C. C. Leslie.

Vicinity of Savannah, Ga.

33589. Two and a half years old. G. S. Hobbs.

33590. Four years old. G. S. Hobbs.

\section{East coast of Florida.}

33588. Indian River. Natives. G. S. Hobbs.

Trest coast of Florida.

32806. Cat Point. Lieut. Kossuth Niles, U. S.N.

32807. Lient. Kossuth Niles, U. S. N.

32805. Appalachicola Bay。 Lient. Kossuth Niles, U. S. N.

32808. Raceoon oysters. Lieut. Kossuth Niles, U. S.N.

Const of Louisiana and Texas.

32800. Timbalier Bay, Louisiana. W. Alex, Gordon.

32801. Southwest Pass, Louisiana. W. Alex. Gordon.

32802. Bayon Cook, Louisiana. W. Alex, Gordon.

32803. Four Bayous, Louisiana. W. Alex. Gordon.

32804. Grand Lake, Louisiana. W.Alex. Gordon.

33597. Galveston Harbor, Texas. Master C. McR. Winslow, U.S.N.

33598. Corpus Christi, Tex. Master C.McR. Winslow, U.S.N.

Pacific Coast of the Unitidd States.

Ostrea lurida, Cpr.

32879. Crescent City, Cal. W. H. Dall.

32809. Shoalwater Bay, Washington Territory. H. Hemphill.

32799. San Diego, Cal. H. Hemphill.

33640. R. E. C. Stearns.

Ostrea Virginica, Gmelin.

32798. San Francisco Bay, transplanted from Newark Bay, New Jersey. H. Hemphill.

SERIES ILLUSTRATING TRADE CLASSIFICATIONS.

"Cullers."

32916. Cow Bay, Long Island. Three years old. B. J. M. Carley.

32965. Long Island Sound. Threo to four years old. Hoyt Bros. 


\title{
Ostrea Virginica. Gmelin-Continued.
}

\author{
"Box."
}

32917. Cow Bay, Long Island. Threo years old. B. J. M. Carley. 39y64. Long Island Sound. Four to six years old. Hoyt Bros.

Single extra.

32918. Cor Bay, Long Island. Four years old. B. J. M. Carley.

Double extra.

32776. Com Bay, Long. Island. B. J. M. Carley,

Extra.

33568. Maurice River Cove. Five years old. Thos. J. Love.

SERIES ILlUStratiNg RAVAGES OF ENEMIES.

32956. Long Island Sound. Killed by star-fish (Asterias forbesii). Jas. Richardson.

32929. Long Island Sound. Killed by "hairy-whelk" (Sycotypus canaliculatus). Jas. Richardson.

32927. Long Islaud Sound. Destroyed by a whelk (Fulgur carica or Sycotypus canaliculatus). Jas. Richardson.

3151. Long Island Sound. Illustrates method of destruction by star-fish (Asterias forbesii.)

32928. Loug Islaud Sound. Destroyed by "drill" (Crosalpinx cinerea). Jas, Richardson.

32788. Crisfield, Md. Shell covered with worm tubes. E. G. Blackford.

33566. Vicinity of New York. Shell covered with worm tubes and polyzoa. E. G. Blackford.

Ravages of boring sponge. (Cliona sulphurea, Verrill.)

33591. Vicinity of South Carolina. C. C. Leslie.

33377. Oyster Bay, Long Island. H. A. Townsend.

33403. Bridgeport, Conn. Wheeler Hawley.

328:20. New York Bay, B. J. M. Carley.

32966. Long Island Sound. Hoyt Bros.

\section{Ravages of boring pholad. (Martesia cuneiformis, Gray.)}

32917. Cow Bay, Long Island. B. J. M. Carley.

33095. Rappahannock River, Virginia. G. W. Harvey.

33556. Tangier Sound. Split shells. T. W. B. Clark.

33579. Tangier Sound. Split shells in alcohol, showing pholad in situ. T. W. B. Clark.

33581. Tangier Sound. Split shells showing pholad in situ. T. W. B. Clark. 33582. Tangier Sound. Exterior of shells showing borings. T. W. B. Clark.

\section{MODEl OF AN OYSTER-BED.}

Illustrating the mamner in which a natural opster-bed is formed, the change in its condition after a period of extensive fishing, and the methods of attack of the various enemies, inhabitants of shelly areas. The vertical scale is necessarily exaggerated. Prepared by Lieut. Francis Winslow and J. Palmer. 


\section{USEFUL BIVALTES OTIIER TUAN OYSTERS.}

Mya arenaria, Linné. Long Clam, Soft-shelled Clam, or Mananose. East coast of North America from South Carolina to Aretic Ocean. Abundant from New Jersey northward; scarce south of Cape Iatteras; abundant in San Franciseo Bay, California. 32829. Canarsie Bay, Long Island. E. G. Blackford.

32955. Cape Cod, Massachusetts. E. G. Blackford.

33094. Bay of Fundy. G. F. Mathew.

33464. Ocean View, N. J. T. C. Sharp.

33474. Guilford, Conn. A. A. Foote.

*32833 (Mya Hemphillii), San Francisco Bay, California. H. Hemphill.

Mactra solidissima, Chemnitz. Hen Clam, Surf Clam, or Sea Clam. Florida and Gulf of Mexico to Labrador. Abundant from Delaware Lay to Cape Cod; in Casco Bay and Bay of Fundy. Lowwater mark to 10 fathoms.

32869. Massachusetts Bay. W. H. Dall.

Callista giganten, Chemnitz. Painted Clam. Southern coast of the United States.

3286\%. South Carolina. Dr. Wm. Stimpson.

Iracoma (sp.) Salmon Tellen.

32874. Coast of Florida. Mr. Conrad.

Cyprina istundica, Lamarek. Sea Clam. Long Island to Arctic Ocean, in soft sand or mud, at from 10 to 100 fathoms.

3350\%. Vicinity of Long Island. E. G. Blackford.

Gnathodon cuncutus, Gray. Cuneate Clam. Gulf coast, vicinity of New Orleans.

32839. Lake Pontchartrain, Louisiana. Gustav Kohn.

Ensatella Ameriedena, Verrill. Razor Fish or Razor Clam. Florida to Labrador. Common from New Jersey to Gulf of Saint Lawrence, from low-water mark to 20 fathoms.

33585. Long Island Sound. A. A. Foote.

Venus mercenaria, Linné. Quahaug or Round Clam. Abundant from Florida to Massachusetts Bay. liare and local further north on coast of Maine, Nova Scotia, and southern shore of Gulf of Saint Lawrence. Not found on coast of Maine east of liennebee River, nor in Bay of Fundy. The shells of Venus mercenaria vary so much in color and character that a number of distinct species have been described. The variations, however, are, like those of the oyster, by no means constant, and are due, irineipally, to the character of bottom and water. In the following series, four varieties are shown, with the intermediate types connecting them.

\footnotetext{
* Transplanted from the east by accident, with young oysters.
} 
Purple-shelled rariety: Exterior of shell smooth and discolored; interior more or less purple tinted about margin.

32817. Rockaway, Long Island. B. J. M. Carley.

32862. Dr. Wm. Stimpson.

32877. Dr. Wm. Stimpson.

33404. Oyster Bay, Long Island. Soft bottom. H. A. Townsend.

33419. Narragansett Bay, Rhode Island. A. A. Wilson.

33428. Ocean View, N. J. Two to three years old. T. C. Sharp.

33509. Lake's Bay, N. J. Muddy bottom. Five years old. Alex. Fish.

33560. Barnegat, N. J. Allan Neill.

White-shelled rariety: Exterior, rough, with high, thin concentric ribs; interior, white.

32862. Dr. Wm. Stimpson.

32838. Barataria Bay, Louisiana. Gustav Kobn.

33404. Osster Bay, Long Island. Soft bottom. H. A. Townsend.

33405. Seaville, N. Y. J. W. Gandy.

32818. New York. B. J. M. Carley.

33446. East Greenwich, R. I. A. A. Wilson.

33478. Somers Point, N. J. H. H. Vansant.

33560. Barnegat, N. J. Allan Neill.

Intermediate: Exterior, rough; interior, purple tinted.

32862. Dr. Wm. Stimpson.

33478. Somers' Point, N.J. H. H. Vansant.

32877. Dr. Wm. Stimpson.

33428. Ocean View, N. J. Two to three years old. T. C. Sharp.

33472. New Rochelle, N. Y. A. A. Foote.

33404. Oyster Bay, Long Island. Soft bottom,

3:3560. Barnegat, N. J. Allan Neill.

Intermediate: Exterior, smooth; interior, white.

33472. Ner Rochelle, N. Y. One to four years old. A. A. Foote.

32877. Dr. Ww. Stimpson.

33560. Barnegat, N.J. Allan Neill.

33478. Somers Point N. J. H. H. Vansant.

33404. Oyster Bay, Long Island. Soft bottom. H. A. Townsend.

33421. East Greenwich, R. I. A. A. Wilson.

33446. East Greenwich, R. I. A. A. Wilson.

Elongated variety:

33405. Seaville, N. J. J. W. Ganily.

32817. Rockaway, N. J. B. J. M. Carley.

Snub-nosed rariety:

32862. Dr. Wm. Stimpson.

33419. Narragansett Bay. A. A. Wilson.

32819. Fire Island, Long Island. B. J. M. Carley.

Mytilus clulis, Linné. Edible mussel. Arctic Ocean south to North Carolina on the eastern coast, and to Monterey on the Pacifie coast of the United States. Abundant from New Jersey northward.

33349. East Greenwich, R. I. A. A. Wilson.

33583. Stony Creek, Loug Island Sound. A. A. Foote.

33629. Vineyard Sound. U. S. Fish Commission. 
Modiola plicatuld, Lamarck. Grooved mussel. Georgia to Caseo Bay, Maine; more rare and local further north. Abundant from New Jersey to Massachusetts.

33596. Coast of New Jersey. U. S. Fish Commission.

33486. Ocean View, N. J. T. C. Sharp.

3345\%. East Greenwich, R. I. A. A. Wilson.

Modiola modiolus, Turton. Horse Mussel. Greenland sonth to New Jersey on the eastern coast and south to Monterey on the Pacific coast of the United States. Abundant north of Cape Cod, and about Long Island and Staten Island.

33662. Georges Bank. R. H. Hurlburt.

33608. Vicinity of New York. E. G. Blackford.

34643. Stones, shells, \&c., attached by byssus. E. G. Blackford.

Pecten irradians, Lamarek. Seallop. Florida and northern shores of the Gulf of Mexico to Cape Cod. Rare and local further north. Abundant from Long Island Sound southward.

33608. Great South Bay, Long Island. F. C. Dayton.

\section{East Greenwich, R. I.}

33567. Series illustrating color variations. A. A. Wilson.

\section{SERIES ILLUSTRATING GROWTH.}

33431. Size during first week in September.

33432. Size during second week in September.

33433. Size during third week in September.

33434. Size during fourth week in September.

23435. Size during first week in October.

33436. Size during second week in October.

334:37. Size during third week in October.

33438. Size during fourth week in October.

33439. Size during first week in November.

33440. Size duriug second week in November.

33441. Size during third week in November.

33442. Size during fourth week in November.

33443. Size when about one year old-marketable.

33444. Size when fifteen months old.

33445. Size when twenty-seven months old (very rare).

Pecten temuicostatus, Mighels. Great or Giant Seallop. New Jersey to Labrador. Rare and local south of Cape Cod. Abundant in Frenchman's Bay, Mount Desert. Common in Massachusetts and Casco Bays and Bay of Fundy.

33631. Cape Cod, Massachusetts. U. S. Fish Commission.

32979. Castine, Me. Showing ravages of boring sponge (cliona sulphurea).

A. R. Crittenden.

32950. Castine, Me. Showing ravages of boring sponge (Cliona sulphurea).

L. J. Heath.

Argina pexata, Gray. Bloody Clam. Florida and northeru shores of the Gulf of Mexico to Cape Cod. Rare and local further north. Abundaut from New Jersey to Massachusetts. 33570. Maurice River Cove, Delaware Bay. Thos, J. Love. 33460. East Greenwich, R. I. A. A. Wilson. 
Glycimeris generosa, Gould. Georluek or Giant Clam. Pacifie coast, in rivers and estuaries, from Puget Sound to San Diego. Not common as southern limit is approached, nor very abundant at any point.

33614. California coast. R. E. C. Stearns.

33615. California coast. R. E. C. Stearns.

Siliqua patula, Dixon. Razor Clam. From Vanconver's Island to San Diego. Coast of California. Abundant in Oregon and Washington Territory and adjacent islands.

32881. W. H. Dall.

Semele decisa, Cpr. Flat Clam. San Diego and California coast. 32847. San Diego, Cal. H. Hemphill.

Platyodon cancellatus, Conrad. Date Fish. San Diego, Santa Barbara, and San Francisco, Cal. Coast of California. 32850. Baulinas Bay. H. Hemphill.

Zirphece erispata, Möreh. Date Fish. Northwest coast of Ameriea to California, Puget Somnd, Vancouver Island, San Diego, and San Pedro.

32556. Baulinas Bay. H. Hemphill.

33641. R. E. C. Stearns.

Ilacoma nasuta, Conrad. Tellen. Kamschatka to San Diego, Cal. Iittoral, 3 teet in mud.

32848. San Francisco market. H. Hemphill.

Saxidomus aratus, Gould. Round Clam. San Francisco Bay and San Diego, Cal.

32843. San Diego, Cal. H. Hemphill.

Chione succincta, Valeneiennes. Little Neck Clam. Coast of California. 32841. San Diego, Cal. H. Hemphill.

Chione simillima, Sowerby. Little Neck Clam. San Francisco to San Diego, Cal.

32842. San Diego, Cal. H. Hemphill.

Tapes staminea, Courad. Little Neck Clam. Coast of California. Littoral, 2 feet in mud.

:32854. Baulinas Bay, California. H. Hemphill.

32844. Tomales Bay, California. H. Hemphill.

Tapes laciniata, Cpr. Little Neck Clam. Monterey and San Diego, Cal.

32846. San Diego, Cal. H. Hemphill. 


\section{USE OF ORNAMENTAL BIVAIVES OTHER THAN THOSE AFFORDING FOOD.}

\section{Pearl-producing.}

\section{Unionida.}

Unio (various sp.). River Mussels. Fresh water streams of the United States. Abundant in the rivers of the Western States.

25986 to 26010 . Series having both valves polished. From Dr. C. A. Miller,

Cincinnati, Ohio. Comprises the following species:

Unio metanevrus, Rafinesque.

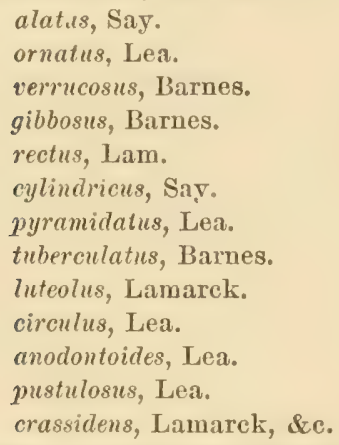

2609:a. Kiver mussel affording pearl-shell, illustrating application of raw material. Cincinnati, Ohio. D. Shaffer.

26092. Carvings, from pearl-shell afforded by river mussels, for use as studs, buttons, pins, brooches, \&c. Cincinnati, Ohio. D. H. Shaffer.

26092b. Pearls derived from river mussels. Cincinnati, Ohio. D. H. Shaffer.

\section{Aviculide.}

MLargaritiphora fimbriata, Dkr. Pearl Oyster. Head of Gulf of California to Panama. Common in the region of La Paz, Lower California, and in vicinity of Panama.

13507. Colonel Jervett.

3624. Illustrating formation of pearls. Panama. Colonel Jerrett.

32836. Gulf of California. J. Xantus.

--. Polisher shell. Chicopee, Mass. Jas. T. Ames.

32921. Made into artificial fish-bait. Boston, Mass. Bradford \& Anthony.

32922. Made into artificial minnow. Boston, Mass. Bradford \& Anthony.

-. Series of buttons, studs, stopper-eaps, \& c. Manufactured from, and showing application of, American pearl-oyster shell. Furnished by A. B. De Frece \& Co., 428 Broadway, New York.

\section{Otherwise useful and ornamental.}

Composition shell-work for box-covers and frames, made by ghuing shells in mosaic.

29527. Basket. Made from Florida shells. E. F. Gilbert, Jacksonville, Fla.

22210. Basket. Made from Florida shells. Mrs. Mott, Jacksonville, Fla. 22209. Frame. Made from Florida sea-shells. Mrs. C. E. Mott, Jacksonville, Fla.

22211. Easter Cross. Made from Florida shells. Mrs. Mott, Jacksonville. 
20526. Shell flowers. Made from Florida shells. E. F. Gilbert, Jacksonville. Fla.

32869. "Hen Clam" (Mactra solidissima Chem). Painted inside and nsed for catch-alls.

32840. Cuneate clam (Gnathodon cuneatus). Semi-fossil (in shell heaps); used for macadamizing roads. Lake Salvador, Louisiana. Gustav Kohn.

\section{Injurious bivalves.}

\section{Tereilo. SHIP-WORM.}

T. navalis, Limné. Florida to Vineyard Somnd. T. megotara, Ianley. Massachusetts to South Caroliua. T. Thomsonii, Tryou. Massachusetts and Buzzard's Bay. T. dilatata, Tryon. Massachusetts to South Carolina. Tylotrya fimbriate, Jefleys. Long Island to Florida.

Specimens of wood showing ravages.

32982. Bangor, Me. (Brig H. B. Emory.) C. H. Parker.

32908. In lignum-vitæ wood. Gloucester, Mass. Samuel Elıell, jr.

33106. (Teredo chlorotzea, Gld.) Wood's Holl, Mass. Vinal N. Edwards.

33105. (Xylotrya fimbriata, Jeffr.) Wood's Holl, Mas8. Vinal N. Edwards.

32934. (Teredo navalis? L.) New Haven, Conn. A. E. Verrill.

32902. (Teredo sp.) Showing damage effected in white-pine wood in one year. Pier 44, North River, N. Y. W. T. Pelton.

32901. Showing damage to hard-pine wood effected in one year. Charleston, S. C. W. T. Pelton.

3:983. Schooner Carrie Melvin; done in six weeks. Charleston, S. C. A. G. Hunt.

32815. (Teredo sp.). Gulf coast. Dewey.

32816. Showing lining of tubes. Texas. Dr. Schott.

19405. (Xylotrya sp.) Coast of Oregon. J. G. Swan.

33616. (Teredo sp.) Showing ravages in six weeks. Indian River, Fla. G. S. Hobbs.

33617. (Teredo sp.) Showing ravages in three months. Indian River, Fla. G. S. Hobbs.

33638. (Teredo sp.) Wood showing ravages. U. S. Fish Commission.

33630. Teredo megotara. Hanley. Off Martha's Vineyard. (Specimens in alcohol.) U. S. Fish Commission.

Martesia cuneiformis, Gray. Boring pholad. Sonthern coast of the United States to New Jerses. Rare and local futher north, and in Long Island Sound. Abuudant on oyster-beds of Chesapeake Bay.

33580. Tangier Sound, Maryland. T. W. B. Clark.

(For illustration of ravages, see oyster section, "Ravages of enemies.")

Enemies other than mollusea, inhabiting oyster-beds and destructive to shellfish.

Panopers Sayi, Smith. Mud Crab.

36:8. Off Martha's Vineyard. U. S. Fish Commission.

(See Section, Crustaeea, Echinoderms, \&c.) 
Cuncer imoratus, Say. Rock Crab.

3630. Vineyard Sound, U. S. Fish Commission.

(Seo Section, Crustacea, Echinoderms, $\oint c$.)

Carcinus .Menas, Gould. (C'urcinus granulutus, Say.) Green Crab.

3627. Vineyard Sound. U. S. Fish Commission.

(See Section, Crustacea, Echinoderms, \&c.)

For other crabs see Section, Crustacca, echinoderms, de.

Asturas Forbesii, Verrill. (Asterias arenicola, Stimusom.) Green Starfish.

5559. Vineyard Sound. U. S. Fish Commission.

(See Section, Crustacea, Echinoderms, \&c.)

MLicrociona prolifera, Verrill. Red, Branching Sponge.

531. Wood's Holl, Mass. U. S. Fish Commission. (Not directly injurious.)

(See Section, Crustacea, Echinoderms, \&c.)

Clione sulphurea, Verrill. Boring Sponge.

1010. Vineyard Sound. U. S. Fish Commission.

(See Section, Crustacea, Echinoderms, \&c. For ravages, seo oyster section,

"Ravages of enemies.")

Archosargus probatocephahus (Walb.) Gill. Sbeepshead.

See "Fishes." Family Sparida.

Pogonias chromis, Lacep. Drum.

See "Fishes." Family Scianida.

\section{COMMENSAL.}

Pinnotheres ostreum, Say. Oyster Crab. Commensal with southern oysters and with northeru in rivers where southern oysters have been long planted.

4991. New York market. E. G. Blackford.

Pimnothere's maculatus, Say. Commensal with edible mussel (Mytilus calis) and Great Scallop (Pecten tenuicostatus).

For specimen see Section, Crustacea, Echinoderms, dc.

\section{SHELL-FISH FISHERY.}

\section{VESSELS AND BOATS.}

55804. Model of an oyster schooner. Chesapeake and Delaware Bay type. Used in dredging oysters. U.S. Fish Commission.

26536. Model of an oyster schooner. (Scale, 1 inch to the foot.) Chesapeake and Delaware Bay type. Used in dredging oysters. T. B. Ferguson.

25002. Model of a Chesapeake canoe-pungy. (Scale, 1 inch to the foot.) Used in dredging oysters. 'T. B. Ferguson.

55807. Model of an oyster pinkie. U. S. Fish Commission.

42758. Model of a Chesapeake oyster-pungy. 'T. B. Ferguson. 
25003. Model of a Chesapeake oyster-canoe. (Scale, 1 inch to a foot.) Made from two logs and used in "tonging" oysters in Chesatpeake Bay. T. B. Ferguson.

22217. Model of a fishing boat used by Chinese fishermen on the Pacific coast in shell-fishery. Livingstone Stoue.

22213. Model of a tishing boat used on the Pacific coast in the shell-fishery. Livingstone Stone.

25057. Model of a Nantucket dory. (Scale, 1 inch to the foot.) Used in gathering clams for bait. W. H. Chase.

12678. Hodel of a New England dory. (Scale, 1 inch to the foot.) Used in gathering and transplanting clams. Starling \& Stevens, Ferryville, Me.

24752. Model of a Connecticut sharpie. (Scale, 1 inch to the foot.) Used in the oyster and scallop fisheries of Long Island and Long Island Sound. H. C. Chester.

29537. Model of Providence River cat-boat. Used in scallop fishery. J. M. K. Southwick.

Crayon showing elamming dories on the beach. U. S. Fish Commission.

- Crajon showing Connecticut steam oyster-dredger "W. H. Lockwood," at work off New Haven. U. S. Fish Commission.

The types, such as cat-boats, rories, sloops, and small schooners, used along the New England coast in the seine and line fishing, are also employed indiseriminately in the shell-fish fisheries, especially those of the oyster and scallop. In Long Island Somnl, of late years, these cratt have been superseder, howerer, to a great extent, by the steam dreedying vessels. For other models see Industrial Lishibit.

\section{IMPLEMTENTS.}

57570. Oyster dredge used by Connecticnt steam oyster dredgers. When of this size but two are used, one on each side of the vessel. With smaller sizes, four are operated at the same time. C. D. Hall.

57089. Oyster dredge with teeth. Style in general use in Chesapeake and Delaware Bays. U. S. Fish Commission.

57090. Oyster scrape without teeth. Style in general use in Chesapeake and Delaware Bays, in shallow water and on soft bottom. U.S. Fish Commission.

31792. Model of an oyster dredge, and patent "winder." Showing method of operating the dredging apparate's. C. S. Belbin.

57092. Improved "winder" or windlass for hauling in oyster dredges. U. S. Fish Commission.

57693. Oyster tongs, 10 -foot handles and 10 teeth. Galvanized iron frame. U. S. Fish Commission.

57694. Oyster tongs, 10 -foot handles and 10 teeth. Galvanized iron frame. U. S. Fish Commission.

26110. Oyster tongs, 8-foot handles and 12 teeth. Head of wood, frame of small brass rods. S. Salisbury.

26109. Oyster-tongs. 8-fuot handle and 8 teeth. Head of wood, frame of small brass rods. S. Salisbury.

25205. Oyster-tougs. 8-foot handle and 10 teeth. Frame, head, and teeth of galvanized iron. Wilcox \& Crittenden.

29111. Oyster-nippers. 8-foot handle and 3 teeth, $2 \frac{1}{2}$ inches long. S. Salisbury. 
57806. Model of oyster-tongs. W. P. Haywood.

57557. Scallop-dredge, Narragansett Bay. For use on hard bottoms. A. A. Wilson.

57558. Scallop-dredge, Narragansett Bay. "Slider" style; for use on grassy bottoms. A. A. Wilson.

57559. Scallop-dredge, Narragansett Bay. "Ketlle-bail" style; for use on muddy bottoms. A. A. Wilson.

57087. Scallop-dredge, New Bedford. Old style with twine net. J. T. Brown.

57088. Scallop-dredge, New Bedford. New style, with iron-mesh net. J. T. Brown.

57091. Clam rake. Provincetown, Mass., style. Used in taking sea-clams. (Mactra solidissima.) J. T. Brown.

57695. Clam rake. Nantucket style. 13-foot pole, 23 teeth, twine net. Used in taking sea-clams. (Mactra solidissima.) U. S. Fish Commission.

29466. Clam hoe. Provincetown, Mass. Wm. H. Hesbolt.

29437. Hand-claw. Used for gathering "hen" clams and scallops. Wellfleet, Cape Cod, and coast of Maine. M. W. Grant.

36043. Clam rake. 23-foot pole, 16 teeth 6 inches long. Used in taking "quahaugs" (Venus mercenaria) and "hen" clams. (Lactra solidissima.) U. S. Fish Commission.

36040. Clam rake. 18-foot pole, 16 teeth 6 inches long. Used in taking "quahaugs" ( Venus merceneria) and "hen" clams. (Hactra solidissima.) U. S. Fish Commission,

36045. Clam rake. Wellfleet style. U. S. Fish Commission.

36046. Clam rake. Welltleet style. 5-foot handle, 13 teeth, 5 inches long. Used in taking "quahaugs" (Venus mercenaria.) U. S. Fish Commission.

36047. Clam rake. Wellfleet style. 5 foot handle, 17 teeth 6 inches long. Used in taking "quahaugs" (Venus mercenaria.) U. S. Fish Commission.

- Clam rake (model) used in collecting sea-clams. (See model of Nantucket dory.)

- Osster shovel (model). (See model of Chesapeake oyster canoe.)

The moss rakes, large and small, and rarious agricultural implements fuch as spakles, shovels, hoes, Ece, are used in taking clams and other shell-fish; but they are not exhibited in this section.

\section{OYSTER CULTIVATION.}

Trating of the offrial map of the Shell-Fish Commissioners of the State of Iilode Island, showing loeation of oyster-farms in the Providence River and Narragansett Bay, and illustrating the methods emyisped in assigning poutions of the bottom for orster cultivation, and in mantaining the buoys and marks in proper position. Seale roưo. Index plan of the above. Scale $\frac{1}{80000}$.

Cony of the oficial map of the Shell-Fish Commissioners of the State of Connecticut, showing the natural beds, the area under cultivation, and the area designated or applied for but not yet improved; and illustrating the system adopted by the State of Comnectient for the purpose of encouraging the oyster industry. 
Copy of the the triangulation sheet of the Connecticut commission. Contributed by the shell-fish commission of the State of Connecticut.

Copy of the map of the town commissioners of Patchogue, Long Island, showing the oyster-farms and areas belonging to the various oyster companies and oyster associations of Great South Bay, Long Island.

For laws and regulations governing oyster-farming in the foregoing localities, see

"Introduction" and reports of commissioners in the collection of publications.

\section{METHODS OF PRESERVING AND TRANSPORTING SHELL- FISH.}

Models of the apparatus used in "steaming" oysters, including the following articles:

Tram-car of iron, on iron wheels, for holding oysters while in steamchest, and transporting them thence to the opening room.

Steam-chest of oak, lined with iron and fitted with appliances for admitting steam when doors are closed. Doors movable vertically and close fitting.

Iron tracks for car.

Turn-table ior car.

Tin pot fitted to hook to side of car and into which the oysters are put as soon as opened.

Sieve in which the oysters are put for washing after reception from openers.

Table upon which the oysters are placed after washing and where the cans are filled and weighed.

Crate or basket, circular in form and of iron, into which the cans are piled, regularly, after being filled. Models of cans shown in position.

Dray for transporting cans.

Derrick for raising crates in transporting them from process-kettle to cooling-tub.

Process-kettle, circular, of iron, lid closing hermetically, and fitted with steam-pipes and thermometer. In the course of preparation the crates containing the cans of oysters are placed in the kettle, the lid closed, and the steam turned on.

Cooling-tub, of wood, containing cold water. The crates with contents are transferred to this tub, after steaming, in order to cool them.

Capping-table. The cans are transferred to this table, from the cooling-tub, and there have the caps soldered on.

Capping-iron (natural size). This is an arrangement of an ordinary soldering iron, so as to facilitate the soldering of the cans. 
Models of the apparatus used in opening and packing oysters.

Shucking trough, with stand for workman, hammer, knife, block, two buckets; one to receive small oysters, the other for "selects."

Skimmer and gallon pot for receiving oysters from the shuckers.

Three tubs, one to receive small oysters, one for "selects," and one holding water.

Cullender in which the oysters are washed.

Shake-bucket for transferring oysters to and from tubs.

Table holding the eans to be filled.

Dipper for holding water.

Cup for holding oysters.

Cup for holding water.

Funnel for filling cans.

Case in which cans are packed for shipment.

Implements used-natural size.

Set of measuring cups.

"Dipper."

Set of funnels.

Shake-bucket.

Gallnn pot.

Hammer.

Knife.

Shucker's buckets.

Block.

Case containing eans. A. Booth \& Co., Baltimore, Maryland.

Oyster tubs and buckets used in transporting shell-fish. W. S. Robinson \& Co., New Haven, Connecticut.

Oyster-tubs used in the Western States in transporting oysters. Mann Bros., Chicago, Illinois. 



$$
65131
$$

